UNIVERSIDADE DE BRASÍLIA

PROGRAMA DE PÓS-GRADUAÇÃO EM HISTÓRIA - PPGHIS

Mariana Lima Barcelos

\title{
Entre conflitos e mediações: a formação da Câmara de Vila Rica (1711-1736)
}




\section{Entre conflitos e mediações: a formação da Câmara de Vila Rica (1711-1736)}

Dissertação apresentada ao Programa de Pósgraduação em História do Instituto de Ciências Humanas da Universidade de Brasília como parte dos requisitos necessários para a obtenção do grau de mestre em História Social.

Orientadora: Prof. Dra. Teresa

Cristina de Novaes Marques

Brasília - DF

DEZEMBRO DE 2014 
Nome: BARCELOS, Mariana Lima

Título: Entre conflitos e mediações: a formação da Câmara de Vila Rica (1711-1736)

Dissertação apresentada ao Programa de Pósgraduação em História do Instituto de Ciências Humanas da Universidade de Brasília como parte dos requisitos necessários para a obtenção do grau de mestre em História Social.

Aprovado em:

Banca Examinadora

Prof. Dra. Teresa Cristina de Novaes Marques

Instituição: UNB

Julgamento:

Assinatura:

Prof. Dr. Tiago Luís Gil

Instituição: UNB

Julgamento:

Assinatura:

Prof. Dr. Kelerson Semerene Costa

Instituição: UNB

Julgamento:

Assinatura: 


\section{AGRADECIMENTOS}

Em primeiro lugar agradeço a minha orientadora, Prof. Teresa Cristina de Novaes Marques, por ter me apoiado desde a graduação e confiado na minha dissertação. Sou grata também ao prof. Tiago Luís Gil que me ajudou a me manter no FOCO que um mestrado requer. Agradeço ao Programa de Pós-Graduação em História da Universidade de Brasília e aos departamentos de História da Universidade de Brasília e da Universidade Federal de Ouro Preto por me ensinarem o ofício do historiador. Sou grata ao Jorge e ao Rodolfo por tornarem os trâmites burocráticos da pós-graduação mais amenos.

A prof. Neuma Brilhante, agradeço pelas importantes contribuições durante a banca de qualificação. Ao prof. Marcos Aurélio Pereira, sou grata não só por seus conselhos na banca de qualificação mas também pelas sugestões de bibliografia dadas nos encontros pelos corredores do departamento de história da Universidade da Brasília nos últimos três anos. Sou grata aos professores Marcelo Balaban, Diva Muniz, Tereza Kirchner e Arthur Assis por terem me ajudado, cada um a sua maneira, durante as disciplinas do mestrado.

Agradeço à Coordenação de Aperfeiçoamento de Pessoal de Nível Superior (CAPES) pelo apoio financeiro a esta dissertação. Sou grata também aos arquivos da Casa Setecentista de Mariana, Casa dos Contos de Ouro Preto e Arquivo Público Mineiro por me auxiliarem no emaranhado de documentos pesquisados para esta dissertação. Ao meu tio Eduardo, a Rita, a Isabela e Isadora por me recepcionarem de braços abertos em todas as viagens que fiz as Minas durante esse caminho.

A minha mãe, sou grata por sempre me apoiar, com seu carinho e atenção, e também por revisar todos os meus textos desde a graduação. Agradeço ao meu pai que, mesmo estando longe, sempre apoiou todos os meus projetos de vida. Agradeço a minha tia Ivanildes por ter assumido a incumbência de me criar com todo seu amor e zelo. Sou grata aos meus irmãos Rodrigo e Maria Clara. À Debora, por ser muito mais que uma madrasta, uma amiga. Agradeço aos meus animais de estimação por me fazerem companhia durante toda escrita da dissertação e por me fazerem sorrir a cada estripulia. Sou grata a toda minha família.

Agradeço a todos os habitantes da sala do Casadinho na BCE por me fazerem rir nas horas mais complexas. Ao David por ler meus textos e me tranqüilizar nos momentos difíceis. As minhas lindas amigas mestras Marina, Renata e Walkíria por tornarem o mestrado 
divertido e menos tortuoso. A todos os meus colegas de mestrado sou grata por tornarem cada disciplina mais fácil.

De modo geral, agradeço a todos os meus amigos que compreenderam a minha constante ausência nos últimos três anos e que sempre se preocuparam comigo. À Dani e à Luísa, por me acompanharem desde a graduação. Ao Luiz Antônio, ao Seu Luís e ao Jeferson, por estarem sempre do meu lado mesmo fora da tutoria do PPNE. Ao Franklin por ser um grande amigo e me fazer rir sempre que pode.

Em especial, meu agradecimento a Tomás Verdi Pereira, meu companheiro nas horas de alegria e de tristeza. Palavras não conseguem descrever o quanto eu sou grata a você, meu amor. A família do Tom que me deu suporte durante o mestrado. Sem vocês minhas caronas para Universidade de Brasília seriam menos divertidas. 


\section{RESUMO}

Esta dissertação busca analisar como ocorreu a formação da Câmara de Vila Rica e sua atuação na região mineradora entre 1711 e 1736. Em Portugal, as câmaras eram espaços de representação da elite local. Além disso, as municipalidades portuguesas eram responsáveis pela normatização da vida política e administrativa das regiões sob sua jurisdição. Durante a colonização da América Portuguesa, essa instituição foi transladada para o ultramar, adquirindo novas características e atribuições de acordo com as necessidades do cotidiano colonial. Nas Minas, as câmaras se constituíram em um espaço, ora de mediação dos interesses régios e da população, ora de contestação às ordens régias. Para tanto, utilizei um conjunto diversificado de documentos (correspondências entre autoridades, atas da Câmara da Vila Rica e escritos de viajantes coevos) para estudar a atuação política da municipalidade Vilariquenha. Por meio da história da constituição da Câmara de Vila Rica nas Minas procuro problematizar como a organização política e administrativa portuguesa se instalou lentamente na região mineradora na primeira metade do século XVIII.

Palavras-chave: câmaras, municipalidades, administração colonial, paulistas, emboabas, Levante dos Emboabas, Câmara de Vila Rica, Sedição de Vila Rica de 1720. 


\begin{abstract}
This thesis aims to analyze the establishment of the Chamber of Vila Rica ("Câmara de Vila Rica") and its role in the mining region between 1711 and 1736. In Portugal, chambers ("câmaras") were spaces of representation of the local elite. Besides this, Portuguese municipalities were responsible for the standardization of the political and administrative scenario of the regions under their jurisdiction. During the colonization of Portuguese America, this institution was transferred to the newly discovered lands, acquiring new characteristics and attributions according to the needs of day-to-day life in the colony. In Minas ("Mines"), these chambers comprised a space used at times for monitoring the interests of the Crown and the population, and at others for challenging royal orders. For this, I used a wide range of historical documents (letters between officials, minutes made at the Chamber of Vila Rica and writings by travelers of the time) in order to study the political role of the municipality of Vila Rica. By analyzing the formation of the Chamber of Vila Rica, I aim to discuss how the Portuguese political and administrative organization settled gradually over the first half of the $18^{\text {th }}$ century.
\end{abstract}

Keywords: chambers, municipalities, colonial administration, paulistas, emboabas, Emboaba Rebellion, Chamber of Vila Rica, 1720 Sedition of Vila Rica. 


\section{ABREVIATURAS}

AHU - Arquivo Histórico Ultramarino

APM - Arquivo Público Mineiro

CMOP - Câmara Municipal de Ouro Preto 


\section{SUMÁRIO}

INTRODUÇÃO ............................................................................................................10

FORMAÇÃO DAS MINAS E O LEVANTE DOS EMBOABAS.................................21

1.1. OS PRIMEIROS ACHADOS E A OCUPAÇÃO DA REGIÃO MINERADORA ............................22

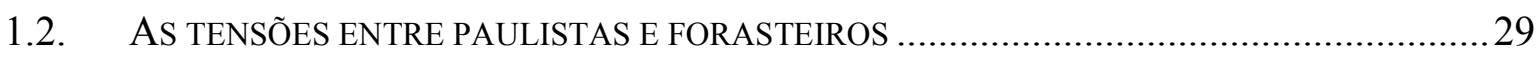

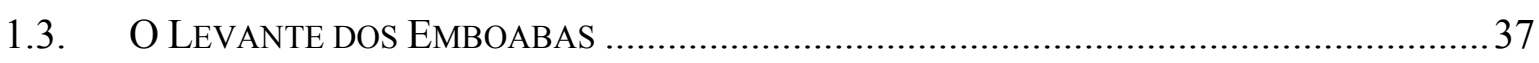

A CÂMARA DE VILA RICA E A SEDIÇÃO DE 1720 ............................................48

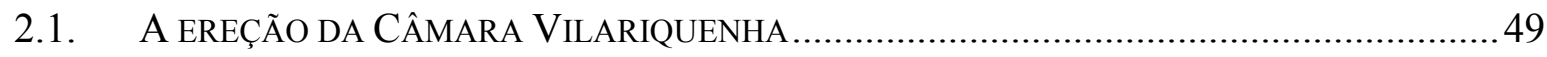

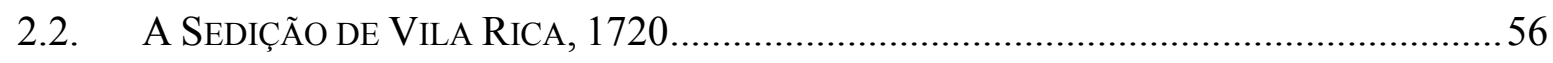

2.3. O GOVERNO DE D. LOURENÇO DE AlMEIdA E A PACIFICAÇÃO DAS MinAS ...............68 ENTRE CONFLITOS E MEDIAÇÕES - A ATIVIDADE CAMARÁRIA NAS MINAS .72

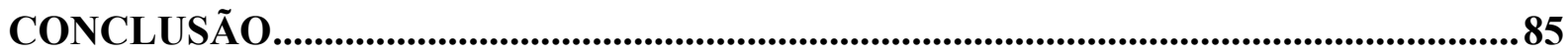

FONTES E REFERÊNCIAS BIBLIOGRÁFICAS...........................................................88 
INTRODUÇÃO 
Esta dissertação tem como objetivo estudar as relações de poder existentes nas Minas no início do século XVIII, por meio da municipalidade de Vila Rica. As câmaras no ultramar foram espaços que possibilitaram a representação política dos homens bons das vilas ${ }^{1}$. Também as municipalidades serviram como elo entre a Coroa e seus vassalos do além-mar.

Para o Estado luso, a constituição das municipalidades era importante porque as câmaras reforçavam simbolicamente o poder da Coroa na América portuguesa. As municipalidades também foram responsáveis por conduzir o processo de instalação das estruturas do Estado português no ultramar ${ }^{2}$. Portanto, estudar as câmaras na América portuguesa é enriquecedor para entender como se deu o processo gradual da organização política e administrativa portuguesa na colônia.

As municipalidades nas Minas foram estabelecidas pela Coroa com o objetivo de normatizar o cotidiano da sociedade mineradora e reforçar a presença simbólica e política do Estado português na região. No entanto, muitas vezes, as municipalidades nas Minas se tornaram espaços privilegiados para a contestação do poder régio. Concomitantemente, o poder local das câmaras foi rechaçado pela população em diversos momentos. Através das câmaras podemos estudar várias camadas da estrutura de poder presente na região mineradora no início do século XVIII.

A atual proposta de investigação procura contribuir para a produção da história política do Brasil Colônia e das Minas, ao analisar as práticas políticas da Câmara de Vila Rica no início do século XVIII. Tal estudo visa colaborar também com uma série de possibilidades investigativas como: os diferentes estilos de governantes, as práticas políticas nas Minas e o imaginário político da região.

Enveredando-se por uma abordagem política das municipalidades nas Minas setecentistas, a proposta de trabalho pretende aprofundar nos estudos do campo da História política, seguindo a abordagem da Nova História Política ${ }^{3}$. O conceito de política é tratado de forma ampliada, abarcando não só o Estado, mas também outras dimensões da realidade. As

\footnotetext{
${ }^{1}$ BICALHO, Maria Fernanda Bicalho. As Câmaras Municipais no Império Português : o exemplo do Rio de Janeiro. Revista Brasileira de História, São Paulo, v. 18, n.36, p. 251-280, 1998. ${ }^{2}$ Ibdem.

${ }^{3}$ FALCÓN, FRANCISCO. História e Poder. In CARDOSO, Ciro Flamarion S; VAINFAS, Ronaldo (Coord). Dominios da historia: Ensaios de teoria e metodologia. Rio de Janeiro: Campus, 1997.
} 
relações estabelecidas dentro do campo político estão em permanente interação com a sociedade ${ }^{4}$.

A investigação também procura somar-se aos estudos já realizados sobre a Câmara de Vila Rica no início do século XVIII. Existe uma variedade de trabalhos sobre o assunto. Todavia, não há um estudo específico para Câmara de Vila Rica que abarque o campo político e as formas de negociação.

Trabalhos elaborados anteriormente apenas perpassam o tema, mas estão centrados na análise, por exemplo, do espaço urbano ${ }^{5}$, da estrutura de posse dos camarários $^{6}$ ou da realização de festas e cerimônias religiosas ${ }^{7}$. Há uma gama de possibilidades que o tema oferece. Empreender um estudo especificamente sobre a Câmara de Vila Rica, utilizando um viés político, só vêm a colaborar para produção da História das Minas Setecentistas.

Revisão bibliográfica

A presente revisão bibliográfica procura elencar os trabalhos mais importantes para o andamento da pesquisa. Busquei destacar as obras após a década de 1990 porque neste período ocorreu uma mudança interpretativa significativa sobre as formas de pensar a administração portuguesa ultramarina.

A partir da década de 1990, a produção historiográfica no Brasil passou por diversas mudanças. Autores como Carla Anastasia $^{8}$ e Maria Fernanda Bicalho ${ }^{9}$ investigaram respectivamente os conflitos nas Minas e as relações de poder nas câmaras no ultramar partindo da perspectiva dos colonos.

\footnotetext{
4“[...] os contornos da política não estão dados a partir dela própria, como, aliás, ocorre em todas as dimensões da vida humana. É na complexa teia de relações sociais que configura um período ou processo histórico que podemos encontrar e definir tanto as formas de poder e cristalização quanto os movimentos que, aberta ou discretamente, envolvem conflitos e disputas por ele." MENDONÇA, Sônia Regina de; FONTES, Virgínia. História e Teoria Política. In CARDOSO, Ciro Flamarion; VAINFAS, Ronaldo (Org.). Novos domínios da História. 1. ed. Rio de Janeiro: Campus-Elsevier, 2011, p. 61.

${ }^{5}$ BORREGO, Maria Aparecida de Menezes. Códigos e práticas : o processo de constituição urbana em Vila Rica colonial (1702-1748). São Paulo: Annablume, 2004.

${ }^{6}$ FIORAVANTE, Fernanda "Às custas do sangue, fazenda e escravos": formas de enriquecimento e padrão de ocupação dos ofícios da Câmara de Vila Rica, c. 1711 - c. 1736. Rio de Janeiro: UFRJ, PPGHIS, 2008.

${ }^{7}$ SANTIAGO, Camila Fernanda Guimarães. Vila Ricas em festas: as festas promovidas pelo Senado da Câmara de Vila Rica (1711-1744). Belo Horizonte: UFMG, 2001.

${ }^{8}$ ANASTASIA, Carla Maria Junho. Vassalos Rebeldes: violência coletiva nas Minas na primeira metade do século XVIII. Belo Horizonte: C/Arte, 1998.

${ }^{9}$ BICALHO, Maria Fernanda Bicalho. As Câmaras Municipais no Império Português : o exemplo do Rio de Janeiro. Revista Brasileira de História, São Paulo, v. 18, n.36, p. 251-280, 1998.
} 
Questionando a tradicional divisão das revoltas coloniais em emancipacionistas e nativistas, Carla Maria Junho Anastasia procurou investigar os motins nas Minas da primeira metade do século XVIII ${ }^{10}$. Analisando o poder de aplicação da autoridade régia, considerando as tradições locais, a autora desenvolveu uma classificação para as rebeliões nas Minas.

Segundo Anastasia, os motins podiam ter um caráter de manutenção das regras estabelecidas desde o início da mineração, ou seja, dentro das regras do jogo; ou, um caráter de fragmentação da soberania metropolitana, por não atender aos interesses locais; ou um caráter duplo, no qual encontramos as duas características. Com essa tipologia, a autora buscou mudar a visão dicotômica de contestação versus oposição, sob a argumentação de que este entendimento desconsidera a dinâmica interna colonial. O trabalho de Carla Anastasia constitui um avanço para os estudos da cultura política nas Minas porque não trata as relações entre Portugal e o ultramar de forma dicotômica. Todavia, a autora acaba em sua análise reproduzindo as noções que critica porque, ao classificar as rebeliões das Minas no período colonial, Anastasia desconsidera algumas particularidades de cada revolta.

No final da década de 1990, o artigo As Câmaras Municipais no Império Português: $O$ Exemplo do Rio de Janeiro ${ }^{11}$ de Maria Fernanda Bicalho foi considerado pioneiro nos estudos das câmaras na América portuguesa. A autora abordou o papel exercido pelas municipalidades coloniais no Império Português. Ilustrando sua análise com a Câmara do Rio do Janeiro entre os séculos XVII e XVIII, Bicalho buscou entender as principais características das municipalidades no período colonial. As funções, ações nos tempos de crise, os pedidos aos representantes da Coroa foram alguns dos aspectos observados pela autora.

Mesmo tratando da Câmara do Rio de Janeiro, o texto aborda aspectos gerais das práticas sociais, econômicas e políticas presentes nas câmaras no período colonial. A autora comparou as diferenças entre as municipalidades em Portugal e no ultramar. $\mathrm{O}$ foco do texto está direcionado para as câmaras, evidenciando uma série de características que antes não eram encontradas pela historiografia. As tensões e negociações que existiam entre camarários, oficiais régios e rei são aprofundadas. Infelizmente, Bicalho restringe sua análise às

\footnotetext{
${ }^{10}$ ANASTASIA, Carla Maria Junho. Vassalos Rebeldes: violência coletiva nas Minas na primeira metade do século XVIII. Belo Horizonte: C/Arte, 1998.

${ }^{11}$ BICALHO, Maria Fernanda Bicalho. As Câmaras Municipais no Império Português : o exemplo do Rio de Janeiro. Revista Brasileira de História, São Paulo, v. 18, n.36, p. 251-280, 1998.
} 
municipalidades litorâneas, destacando apenas em uma das partes do texto a existência dessa instituição nos sertões ${ }^{12}$ :

\begin{abstract}
Não restritas à larga franja litorânea da colônia, as representações baseadas nos feitos e bravatas dos colonos na conquista e colonização do Brasil ultrapassaram em muito o limitado termo das aglomerações urbanas, extrapolando as sessões de vereança das Câmaras Municipais das cidades marítimas, abrangendo os longínquos sertões e sua população móvel e fluida. O bandeirantismo e a descoberta das minas desempenhou, nos sertões paulistas, a mesma função legitimadora para reivindicar ao Monarca privilégios e vantagens por parte da Câmara de São Paulo. Prova disto é a representação que enviara à Metrópole, em 07 de abril de 1700, solicitando não fossem doadas datas nas minas senão aos moradores daquela vila e anexas, por terem sido eles, "os descobridores e conquistadores das ditas minas, à custa de suas vidas e gasto de sua fazenda sem dispêndio da fazenda real."
\end{abstract}

A partir da década de 2000, os estudos sobre as municipalidades e o poder nas Minas aumentaram substancialmente. Muitos trabalhos estudaram o poder da Câmara de Vila Rica a partir de diferentes abordagens historiográficas, tais como: História Cultural ${ }^{13}$, História Econômica $^{14}$ e História Demográfica ${ }^{15}$. Além disso, reduziram a escala de análise concentrando-se em aspectos específicos da atividade camarária.

No livro Códigos e práticas: o processo de constituição urbana em Vila Rica colonial $(1702-1748)^{16}$, Maria Aparecida de Menezes Borrego busca entender o processo de urbanização através dos documentos da Câmara de Vila Rica, analisando o processo de formação da capitania. A autora enxerga o espaço como uma expressão da ideia de Portugal para a região mineradora. $\mathrm{O}$ espaço visava estabelecer à ordem e prevenir as sublevações.

Borrego evidencia as tensões entre os grupos, mas não procura destacar as relações entre os camarários e a Coroa. A autora examina como a questão urbana gerava um universo de tensão entre os colonos, oficiais régios, camarários e governadores. $\mathrm{O}$ trabalho foi imprescindível para esta dissertação, porque demonstra como a questão territorial na região mineradora era marcada pela política portuguesa para as Minas. Além disso, o estudo mostra como a urbanização do espaço causava tensão na sociedade mineradora.

\footnotetext{
${ }^{12}$ BICALHO, Maria Fernanda Bicalho. As Câmaras Municipais no Império Português : o exemplo do Rio de Janeiro. Revista Brasileira de História, São Paulo, v. 18, n.36, p. 251-280, 1998.

${ }^{13}$ SANTIAGO, Camila Fernanda Guimarães. Vila Ricas em festas: as festas promovidas pelo Senado da Câmara de Vila Rica (1711-1744). Belo Horizonte: UFMG, 2001.

${ }^{14}$ FIORAVANTE, Fernanda "Às custas do sangue, fazenda e escravos": formas de enriquecimento e padrão de ocupação dos ofícios da Câmara de Vila Rica, c. 1711 - c. 1736. Rio de Janeiro: UFRJ, PPGHIS, 2008.

${ }^{15}$ BORREGO, Maria Aparecida de Menezes. Códigos e práticas : o processo de constituição urbana em Vila Rica colonial (1702-1748). São Paulo: Annablume, 2004.

${ }^{16} \mathrm{Ibdem}$.
} 
A dissertação de Fernanda Fioravante ${ }^{17}$ detalha o perfil social e econômico dos homens bons que atuaram na câmara de Vila Rica entre 1711 e 1736. Utilizando o método de reconstituição de redes, Fioravante faz um trabalho minucioso de reconstrução do perfil econômico não só dos camarários, mas também da própria instituição municipal. Ao final da dissertação a autora concentra-se em três oficiais camarários, discutindo o perfil econômico e social dos homens bons de Vila Rica e a importância das redes de clientela na condução dos interesses das municipalidades da região mineradora.

Segundo a autora ${ }^{18}$, do ponto de vista econômico, participar do Senado da Câmara não era rentável porque os emolumentos e propinas auferidos durante a ocupação do cargo camarário eram inferiores aos rendimentos pessoais dos oficiais das municipalidades. Entretanto, as mercês e benesses que advinham da atividade camarária eram o diferencial ${ }^{19}$. Apesar do excelente trabalho com as fontes, a autora trata a Câmara de Vila Rica apenas como um meio de alavancar o status quo na sociedade mineradora. Ocorre uma minimização das tensões existentes na municipalidade Vilariquenha. A autora também desconsidera na sua análise a tradição insurgente que existia nas Minas e influenciava nas municipalidades. Isso acontece porque Fioravante supervaloriza em seu estudo as redes clientelares que compunham a municipalidade Vilariquenha.

Camila Fernanda Guimarães Santiago, na sua dissertação de mestrado intitulada Vila Ricas em festas ${ }^{20}$, investigou as cerimônias oficiais no Senado da Câmara de Vila Rica. A autora procurou retratar os principais aspectos das cerimônias oficiais, tais como: a organização, os rituais antes e durante os eventos, o pagamento das despesas e das propinas específicas as autoridades envolvidas nos eventos.

Santiago analisa no primeiro capítulo de seu trabalho os embates políticos causados não só pelo status que envolviam as festas e rituais, mas também, pelos abusos no recebimento das propinas e emolumentos pelos oficiais camarários para a realização dos

\footnotetext{
${ }^{17}$ FIORAVANTE, Fernanda "Às custas do sangue, fazenda e escravos": formas de enriquecimento e padrão de ocupação dos ofícios da Câmara de Vila Rica, c. 1711 - c. 1736. Rio de Janeiro: UFRJ, PPGHIS, 2008.

${ }^{18}$ Ibdem.

${ }^{19} \mathrm{Ibdem}$.

${ }^{20}$ SANTIAGO, Camila Fernanda Guimarães. Vila Ricas em festas: as festas promovidas pelo Senado da Câmara de Vila Rica (1711-1744). Belo Horizonte: UFMG, 2001.
} 
eventos. Segundo a autora, existiam freqüentes desvios nos emolumentos das festas e no recebimento das propinas $^{21}$.

Camila Santiago investigou também as negociações que a Câmara Vilariquenha tecia com Portugal para a realização de festas e cerimônias. Infere-se de sua análise que existem muitas intenções dentro das negociações que ultrapassavam o campo econômico e político ${ }^{22}$.

Os trabalhos de Maria Aparecida de Menezes Borrego, Fernanda Fioravante, Camila Fernanda Guimarães Santiago são importantes por fornecerem dimensões distintas da atividade camarária nas Minas. Borrego mostra como os camarários relacionavam-se com questões de urbanização. Já Santiago, demonstra como as festas e rituais influenciavam nas ações políticas da municipalidade de Vila Rica. Fioravante investiga como o perfil dos oficiais camarários de Vila Rica afetava na condução dos interesses na municipalidade.

Na década de 2000, os estudos sobre as relações de poder nas Minas também passaram por mudanças. Alguns trabalhos foram produzidos tendo como foco a análise das negociações políticas a partir dos motins. Esses estudos analisam profundamente os conflitos na região mineradora e são importantes porque oferecem uma nova perspectiva sobre as negociações políticas nas Minas.

Quanto aos trabalhos sobre a Sedição de Vila Rica de 1720, inúmeras pesquisas foram realizadas desde o início da década de 2000. Por exemplo, os trabalhos de Carlos Leonardo Kelmer Mathias $^{23}$ e João Henrique Ferreira de Castro $^{24}$ reconstituíram, através da metodologia de redes, a composição social da Revolta de Vila Rica.

Mathias buscou analisar, na primeira metade do século XVIII, as diferentes trajetórias de vida e estratégias de ação dos participantes da Sedição de Vila Rica de 1720. Para o autor, a cada novo governante, a elite local precisava estabelecer novas relações de clientela; ao

\footnotetext{
${ }^{21}$ SANTIAGO, Camila Fernanda Guimarães. Vila Ricas em festas: as festas promovidas pelo Senado da Câmara de Vila Rica (1711-1744). Belo Horizonte: UFMG, 2001.

${ }^{22}$ Ibdem.

${ }^{23}$ MATHIAS, Carlos Leonardo Kelmer. Jogos de interesses e redes clientelares na revolta mineira de Vila Rica (c. 1709 - c. 1736). Rio de Janeiro: UFRJ, PPGHIS, 2005.

${ }^{24}$ CASTRO, João Henrique Ferreira de. A repressão à Revolta de Vila Rica de 1720: Perdão e Punição sob a ótica da justiça no Império Ultramarino Português. Rio de Janeiro: UFRJ, PPGHIS, 2012.
} 
mesmo tempo os oficiais régios necessitavam do estabelecimento dessas relações para a manutenção de governabilidade nas Minas ${ }^{25}$.

Carlos Leonardo Kelmer Mathias realizou um trabalho minucioso com as fontes ao reconstituir a composição social do movimento de 1720. Entretanto, o autor investigou somente as formas de negociação no campo das relações pessoais. Pedidos de mercês e cargos são tratados como as principais situações de negociação dentro do conflito e os documentos referentes à revolta são colocados em segundo plano. Infere-se do estudo que a negociação em situação de conflito é um privilégio dos mais abastados do ultramar. Sobre as municipalidades, o trabalho do autor é enriquecedor porque as relações de clientela nas câmaras da região mineradora era um dos elementos que influenciava na condução de diversos interesses nas municipalidades ${ }^{26}$.

A dissertação de João Henrique Ferreira de Castro explorou o processo de punição e repressão a Sedição de Vila Rica. O objetivo foi mostrar que a violência empreendida na repressão e punição da revolta não representou a forma tradicional empregada na Minas até 1720. Para o autor, o Conde de Assumar inaugurou uma nova conduta do Império português com os rebelados de 1720. Castro demonstrou que essa forma de repressão e punição tornouse cada vez mais recorrente devido à ineficiência das negociações políticas e o lento processo de transformação na concepção de Razão de Estado do Império Português.

O trabalho de João Henrique Castro amplia as redes clientelares traçadas no estudo de Mathias, pesquisando arquivos de outras localidades como da Bahia. Porém, o autor afirma que a repressão e a punição da Sedição de Vila Rica de 1720 significaram uma mudança na forma de reprimir os conflitos na região mineradora sem analisar profundamente os anos posteriores a revolta. No trabalho, Castro coloca que a rebelião de Vila Rica de 1720 inaugurou múltiplas formas de negociação do perdão. No estudo, não há uma continuação que permita identificar se a negociação de perdões foi uma prática recorrente em outros conflitos

\footnotetext{
${ }^{25}$ MATHIAS, Carlos Leonardo Kelmer. Jogos de interesses e redes clientelares na revolta mineira de Vila Rica (c. 1709 - c. 1736). Rio de Janeiro: UFRJ, PPGHIS, 2005.

${ }^{26}$ Ibdem.
} 
ao longo do século XVIII. Castro também desconsidera a possibilidade do perdão ter coexistido com as punições ${ }^{27}$.

A ocupação da região mineradora e o Levante dos Emboabas é outra parte da história das Minas imprescindível para esse trabalho, porque só através desse estudo podemos entender o contexto social em que se constituiu a Câmara de Vila Rica.

Neste particular, o livro Paulistas e emboabas no coração das Minas ${ }^{28}$, de Adriana Romeiro, trouxe uma visão inovadora sobre o Levante dos Emboabas fazendo uma análise sobre o imaginário político e as relações de poder na formação das Minas. Adriana mostra a negociação política como uma das ferramentas necessárias na disputa de poder e privilégios nas Minas entre emboabas e paulistas. Além disso, distingue as formas de negociação adotadas pelos grupos para negociar com o Rei.

O trabalho de Adriana Romeiro serve como base para o estudo do Levante dos Emboabas nesta dissertação, porque a autora demonstra que as formas de negociação política adotadas pelos paulistas foram incorporadas pela população das Minas ao longo do século XVIII. Além disso, a autora considera que existiam múltiplas formas de negociar com a Coroa $^{29}$.

Para Romeiro, no início da mineração, os paulistas negociavam com o Estado luso as remunerações que receberiam antes de cumprir as diligências, pois, no passado, a monarquia portuguesa tinha prometido aos sertanistas recompensas por suas ações no sertão nordestino e não havia cumprido. A autora, através dos paulistas, mostra que existiram formas de negociação nas América portuguesa que não se encaixavam nos padrões do Antigo Regime ${ }^{30}$.

A historiografia sobre a administração das Minas Setecentistas também é essencial para entender a formação da Câmara de Vila Rica porque a instituição foi instalada nas Minas com o intuito da Coroa fazer-se presente na região.

\footnotetext{
${ }^{27}$ CASTRO, João Henrique Ferreira de. A repressão à Revolta de Vila Rica de 1720: Perdão e Punição sob a ótica da justiça no Império Ultramarino Português. Rio de Janeiro: UFRJ, PPGHIS, 2012.

${ }^{28}$ ROMEIRO, Adriana. Paulistas e emboabas no coração das Minas: idéias, práticas e imaginário político no século XVIII. Belo Horizonte: Editora da UFMG, 2008.

${ }^{29}$ MATHIAS, Carlos Leonardo Kelmer. Jogos de interesses e redes clientelares na revolta mineira de Vila Rica (c. 1709 - c. 1736). Rio de Janeiro: UFRJ, PPGHIS, 2005.

${ }^{30} \mathrm{Ibdem}$.
} 
A tese Governo de mineiros: "de como meter as Minas numa moenda e beber-lhe o caldo dourado" 1693 a $1737^{31}$, de Maria Verônica Campos, investigou detalhadamente o processo de instalação das estruturas político-administrativa do Estado Português nas Minas no início do século XVIII. A autora examinou os mecanismos utilizados por Portugal para impor na região mineradora uma organização política e administrativa que permitisse maior controle fiscal e político da região mineradora pelo Estado luso. Campos analisou os governos das Minas, entre 1694 e 1736, destacando a divisão administrativa, as funções dos cargos da administração portuguesa na região, a implantação da fiscalidade, a importância dos burocratas e dos oficiais régios, os motins e outras formas de rebelar-se contra $\mathrm{Coroa}^{32}$.

A autora prendeu sua análise a uma linha interpretativa sobre o ultramar de forma engessada e enfatizou o caráter fiscal das medidas do governo. Apesar disso, o trabalho é imprescindível para os pesquisadores que investigam o poder da Coroa portuguesa nas Minas no início do século XVIII. ${ }^{33}$.

Fontes e metodologia

Recorrendo aos métodos avaliativos e analíticos da história, o trabalho busca estabelecer uma conexão entre a produção historiográfica elencada na revisão bibliográfica e a documentação. As fontes utilizadas são provisões, cartas, requerimentos, dentre outras.

As provisões eram concessões régias que tratavam do provimento dos cargos administrativos ou das doações de sesmaria. Esses documentos ajudam a pesquisa porque mostram os indivíduos que compunham os cargos nas Minas no período estudado. As cartas e requerimentos da Câmara são imprescindíveis para a pesquisa porque é possível analisar a atuação política dos camarários de Vila Rica no Império português e como se deu a instalação do aparelho político-administrativo nas Minas.

A relação das receitas e despesas da municipalidade Vilariquenha permite estudar a atuação dos oficiais da Câmara de Vila Rica na execução de suas responsabilidades locais.

\footnotetext{
${ }^{31}$ CAMPOS, Maria Verônica. Governo de mineiros: "de como meter as Minas numa moenda e beber-lhe o caldo dourado" 1693 a 1737. São Paulo: USP, FFLCH, 2002.

${ }^{32}$ Ibdem.

${ }^{33}$ NOVAIS, Fernando A. Portugal e Brasil na crise do antigo sistema colonial: (1777-1808). 8. ed. São Paulo: Hucitec 2005.
} 
Essas fontes abordam questões como os gastos com festas e cerimônias religiosas, as ações para o controle do abastecimento alimentar e a manutenção do regimento dos dragões. Já os Termos da Câmara de Vila Rica os acordos firmados entre camarários, Coroa e governadores.

Outros documentos como Códice Costa Matoso ${ }^{34}$ e o Discurso histórico e político sobre a sublevação que nas minas houve no ano de $1720^{35}$ também são de suma importância, pois revelam diferentes faces das negociações na Câmara de Vila Rica.

O Códice, apesar de estar fora do recorte temporal proposto pela pesquisa, possui referências das negociações tecidas pelas câmaras da região mineradora durante toda a primeira metade do século XVIII ${ }^{36}$. Já o Discurso, além demonstrar os problemas envolvendo o estabelecimento do poder da Coroa, evidencia a visão dos funcionários régios dos povos das $\operatorname{Minas}^{37}$.

Estrutura da dissertação

Na primeira parte desta dissertação, Formação das Minas e Levante dos Emboabas, destaco o debate historiográfico sobre a ocupação da zona mineradora e as conseqüências para os primeiros habitantes da região. Também abordo como o fim do Levante dos Emboabas possibilitou o início do processo de instalação do aparelho político e administrativo português nas Minas. No segundo capítulo, A Câmara de Vila Rica e a Sedição de 1720, busco evidenciar como foram os primeiros anos da municipalidade Vilariquenha e o impacto gerado na região mineradora pelos revoltosos de 1720. Na última parte, Entre conflitos e mediações atividade camarária nas Minas, tento mostrar como se deu o processo de instalação das municipalidades na região mineradora na década de 1710 e como a sociedade do Antigo Regime limitou o alargamento do poder das câmaras nas Minas.

\footnotetext{
${ }^{34}$ CÓDICE Costa Matoso. Belo Horizonte: Fundação João Pinheiro, vol. 1 e 2, 1999. Coordenação-geral de Luciano Raposo de Almeida Figueiredo e Maria Verônica Campos.

${ }^{35}$ DISCURSO histórico e político sobre a sublevação que nas Minas houve no ano de 1720. Belo Horizonte: Fundação João Pinheiro, 1994. Estudo crítico de Laura de Mello e Souza.

${ }^{36}$ CÓDICE, op. cit.

${ }^{37}$ DISCURSO, op. cit.
} 
CAPítULO 1

FORMAÇÃO DAS MINAS E O LEVANTE DOS EMBOABAS 
O objetivo deste capítulo é apresentar uma discussão historiográfica sobre os eventos da primeira década de colonização do interior da América portuguesa. É necessário discutirmos o começo da mineração porque a formação das Minas influenciou no processo de instauração da organização política e administrativa do Estado Português na zona mineradora. O Levante dos Emboabas também é importante porque apenas depois do fim do conflito a Coroa conseguiu iniciar o processo efetivo de instalação das estruturas político-administrativa do Estado Português nas Minas.

$\mathrm{Na}$ primeira parte do capítulo, Os primeiros achados e a ocupação da região mineradora, demonstro o impacto da exploração do ouro no Império português, dando maior atenção a ocupação desordenada do interior da América lusa, aos problemas enfrentados pelos primeiros mineradores e às medidas tomadas pela Coroa em relação ao achamento de metais. $\mathrm{Na}$ segunda parte, As tensões entre paulistas e forasteiros, apresento a construção da identidade paulista ao longo dos dois primeiros séculos de colonização portuguesa e como ocorreram as primeiras desavenças entre sertanistas e forasteiros na região mineradora. $\mathrm{Na}$ última parte do capítulo, $O$ Levante dos Emboabas, discorro sobre o conflito e suas conseqüências para as Minas.

1.1. Os primeiros achados e a ocupação da região mineradora

O achamento das minas no final dos seiscentos representou mudanças tanto no cotidiano colonial, quanto no metropolitano. Segundo João Furtado Pinto ${ }^{38}$, a descoberta de uma atividade econômica, que possibilitava rápido enriquecimento, serviu de estímulo para a grande imigração do Reino para a região central da América lusa. Dentro da colônia não foi diferente. $\mathrm{O}$ fluxo migratório para área de exploração de metais preciosos recém-descoberta também foi grande.

\footnotetext{
${ }^{38}$ FURTADO, João Pinto. "Viva o Rei, viva o povo, e morra o governador": tensão política e práticas de governo nas Minas Setecentistas. In BICALHO, Maria Fernanda Baptista; FERLINI, Vera Lúcia Amaral (Coord.). Modos de governar: idéias e práticas políticas no Império português, séculos XVI-XIX. São Paulo: Alameda, 2005.
} 
O afluxo de pessoas para o sertão da América portuguesa foi registrado pelo jesuíta Antonil, que destacou a heterogeneidade social presente na nova área de exploração aurífera e a dificuldade de mineirar em uma região até então inóspita ${ }^{39}$ :

\begin{abstract}
A sede insaciável do ouro estimulou a tantos a deixarem suas terras e a meterem-se por caminhos tão ásperos como são os das minas, que dificultosamente se poderá dar contado número de pessoas que atualmente lá estão. Contudo, os que assistiram nelas nesses últimos anos por largo tempo, e as correram todas, dizem que mais de trinta mil almas se ocupam, umas em catar, e outras em mandar catar nos ribeiros do ouro, e outras em negociar, vendendo e comprando o que se há mister não só para a vida, mas para o regalo, mais que nos portos do mar. Cada ano vem nas frotas quantidade de portugueses e de estrangeiros para passarem às Minas. Das cidades, vilas, recôncavos, e sertões do Brasil vão brancos, pardos e pretos e muitos índios de que os paulistas se servem. A mistura é de toda a condição de pessoas: [...] muitos dos quais não têm no Brasil convento nem casa.
\end{abstract}

Os primeiros mineradores passaram por uma série de dificuldades. A falta de uma organização política e administrativa somada ao afluxo populacional ocasionou a escassez de gêneros de primeira necessidade. As crises de fome de 1697-1698 e 1700-1701 são um retrato desta realidade. Segundo Virgílio Pinto Noya ${ }^{40}$, os novos mineradores, muitas vezes, abandonavam as minas porque, mesmo com os bolsos cheios de ouro, não conseguiam comprar bens de primeira necessidade. A oferta de alimentos era desproporcional ante a enorme quantidade de pessoas que habitavam a região.

Os problemas de abastecimento prejudicaram também a prospecção de ouro nas minas porque a falta de mantimentos gerava a dispersão populacional ${ }^{41}$. Em carta de novembro de 1700, Arthur de Sá e Meneses relata a situação da área mineradora ao vice-rei D. João de Lencastro $^{42}$ :

[...] porém falo sobre a falta de mantimentos, porque está custando um alqueire de milho a quinze e dezesseis oitavas de ouro, e o de feijão a trinta, e a carne de vaca a quatro e a seis arretéis por oitava, e os mais gêneros a este respeito, causa porque se retirarão muitos Mineiros para a montaria para haverem de sustentar a sua gente, e outros para suas casas, deixando plantados para voltarem em março, e entendendo que haverá muitas lavras para o ano pelos muitos mantimentos que se esperam, e juntamente pelo gado que se tem mandado buscar aos currais da Bahia e Pernambuco, o que se serve de grande adjutório para se poderem lavrar as Minas [...].

\footnotetext{
${ }^{39}$ ANTONIL, Andre João. Cultura e Opulência do Brasil por suas Drogas e Minas. São Paulo: Companhia Editora Nacional, 1967, p. 167.

${ }^{40}$ PINTO, Virgilio Noya. O ouro brasileiro e o comércio anglo-português: uma contribuição aos estudos da economia atlântica no século XVIII. São Paulo: Companhia Editora Nacional, 1979, p. 53.

${ }^{41}$ ROMEIRO, Adriana. Paulistas e emboabas no coração das Minas: idéias, práticas e imaginário político no século XVIII. Belo Horizonte, MG: Editora UFMG, 2008.

${ }^{42}$ Arquivo da Casa de Cadaval, códice 1087, fl. 481-481v, CÓPIA da carta que Arthur de Sá e Meneses, governador do Rio de Janeiro, escrevo ao D. João Lencastro, governador e capitão-geral deste Estado do Brasil. Rio das Velhas, 30/11/1700. In Idem, nota 39, p. 548-549.
} 
Ao sair das minas em busca de alimentos, os mineradores deixavam as lavras a mercê de invasores, além de não contribuírem para o aumento da produção aurífera. Para buscar resolver o problema, a Coroa tentou interligar a região mineradora às outras áreas de povoamento da América portuguesa, através da abertura de novos caminhos. A precária articulação geográfica implantada na colônia produziu novos estímulos para produção e o comércio $^{43}$.

Segundo João Antônio de Paula ${ }^{44}$, a economia das Minas se tornou mais dinâmica e diversificada. Porém, o desenvolvimento econômico da região mineradora, atrelada às outras áreas de colonização da América lusa, não significou uma mudança na qualidade das relações econômicas, ou a emergência de uma nova dinâmica econômica na colônia portuguesa.

Em 1711, após o Levante dos Emboabas, D. Antônio de Albuquerque iniciou o processo de instalação do poder político e administrativo da Coroa na região mineradora, tomando uma série de medidas, como a criação das primeiras vilas ${ }^{45}$. Após essa mudança, a função de garantir o abastecimento e regular os preços dos mantimentos ficou a cargo das câmaras e dos ouvidores $^{46}$. As municipalidades se empenharam em melhorar a disponibilidade de alimentos nas Minas. Por exemplo, nos primeiros anos da Câmara de Vila Rica, um dos assuntos mais tratados era como garantir o abastecimento do milho, feijão e cortes de gado ${ }^{47}$. Entretanto, o problema com a falta de mantimentos continuou a assombrar as Minas.

Durante o século XVIII, a dificuldade com o abastecimento alimentar sempre ocasionou grande alvoroço entre a população da região mineradora. Uma das causas do problema foi à ação dos atravessadores que revendiam os gêneros de primeira necessidade de forma ilegal.

\footnotetext{
${ }^{43}$ PAULA, João Antônio de Paula. A mineração de Ouro em Minas Gerais no século XVIII. In RESENDE, Maria Efigênia Lage de; VILlALTA, Luiz Carlos (Coord.). História das Minas Gerais. As minas setecentistas. Vol. 1. Belo Horizonte, MG: Autêntica, Companhia do Tempo, 2007, p. 286-287.

${ }^{44} \mathrm{Ibdem}$, p. $286-287$.

${ }^{45}$ GOUVÊA, Maria de Fátima da Silva. Dos poderes de Vila Rica do Ouro Preto: notas preliminares sobre a organização político-administrativa na primeira metade do século XVIII. Revista Varia História, Belo Horizonte, $\mathrm{n}^{\mathrm{O}} 31$, p. 120-140, Jan/Jun 2004.

${ }^{46}$ ANASTASIA, Carla Maria Junho. Vassalos Rebeldes: violência coletiva nas Minas na primeira metade do século XVIII. Belo Horizonte: C/Arte, 1998.

${ }^{47}$ ATAS da câmara de Vila Rica. Revista do Arquivo Público Mineiro. Ano XXV, 1937, 1-165.
} 
Para obter maior ganho nas vendas, muitos atravessadores estocavam os bens até alcançarem um preço mais vantajoso ou vendiam os produtos destinados para o mercado das minas, em outras paragens, causando escassez de mantimentos e descontentamento na população. A atividade era comum e as Câmaras tentaram de diversas maneiras coibirem a fuga de mantimentos, através do controle e dos termos de obrigação firmados com os produtores da região. O edital da Câmara de Vila Rica de 1723 discorre sobre essa situação ${ }^{48}$ :

[...] a nossa notícia veio que muitas pessoas, moradores na travessa do Teixeira e neste Ouro Preto, e mais partes desta vila, tem atravessado e costuma atravessar os mantimentos que vem para esta vila, e seu termo, dos portos do mar, como são peixe, azeite, vinagre, queijos, farinha do Reino, e mais molhados, o que é grande prejuízo do Povo, por estes tais atravessadores (pretendem) os revender, e principalmente retendo-os em casa, a esperar os maiores preços $[\ldots]$.

Muitas vezes, a insatisfação da população era provocada por ações da própria câmara ou de outros oficiais régios presentes nas Minas. O aumento de preços dos mantimentos também gerava o descontentamento da população e motivou uma série de motins no século XVIII na área mineradora ${ }^{49}$. Por exemplo, em 1721, na Vila de São João Del Rei, os moradores amotinaram-se contra o estabelecimento do contrato de aguardente instaurado pela Câmara $^{50}$. No mesmo ano, a Câmara de Vila Real e o ouvidor de Rio das Velhas, resolveram estabelecer um contrato para o corte de carnes, tirando a liberdade de comercialização do produto. $\mathrm{O}$ povo rebelou-se contra essa medida e o contrato foi suspenso ${ }^{51}$.

Apesar dos constantes problemas com o abastecimento de gêneros enfrentados pela população das minas durante os Setecentos, as severas crises de fome do início da mineração não voltaram a assolar a região ${ }^{52}$.

A carência de organização política e administrativa nas minas no início do século XVIII contribuiu também para o aumento da violência e o acirramento dos conflitos entre os grupos em disputa pelo poder da região, como argumentou Antoni1 ${ }^{53}$ :

\footnotetext{
${ }^{48}$ Arquivo Público Mineiro. Seção Colonial, CMOP 06, fls. 41-41v, EDITAL da Câmara de Vila Rica de janeiro de 1723. Apud ANASTASIA, Carla Maria Junho. Vassalos Rebeldes: violência coletiva nas Minas na primeira metade do século XVIII. Belo Horizonte: C/Arte, 1998, p. 37.

${ }^{49}$ ANASTASIA, Carla Maria Junho. Vassalos Rebeldes: violência coletiva nas Minas na primeira metade do século XVIII. Belo Horizonte: C/Arte, 1998.

${ }^{50}$ Ibdem.

${ }^{51}$ Ibdem

${ }^{52}$ Ibdem.
} 
[...] não houve até o presente coação ou governo algum bem ordenado, e apenas se guardam algumas leis que pertencem as datas e repartições dos ribeiros. No mais, não há, ministros nem justiças que tratem ou possam tratar do castigo dos crimes, que não são poucos, principalmente dos homicídios e furtos. Quanto ao espiritual, havendo até agora dúvidas entre os prelados acerca da jurisdição, os mandados de uma e outra parte, ou como curas, ou como visitadores, se acharam bastantemente embaraçados, não pouco embaraçaram a outros, que não acabam de saber a que pastor pertencem aqueles novos rebanhos. E, quando se averigúe o direito de provimento dos párocos, pouco hão de ser temidos e respeitados naquelas freguesias móveis de um lugar para outro, como os filhos de Israel.

A fraca presença do Estado português no início da exploração das minas deveu-se, em parte, às dúvidas que a Coroa tinha em relação à proporção dos achados auríferos e aos problemas econômicos e sociais que, porventura, a exploração dos metais preciosos poderia causar $^{54}$.

Do ponto de vista econômico, a exploração das minas constituía um empreendimento ousado para Coroa. De acordo com Adriana Romeiro ${ }^{55}$, o deslocamento de recursos de áreas vitais para economia do Império português, como a produção do açúcar e do tabaco, para uma atividade nova e arriscada causava receio no Conselho Ultramarino e no Rei. Também, o despejo de uma vultosa quantia de ouro no mercado poderia ocasionar uma baixa no preço do metal, causando grande prejuízo para $\mathrm{Coroa}^{56}$.

Os escritos políticos e teológicos portugueses da época moderna colaboraram também para o desconforto da Coroa em investir na produção aurífera. Existia uma concepção de que as áreas de extração de metais preciosos possuíam especificidades que levavam seus habitantes a terem ações políticas e morais deturpadas, gerando um clima de instabilidade social $^{57}$.

Segundo Francisco Eduardo de Andrade ${ }^{58}$, na concepção coeva, o ouro em si não era considerado ruim. Ao contrário, o metal era tido como um elemento da natureza, fruto da criação divina, e, portanto, não produzia o mal. Entretanto, acreditava-se que o uso do ouro era amoral porque, devido à beleza do metal, os homens não conseguiam discernir entre o

\footnotetext{
${ }^{53}$ ANTONIL, Andre João. Cultura e Opulência do Brasil por suas Drogas e Minas. São Paulo: Companhia Editora Nacional, 1967, p. 167-168.

${ }^{54}$ ROMEIRO, Adriana. Paulistas e emboabas no coração das Minas: idéias, práticas e imaginário político no século XVIII. Belo Horizonte, MG: Editora UFMG, 2008.

${ }^{55}$ Ibdem.

${ }^{56}$ Ibdem.

${ }^{57}$ ANDRADE, Francisco Eduardo de. A invenção das Minas Gerais: empresas, descobrimentos e entradas nos sertões do ouro da América portuguesas. $1^{a}$ ed. Belo Horizonte, MG: Autêntica Editora/ Editora PUC Minas, 2008.

${ }^{58}$ Ibdem.
} 
bem e o mal e caiam em pecado. Condenavam-se os vícios e os pecados desencadeados pela cobiça do homem, motivada pelo ouro. Tal imaginário negativo era corrente e consta em muitos escritos da época que retratam as minas ${ }^{59}$.

A falta de um projeto colonizador para as minas também foi um empecilho, inicialmente, para a exploração dos metais preciosos na região central da América Portuguesa ${ }^{60}$.

$\mathrm{O}$ advento das minas encetou uma disputa entre as autoridades régias no Brasil a respeito da forma como deveria ser colonizada a região mineradora. Arthur de Sá e Meneses, então governador da Repartição Sul, entrou em rota de colisão com o governador geral do Brasil, D. João de Lencastro, ao Reivindicar a jurisdição da região mineradora. Lencastro defendia que a nova área de exploração de metais preciosos deveria ficar sob jurisdição da Bahia, com a alegação de que as minas eram mais próximas da região baiana do que do Rio de Janeiro e de São Paulo. Além disso, o governador-geral garantiria o abastecimento da região aurífera e a comunicação com a zona costeira pela Bahia e pelo Rio Doce ${ }^{61}$.

O projeto do governador geral foi rejeitado pelo Conselho Ultramarino, que via na abertura de vários caminhos para a área mineradora, rotas para o descaminho de metais $\mathrm{e}$ eventuais invasões estrangeiras. Em 1702, a Coroa proibiu qualquer comunicação entre a Bahia e as minas. Já em 1705, a monarquia portuguesa determinou o fim da construção do caminho para a região mineradora via o rio Doce. Simultaneamente, pelas mãos de Arthur de Sá e Meneses, a Coroa iniciou o processo de colonização da região mineradora, rearranjando as jurisdições das capitanias da Repartição Sul e instalando algumas instituições do Estado Português nas Minas, como as câmaras.

A mudança na jurisdição das capitanias foi realizada em 1698, mas, os impactos administrativos na região aurífera só foram sentidos no começo do século XVIII com o início

\footnotetext{
${ }^{59}$ ANDRADE, Francisco Eduardo de. A invenção das Minas Gerais: empresas, descobrimentos e entradas nos sertões do ouro da América portuguesas. $1^{\text {a }}$ ed. Belo Horizonte, MG: Autêntica Editora/ Editora PUC Minas, 2008, p.121.

${ }^{60}$ ROMEIRO, Adriana. Paulistas e emboabas no coração das Minas: idéias, práticas e imaginário político no século XVIII. Belo Horizonte, MG: Editora UFMG, 2008.

${ }^{61}$ Ibdem.
} 
do processo de instalação das estruturas do Estado Português na área mineradora. ${ }^{62}$ Essas medidas enterraram de vez a pretensão de D. João de Lencastro de ter jurisdição sobre as minas através da Bahia ${ }^{63}$.

Quando assumiu o governo da capitania do Rio de Janeiro, São Paulo e Minas do Ouro, Arthur de Sá e Meneses adotou a política de portas abertas para as minas visando maior exploração das jazidas e a descoberta de novos veios auríferos ${ }^{64}$. No regimento de 1702 , ficou estabelecido o privilégio do couto, que consistia na ampla abertura das minas para a imigração. Apenas as pessoas acusadas de crime de lesa-majestade estavam impedidas de desfrutar da exploração do ouro da região mineradora. Posteriormente, a política de portas abertas revelou ser um transtorno para a monarquia portuguesa, porque a inexistência de uma organização político-administrativa, capaz de lidar com as necessidades de uma grande população recém-chegada, transformaram a parte central da colônia em um barril de pólvora.

Para contornar a instabilidade política, em 1705, a Coroa começou a restringir à presença de grupos considerados nocivos à boa ordem nas minas ${ }^{65}$. Vadios, oficiais mecânicos e religiosos foram taxados como perturbadores da paz e descaminhadores de metais preciosos, conforme argumenta Fioravante ${ }^{66}$.

Durante o século XVIII, a monarquia portuguesa tomou outras medidas para garantir a boa ordem na região mineradora. Em 1709, 1711 e 1720, o Rei restringiu a saída de pessoas do Reino (principalmente da província do Minho) para as minas, com o objetivo de diminuir o afluxo de pessoas para a área mineradora e evitar a sangria populacional em Portugal $^{67}$. Entretanto, o problema perdurou por todo o século XVIII. Em ordem de 1725, D. João V

\footnotetext{
${ }^{62}$ GOUVÊA, Maria de Fátima da Silva. Dos poderes de Vila Rica do Ouro Preto: notas preliminares sobre a organização político-administrativa na primeira metade do século XVIII. Revista Varia História, Belo Horizonte, $\mathrm{n}^{\circ}$ 31, p. 120-140, Jan/Jun 2004, p. 123.

${ }^{63}$ ROMEIRO, Adriana. Paulistas e emboabas no coração das Minas: idéias, práticas e imaginário político no século XVIII. Belo Horizonte, MG: Editora UFMG, 2008.

${ }^{64}$ FIORAVANTE, Fernanda "Às custas do sangue, fazenda e escravos": formas de enriquecimento e padrão de ocupação dos ofícios da Câmara de Vila Rica, c. 1711 - c. 1736. Rio de Janeiro: UFRJ, PPGHIS, 2008.

${ }^{65}$ Ibdem.

${ }^{66}$ Ibdem.

${ }^{67}$ Ibdem.
} 
determinou que o governador das Minas, D. Lourenço de Almeida, remetesse os frades capuchos para seus conventos ${ }^{68}$ :

[...] me pareceu ordena-vos façais observar inviolavelmente as minhas reais ordens que há neste particular não consentindo aí os tais religiosos capuchos, nem os das mais religiões e os façais voltar logo, caso que aí chegarem para os seus conventos, pois certamente os não leva a essas terras o espírito de missionarem, senão o de granjearem muitos interesses, vivendo sem religião e com muito distraimento e maus costumes, de que muitos são notados e vos hei por mui recomendada a infalível execução desta minha real disposição [...].

Não obstante as dúvidas e os problemas sociais e políticos retratados nessa parte do capítulo, a Coroa iniciou o processo de instalação do aparato político-administrativo português nas minas ${ }^{69}$. A partir de 1704 , ocorreu a descoberta das primeiras jazidas de ouro mais profundas ${ }^{70}$, dando a Coroa maior segurança sobre o potencial aurífero da região e um incentivo para fazer-se cada vez mais presente nas minas. Entretanto, o processo de instalação das estruturas do Estado português na área mineradora não foi fácil. Os pólos de poder privado, que disputavam o controle da região, dificultaram o domínio da $\mathrm{Coroa}^{71}$.

\subsection{As tensões entre paulistas e forasteiros}

O descobrimento das minas no sertão da América portuguesa no final do século XVII não foi uma coincidência. A Coroa lusa sempre incentivou a procura por metais preciosos na colônia $^{72}$. No processo de busca e achamento dos metais, os paulistas tiveram papel fundamental. Nada mais justo que os moradores de Vila de São Paulo desfrutassem dos louros da conquista. Porém, como foi dito anteriormente, o ouro atraiu um grande contingente populacional para as minas e os recém-chegados também queriam participar da exploração. $\mathrm{O}$

\footnotetext{
${ }^{68}$ SOBRE não consentir frades nestas Minas. Carta de D. João V a D. Lourenço de Almeida, 02/05/1725. In TRANSCRIÇÃO da primeira parte do Códice 23 - Seção Colonial. Registro de Alvarás, cartas e ordens régias e cartas do Governador ao Rei, 1721-1731. Revista do Arquivo Público Mineiro. Ano XXX, 1979, p. 117-278, p.221.

${ }^{69}$ PAULA, João Antônio de Paula. A mineração de Ouro em Minas Gerais no século XVIII. In RESENDE, Maria Efigênia Lage de; VILlaltA, Luiz Carlos (Coord.). História das Minas Gerais. As minas setecentistas. Vol. 1. Belo Horizonte, MG: Autêntica, Companhia do Tempo, 2007.

${ }^{70}$ Nas Minas setecentistas, a prospecção do ouro de aluvião predominou, mas, a profundidade onde se encontrava o metal variou de acordo com as técnicas utilizadas. No final do século XVII, os mineradores empregavam técnicas rudimentares e concentravam-se em explorar o ouro no leito dos rios porque era de fácil prospecção. Todavia, esses veios eram superficiais e esgotavam-se rapidamente. Com a introdução de novas técnicas no início do século XVIII, o ouro das margens dos rios (profundidade média) e das encostas (alta profundidade) passou a ser explorado, conferindo maior credibilidade a mineração na região central da América portuguesa. PINTO, Virgilio Noya. O ouro brasileiro e o comércio anglo-português: uma contribuição aos estudos da economia atlântica no século XVIII. São Paulo: Companhia Editora Nacional, 1979.

${ }^{71}$ ROMEIRO, Adriana. Paulistas e emboabas no coração das Minas: idéias, práticas e imaginário político no século XVIII. Belo Horizonte, MG: Editora UFMG, 2008.

${ }^{72}$ PAULA, op. cit.
} 
choque de interesses entre paulistas e forasteiros logo se transformou em um conflito pelo poder na região mineradora no início dos Setecentos ${ }^{73}$.

Desde o começo da colonização das minas, os primeiros povoadores paulistas e os recém-chegados de outras paragens do Império português encetaram uma disputa pelo poder na região. As divergências já começavam nos costumes e tradições dos grupos ${ }^{74}$. Os paulistas, após dois séculos protagonizando a conquista dos gentios nos sertões da América Portuguesa, tinham adquirido hábitos estranhos aos forasteiros, conforme observou D. Pedro Miguel de Almeida, o Conde de Assumar, em sua rápida estada em São Paulo ${ }^{75}$ :

[...] eles (paulistas) vinham tão ridículos cada um por seu modo, que era gosto ver a diversidade das modas, e das cores tão esquisitas porque havia casacas verdes com botões encarnados, outras azuis agaloadas por uma forma nunca vista e finalmente todas extravagantes, vinham alguns com as cabeleiras tão acima dos olhos, que se podia duvidar se tinham frente, traziam então o chapéu caído para trás, que faziam umas formosas figuras principalmente aqueles que abotoavam as casacas muito acima.

A ascendência indígena dos paulistas era tratada nos escritos coetâneos de forma pejorativa. Descritos como vassalos indômitos, rebeldes e autônomos pelos escritos antipaulistas, os sertanistas se tornaram figuras depreciadas no imaginário social e político do Império Português. Os contemporâneos associavam os homens de Vila de São Paulo ao mito do homem selvagem, destacando uma aparente aversão às normas da vida política, à boa ordem e à civilização. A assimilação dos costumes indígenas pelos paulistas era igualmente desprezada pelos europeus e contribuía para a desvalorização da população de Serra Acima ${ }^{76}$.

A origem indígena do povo de Vila de São Paulo advinha dos inúmeros enlaces, muitas vezes forçados, entre as mulheres do gentio e os sertanistas. Durante as expedições de apresamento, os bandeirantes tinham predileção pelo gentio mais jovem porque, na concepção coeva, eram mais fáceis de serem domesticados, no caso dos homens, e, no caso feminino,

\footnotetext{
${ }^{73}$ ROMEIRO, Adriana. Paulistas e emboabas no coração das Minas: idéias, práticas e imaginário político no século XVIII. Belo Horizonte, MG: Editora UFMG, 2008.

${ }^{74}$ RUSSEL-WOOD, A. J. R. Identidade, etnia e autoridade nas Minas Gerais do século XVIII: leituras do Códice Costa Matoso. in: Varia História, Belo Horizonte, n. 21, julho de 1999, p. 100-118.

${ }^{75}$ DIÁRIO da jornada que fez o Exmo. Senhor D. Pedro desde o Rio de Janeiro até a cidade de São Paulo, e desta até as Minas. Ano de 1717. Revista do Serviço do Patrimônio Histórico e Artístico Nacional, Rio de Janeiro, v. 3, 1939, p. 302.

${ }^{76}$ ROMEIRO, op. cit.
} 
eram mais desejáveis como parceiras sexuais. Para os paulistas, era comum tomarem as mulheres capturadas nas expedições como suas esposas e concubinas ${ }^{77}$.

A coexistência de elementos indígenas e europeus na cultura paulista era considerada anormal pelos contemporâneos. O catolicismo, a presença da língua portuguesa, os feitos heróicos e a organização administrativa e política da Vila de São Paulo eram tidos como características tipicamente européias. Entretanto, a resistência às autoridades régias e religiosas era um dos elementos que afastavam os paulistas do padrão europeu desejado. Conforme observou Russel-Wood, quanto mais distante culturalmente da metrópole maior o grau de marginalização do indivíduo na sociedade do Antigo Regime ${ }^{78}$ :

[...] Vistas do centro, isto é, de Portugal, que era (segundo os metropolitanos) a epítome da ortodoxia religiosa, da civilidade, da moralidade e da estabilidade, a terra e as pessoas do Brasil eram marginalizadas, na medida em que se desviavam desses ideais. Isto se aplicava não só aos indivíduos, seus valores e modo de vida, mas se estendia ao clima e ao território. A infinita extensão do sertão despertava medo nos europeus, acostumados a espaços controlados. No nível humano, pessoas portuguesas de nascimento eram vistas mais próximas do ideal. Pessoas nascidas no Brasil mas com ascendência portuguesa por ambos os lados era algo que se afastava do modelo. A marginalização se acelerava à medida que incluía pessoas de paternidade racial mista, de naturalidade ou ascendência ameríndia ou africana.

O apresamento dos gentios gerou também muitas desavenças entre religiosos e paulistas na América Portuguesa ${ }^{79}$. Os jesuítas eram contra a escravização indígena e acreditavam que os paulistas aproveitavam da prerrogativa da guerra justa para justificar a captura indiscriminada do gentio. A disputa pelo domínio da população indígena corroborou para a presença negativa dos paulistas nos escritos jesuíticos ${ }^{80}$. Os religiosos foram os principais autores dos textos antipaulistas. Todavia, os sertanistas também procuraram dar sua versão da história.

A relação entre sertanistas e indígenas se constituiu de forma ambígua. Ao mesmo tempo em que entravam nos sertões para capturar os gentios e escravizá-los, utilizavam a língua e os costumes indígenas no cotidiano. Na carta enviada ao Rei por Domingos Jorge

\footnotetext{
${ }^{77}$ RUSSEL-WOOD, A. J. R. Identidade, etnia e autoridade nas Minas Gerais do século XVIII: leituras do Códice Costa Matoso. in: Varia História, Belo Horizonte, n. 21, julho de 1999, p. 100-118.

${ }^{78}$ Ibdem.

${ }^{79}$ Ibdem.

${ }^{80}$ ROMEIRO, Adriana. Paulistas e emboabas no coração das Minas: idéias, práticas e imaginário político no século XVIII. Belo Horizonte, MG: Editora UFMG, 2008.
} 
Velho, podemos ver que os paulistas possuíam sua própria visão sobre como conduzir os gentios na América Portuguesa ${ }^{81}$ :

Peço licença para uma breve digressão, nossa milícia senhor é diferente da regular que se observa em todo o mundo. Primeiramente nossas tropas com que imos à conquista do gentio brabo desse vastíssimo sertão, não é de gente matriculada nos livros de V.M. nem obrigada por soldo, nem por pão de munição; são umas agregações que fazemos alguns de nós, entrando cada um com os servos de armas que tem e juntos imos ao sertão deste continente não a cativar (como alguns hipocondríacos pretendem fazer crer a V.M.) senão adquirir o Tapuia gentio brabo e comedor de carne humana para o reduzir ao conhecimento da urbana humanidade, e humana sociedade à associação racional trato, para por esse meio chegarem a ter aquela luz de Deus e dos mistérios da fé católica que lhes basta para sua salvação (porque em vão trabalha, quem os quer fazer anjos, antes de os fazer homens) e desses assim adquiridos, e reduzidos, engrossamos nossas tropas, e com eles guerreamos a obstinados e renitentes a se reduzirem: e se ao depois no servimos deles para as nossas lavouras, nenhuma injustiça lhes fazemos, pois tanto é para os sustentarmos a eles e a seus filhos como a nós e aos nossos: e isto bem longe de os cativar, antes se lhes faz um irremunerável serviço em os ensinar a saberem lavrar, plantar, colher e trabalhar para seu sustento, coisa que antes que os brancos lho ensinem, eles não sabem fazer: isto entendido, senhor?

A forma de negociação utilizada pelos bandeirantes com a Coroa após as diligências no Nordeste foi muito criticada nos escritos antipaulistas ${ }^{82}$. A linguagem direta e a falta de mesuras, comuns ao Antigo Regime, nas petições de mercês e recompensas, suscitaram a desconfiança dos contemporâneos. Em muitos textos, os sertanistas são descritos como meros arrendatários da Coroa, capazes de se aliarem as nações estrangeiras a qualquer momento, caso às gratificações pelos serviços fossem mais palatáveis ${ }^{83}$.

A legenda negra dos homens de Serra Acima foi se constituindo lentamente desde o século XVI. No final dos seiscentos, as representações negativas sobre os paulistas já estavam arraigadas no imaginário social e político do Império luso. Contudo, as opiniões negativas da monarquia portuguesa a cerca da população da Vila de São Paulo não foram construídas somente a partir dos escritos coetâneos. As negociações travadas entre a Coroa e os paulistas desde o século XVI a respeito das recompensas pelas diligências do governo no sertão nordestino colaboraram para a construção de uma relação conflituosa ${ }^{84}$.

\footnotetext{
${ }^{81}$ CARTA autógrafa de Domingos Jorge Velho escrita do Outeiro da Barriga, em 15 de julho de 1694, em que narra os trabalhos e sacrifícios que passou e acompanha a exposição de Bento Sorrel Camiglio, procurador dos paulistas. In ENNES, Ernesto José Bizarro. As guerras nos Palmares: (subsídios para a sua história). São Paulo: Companhia Editora Nacional, 1938.

${ }^{82}$ ROMEIRO, Adriana. Paulistas e emboabas no coração das Minas: idéias, práticas e imaginário político no século XVIII. Belo Horizonte, MG: Editora UFMG, 2008.

${ }^{83}$ Ibdem.

${ }^{84}$ Ibdem.
} 
Especialistas em técnicas de sobrevivência no sertão e habilidosos na arte da guerra, os paulistas realizaram diversas diligências importantes como o combate a Palmares e as Guerras do Açu. Segundo Adriana Romeiro ${ }^{85}$, os sertanistas vangloriavam-se de serem os únicos capazes de enfrentar os perigos dos sertões. Em carta ao Rei, o paulista Domingos Jorge Velho fala sobre o potencial de seu terço ${ }^{86}$ :

[...] hão de dar fim as guerras do Palmar contra os negros e do Açu e Piranhas contra o tapuia como gente mais experiente e versada nessa espécie de guerra irregular, em a qual os cabos mais peritos na disciplina regular não enxergam nada, e só acham nela o desdouro de suas mais de suas mais luzidas (sic) e heróicas façanhas já antes adquiridas.

Apesar de serem reconhecidos pelas autoridades régias como exímios combatentes, os paulistas também causaram grandes problemas para a Coroa. A forma de negociação das recompensas, impetrada pelos sertanistas, era agressiva e totalmente diferente da praticada no Império português. Os paulistas condicionavam seus serviços às recompensas, de modo que, as mercês e as benesses a serem auferidas eram negociadas antes das diligências ${ }^{87}$.

Os moradores de Serra Acima exigiam negociar as remunerações antes dos serviços serem prestados, através dos contratos, como uma forma de garantir o recebimento de mercês e benesses. De certa forma, o descumprimento de promessas em diligências anteriores, por parte da Coroa, contribuiu para essa postura hostil dos sertanistas. Segundo Adriana Romeiro $^{88}$, a lógica de negociação dos paulistas transgredia os padrões políticos da época, porque subvertia a ordem de sujeição e fidelidade do vassalo ao poder régio.

As intrincadas negociações entre a Coroa e os sertanistas tiveram várias conseqüências para as partes. A Coroa, com o passar do tempo, adquiriu um vasto conhecimento sobre a cultura paulista. Esse saber ajudou a monarquia portuguesa a negociar as diligências em busca das jazidas de ouro no sertão da América no final dos seiscentos ${ }^{89}$. Já os paulistas tiveram a

\footnotetext{
${ }^{85}$ ROMEIRO, Adriana. Paulistas e emboabas no coração das Minas: idéias, práticas e imaginário político no século XVIII. Belo Horizonte, MG: Editora UFMG, 2008.

${ }^{86}$ CONDIÇões que os paulistas do terço de infantaria de que é mestre-de-campo Domingos Jorge Velho pedem que se lhe concedam para poder continuar nos Palmares. Apud ROMEIRO, Adriana. Paulistas e emboabas no coração das Minas: idéias, práticas e imaginário político no século XVIII. Belo Horizonte, MG: Editora UFMG, 2008, p. 198.

${ }^{87}$ ROMEIRO, Adriana. A Guerra dos emboabas: novas abordagens e interpretações. In RESENDE, Maria Efigênia Lage de; VILLALTA, Luiz Carlos (Coord.). História das Minas Gerais. As minas setecentistas. Belo Horizonte, MG: Autêntica, Companhia do Tempo, vol. 1, 2007.

${ }^{88} \mathrm{Ibdem}$.

${ }^{89}$ ROMEIRO, Adriana. Revisitando a Guerra dos Emboabas: práticas políticas e imaginário nas Minas setecentistas In BICALHO, Maria Fernanda Baptista; FERLINI, Vera Lúcia Amaral (Coord.). Modos de
} 
legenda negra fortalecida por suas ações. As experiências negativas vividas pelas autoridades régias com os sertanistas, somadas aos escritos antipaulistas, contribuíram para a construção de uma imagem negativa, por parte da Coroa, dos moradores de Vila de São Paulo ${ }^{90}$.

Os paulistas também aprenderam com as longas negociações. Após muitas recompensas prometidas não terem sido cumpridas, os sertanistas passaram a nutrir um sentimento de injustiça em relação à monarquia portuguesa. Para Adriana Romeiro ${ }^{91}$, ocorreu uma fragilização das relações entre o Rei e seus vassalos da Vila de São Paulo, porque os paulistas tinham efetuado as diligências à custa de suas fazendas e esperavam ser devidamente recompensados ${ }^{92}$. Como destacou Domingos Jorge Velho na carta que escreveu ao Rei em $1694^{93}$ :

[...] me fizeram largar a mim e a elas o domicílio que a poder de uma perfiada e diuturna guerra contra o gentio brabo e comedor de carne humana de mais dezesseis anos nos tínhamos conquistado, povoado, lavrado e plantado, com nossas criações e tudo deixamos para virmos servir a V.M. [...].

No final do século XVII, as relações árduas e conturbadas entre Coroa e paulistas tornaram-se um empecilho para a descoberta de riquezas minerais na América portuguesa. Insatisfeitos com as promessas de recompensa não cumpridas, os sertanistas recusavam-se a formalizar os achados minerais porque temiam uma maior vigilância do Estado português e a chegada de estranhos atrás dos metais da região ${ }^{94}$. Além disso, na ilegalidade, os sertanistas não precisavam pagar tributos sobre o ouro, auferindo ganhos maiores ${ }^{95}$.

Atento à lógica paulista, em 1693, o governador da Repartição Sul, Antônio Paes de Sande, relatou à Coroa que, possivelmente, os paulistas conheciam a localização das riquezas

governar: idéias e práticas políticas no Império português, séculos XVI-XIX. São Paulo: Alameda, 2005, p. 392.

${ }^{90}$ Ibdem.

${ }^{91}$ ROMEIRO, Adriana. A Guerra dos emboabas: novas abordagens e interpretações. In RESENDE, Maria Efigênia Lage de; VILLALTA, Luiz Carlos (Coord.). História das Minas Gerais. As minas setecentistas. Belo Horizonte, MG: Autêntica, Companhia do Tempo, vol. 1, 2007.

${ }^{92}$ Ibdem.

${ }^{93}$ CARTA autógrafa de Domingos Jorge Velho escrita do Outeiro da Barriga. 15/07/1694. Apud ROMEIRO, Adriana. Revisitando a Guerra dos Emboabas: práticas políticas e imaginário nas Minas setecentistas. In BICALHO, Maria Fernanda Baptista; FERLINI, Vera Lúcia Amaral (Coord.). Modos de governar: idéias e práticas políticas no Império português, séculos XVI-XIX. São Paulo: Alameda, 2005, p. 395.

${ }^{94}$ ROMEIRO, op. cit.

${ }^{95}$ Ibdem. 
minerais no interior da América portuguesa ${ }^{96}$. No entanto, os sertanistas não manifestavam os achados porque tinham receio da implantação do poder régio na área. Segundo o governador, além dos paulistas zelarem pela liberdade de ação nos sertões, não se sentiam atraídos pelas remunerações oferecidas pela Coroa para oficializarem os achados.

Considerando as argumentações de Antonio Paes de Sande, o Conselho Ultramarino consentiu aos governadores prometerem para os descobridores a posse das minas, mercês e honrarias ${ }^{97}$. A única exigência era o pagamento do quinto à Coroa sobre o metal extraído. Segundo a carta régia de $1694^{98}$ :

\begin{abstract}
Se bem que muitas investigações já tenham sido feitas para o descobrimento das minas, das quais se diz existirem, que todas, porém, não corresponderam às esperanças, principalmente ao tempo do governador D. Afonso Furtado de Mendonça, contudo não deveis negligenciar de prosseguir nessas descobertas, e como as mercês e prêmios sempre animaram os homens a dedicar-se às empresas mais difíceis, prometereis em meu nome carta de nobreza e uma das três ordens militares àquelas pessoas que, de livre vontade, tencionem fazer descobertas de ouro e prata. Os quais, descobrindo uma mina rica, esta pertencerá ao inventor que pagará o quinto ao Real Tesouro como já foi dito. Sem embargo, me reservo determinar se uma mina é rica e se o inventor merece as recompensas prometidas. No caso que se apresentem pessoas que desejam me prestar serviços, deveis animá-las fazendo-lhes esperanças de mercês que se podem esperar da minha generosidade, sem que contudo indiqueis quais sejam.
\end{abstract}

Logo os sertanistas deram notícias do achamento de riquezas minerais no sertão da América $^{99}$. Entretanto, os paulistas viram suas ambições novamente frustradas porque as recompensas prometidas não foram cumpridas. Os sertanistas não receberam a posse das jazidas descobertas. O Estado português, ao invés de conceder a posse das minas aos descobridores, determinou que as terras minerais recém-descobertas deveriam ser repartidas em datas e sorteadas entre os interessados em mineirar no local ${ }^{100}$. A Coroa e o descobridor, respectivamente, tinham direito a uma data que era definida antes do sorteio. Essa forma de divisão prejudicava o descobridor porque ele tinha que escolher a data antes de saber qual era a área que possuía maior quantidade de metais preciosos, ou seja, maior capacidade de

\footnotetext{
${ }^{96}$ ROMEIRO, Adriana. Revisitando a Guerra dos Emboabas: práticas políticas e imaginário nas Minas setecentistas. In BICALHO, Maria Fernanda Baptista; FERLINI, Vera Lúcia Amaral (Coord.). Modos de governar: idéias e práticas políticas no Império português, séculos XVI-XIX. São Paulo: Alameda, 2005. ${ }^{97}$ Ibdem

${ }^{98}$ ESCHWEGE, Wilhelm Ludwig Von. Pluto Brasiliensis. Belo Horizonte: Itatiaia; São Paulo: Edusp, 1979. 2 v. Apud. Ibdem, p.532.

${ }^{99}$ Ibdem

${ }^{100}$ A carta régia de 15 de agosto de 1603 , registrada em 1652 no Rio de Janeiro e em São Paulo, já determinava a divisão dos achados minerais em datas. Essa forma de distribuição vigorou nas Minas durante o século XVIII, porém, sofreu uma série de mudanças para adaptar-se a realidade da nova área de exploração de metais no sertão da América portuguesa. Cf. PAULA, João Antônio de Paula. A mineração de Ouro em Minas Gerais no século XVIII. In RESENDE, Maria Efigênia Lage de; VILLALTA, Luiz Carlos (Coord.). História das Minas Gerais. As minas setecentistas. Vol. 1. Belo Horizonte, MG: Autêntica, Companhia do Tempo, 2007.
} 
produção ${ }^{101}$. Muitas vezes, os descobridores ficavam à míngua porque, sem saber, optavam por terrenos que não possuíam veios auríferos. Além disso, o sorteio das datas abria espaço para os forasteiros participarem da exploração dos minerais. Sobre a repartição das datas, Antonil observou ${ }^{102}$ :

Tem o descobridor a primeira data, como descobridor, e outra como mineiro; segue-se a que cabe a El-Rei, e, atrás desta, a do guarda-mor; as outras se distribuem por sortes. [...] Para ser admitido à repartição por sortes, é necessário fazer petição ao superintendente das ditas repartições, ao qual se dá pelo despacho da petição uma oitava de ouro e outra ao seu escrivão; $\mathrm{e}$ às vezes acontece oferecerem-se quinhentas petições e levarem o repartidor e o escrivão mil oitavas e não tirarem todos os mineiros juntos outro tanto de tais datas, por falharem no seu rendimento; e, por isso, procuram outras datas, havendo descobrimento de novos ribeiros. A data de El-Rei logo se vende a quem mais oferece e pode também qualquer vender ou trocar a sua data; e nisto se viram e vêem a cada passo vários e diferentes sucessos, tirando uns mineiros de poucas braças muito ouro, e outros, de muitas, pouco; e já houve quem por pouco mais de mil oitavas vendeu data, da qual o comprador tirou sete arrobas de ouro. Pelo que se tem por jogo de bem ou mal afortunado, o tirar ou não tirar ouro das datas.

O povo de Serra Acima tentou garantir a posse integral das terras minerais e das sesmarias $^{103}$, argumentando que despenderam muito tempo e sacrificaram suas fazendas em prol dos interesses da Coroa ${ }^{104}$. Mesmo não concedendo o domínio territorial das minas, a Coroa não deixou de reconhecer os préstimos dos sertanistas. Os principais cargos da incipiente estrutura administrativa da área mineradora ficaram nas mãos dos paulistas. Dessa forma, a monarquia portuguesa remunerava e reconhecia os serviços prestados pelos paulistas, sem conferir o domínio permanente das terras da região mineradora.

O desejo da Coroa em recompensar os paulistas por seus serviços estava atrelado à necessidade da monarquia portuguesa de conduzir seus interesses nas minas. Como o Estado Português, no final dos seiscentos, não possuía uma estrutura político-administrativa vigorosa na América portuguesa, capaz de conduzir seus negócios na região mineradora, os paulistas

\footnotetext{
${ }^{101}$ PAULA, João Antônio de Paula. A mineração de Ouro em Minas Gerais no século XVIII. In RESENDE, Maria Efigênia Lage de; VILlALTA, Luiz Carlos (Coord.). História das Minas Gerais. As minas setecentistas. Vol. 1. Belo Horizonte, MG: Autêntica, Companhia do Tempo, 2007.

${ }^{102}$ ANTONIL, Andre João. Cultura e Opulência do Brasil por suas Drogas e Minas. São Paulo: Companhia Editora Nacional, 1967, p. 169.

${ }^{103}$ Após suas intenções de posse das minas terem sido pulverizadas pela monarquia portuguesa, os paulistas ensaiaram obter o controle sobre a concessão das sesmarias na área mineradora e, mais uma vez, malograram na investida. Cf. ROMEIRO, Adriana. A Guerra dos emboabas: novas abordagens e interpretações. In RESENDE, Maria Efigênia Lage de; VILLALTA, Luiz Carlos (Coord.). História das Minas Gerais. As minas setecentistas. Belo Horizonte, MG: Autêntica, Companhia do Tempo, vol. 1, 2007.

${ }^{104}$ Ibdem
} 
apresentavam-se como a melhor alternativa para o governo das minas ${ }^{105}$. O povo de Vila de São Paulo possuía amplo conhecimento da área, domínio das técnicas de exploração dos metais preciosos e grande poder militar na região ${ }^{106}$. No relato do viajante francês François Froger, os paulistas aparecem como grandes exploradores de metais preciosos ${ }^{107}$ :

[...] A propósito desse metal, os paulistas costumam encontrá-lo em tão grande quantidade que o Rei de Portugal, a quem eles enviam o quinto, tira anualmente de 800 a 900 marcos. Eles pagam esse imposto não por medo, já que são mais poderosos que o Rei, mas sim em razão de um costume herdado de seus pais, que, não estando ainda bem estabelecidos nos seus domínios, para se furtarem à dominação dos governadores, alegaram cuidar melhor do que esses dos interesses reais. Segundo dizem os habitantes locais, eles não são súditos do Rei, mas sim tributários; situação que lhes permite livrarem-se desse jugo quando a ocasião for propícia.

No entanto, a predominância de paulistas nos cargos da administração portuguesa nas minas causou grande insatisfação nos recém-chegados. Os forasteiros alegavam que os paulistas eram vassalos infiéis e administravam a região mineradora de forma tirânica ${ }^{108}$.

No final da década de 1700 , as tensões entre paulistas e forasteiros se tornaram cada vez mais acaloradas gerando pequenos incidentes que culminaram no Levante dos Emboabas. Por um lado, os sertanistas, os descobridores das minas, queriam manter seu poder na região. Por outro, os forasteiros viram na expulsão dos paulistas das Minas a possibilidade de obter o domínio político da região mineradora. Esse choque de interesses provocou um conflito que mudou drasticamente a conjuntura político-administrativa da região mineradora.

\subsection{O Levante dos Emboabas}

O Levante dos Emboabas foi um conflito entre paulistas e forasteiros pelo poder nas Minas no início do século XVIII. Os paulistas estavam ali desde o final do XVII e possuíam grande controle político e militar da região. Já os recém-chegados eram mineradores e comerciantes vindos de outras regiões do Império Português no início dos Setecentos. A rivalidade entre os novos e os antigos pelo controle do poder nas minas logo se estabeleceu.

\footnotetext{
${ }^{105}$ ROMEIRO, Adriana. A Guerra dos emboabas: novas abordagens e interpretações. In RESENDE, Maria Efigênia Lage de; VILLALTA, Luiz Carlos (Coord.). História das Minas Gerais. As minas setecentistas. Belo Horizonte, MG: Autêntica, Companhia do Tempo, vol. 1, 2007.

${ }^{106}$ RUSSEL-WOOD, A. J. R. Identidade, etnia e autoridade nas Minas Gerais do século XVIII: leituras do Códice Costa Matoso. in: Varia História, Belo Horizonte, n. 21, julho de 1999, p. 100-118.

${ }^{107}$ FROGER, François. Relation d'un Voyage fait en 1695, 1696 e 1697 aux côtes d'Afrique, Detroit de Magellan, Brésil, Cayenne et Isles Antilles. Amsterdam: Ches lês Héritiers, D’Antoine Schelte, 1699. Apud ROMEIRO, Adriana. Paulistas e emboabas no coração das Minas: idéias, práticas e imaginário político no século XVIII. Belo Horizonte, MG: Editora UFMG, 2008, p.226.

${ }^{108}$ ROMEIRO, op. cit, 2007.
} 
Em 1708, a tensão se transformou em um conflito aberto. O Levante durou três anos e culminou com a ascensão dos forasteiros ao poder e a migração dos paulistas para novas áreas de mineração ${ }^{109}$.

Conforme ressaltei anteriormente, a animosidade entre paulistas e recém-chegados começou desde o início da exploração de riquezas minerais na região central da América portuguesa. Os paulistas almejavam manter o controle político e militar da região mineradora, porém, os recém-chegados logo se tornaram um obstáculo para as intenções sertanistas. Os forasteiros estavam insatisfeitos com o domínio paulista nas Minas e queriam governar a região. Esse choque de interesses entre os grupos gerou uma série de embates no início dos Setecentos e motivou os recém-chegados a travarem um conflito armado para expulsar os sertanistas da região ${ }^{110}$.

Para explicar o Levante dos Emboabas, se faz necessário entender as desavenças que antecederam o conflito e levaram a uma conjuntura social instável nas Minas. Durante a primeira década do XVIII, ocorreram vários incidentes que contribuíram para exaltar as diferenças entre forasteiros e paulistas. Todavia, optei por citar apenas os editais de expulsão do forasteiro Manuel Nunes Viana, publicados pelo paulista Manoel Borba Gato, porque foi este episódio responsável por desencadear o embate armado entre paulistas e forasteiros ${ }^{111}$.

Manoel Borba Gato foi um dos sertanistas mais proeminentes nas Minas. O paulista tinha como uma de suas atribuições no cargo de superintendente das Minas do Poente fiscalizar o caminho entre as minas e a Bahia ${ }^{112}$. De acordo com o regimento de 1702, o comércio direto entre a região baiana e a área mineradora era proibido. Entretanto, os

\footnotetext{
${ }^{109}$ ROMEIRO, Adriana. A Guerra dos emboabas: novas abordagens e interpretações. In RESENDE, Maria Efigênia Lage de; VILLALTA, Luiz Carlos (Coord.). História das Minas Gerais. As minas setecentistas. Belo Horizonte, MG: Autêntica, Companhia do Tempo, vol. 1, 2007.

${ }^{110}$ CÓDICE Costa Matoso. Belo Horizonte: Fundação João Pinheiro, vol. 2, 1999, Coordenação-geral de Luciano Raposo de Almeida Figueiredo e Maria Verônica Campos.

${ }^{111}$ Sobre os outros incidentes: "O clima tenso entre eles (forasteiros e paulistas) havia-se agravado com três incidentes, cujas datas são imprecisas: o assassinato de um negociante português na região do Rio das Mortes, em represália aos maus tratos infligidos à esposa, uma paulista, gerando a suspeita de que o responsável fosse um paulista, o que levou os moradores da região a solicitar garantias ao Governador; no segundo incidente, um português foi acusado de roubar uma espingarda do paulista Jerônimo Pedroso de Barros, numa discussão no adro da igreja do Caeté; o terceiro incidente foi o assassinato de um forasteiro por um mameluco do paulista José Pardo, homem rico e respeitado, que deu homizio ao criminoso, gerando a indignação dos Reinóis, que exigiam a entrega dele. O mameluco foge e o paulista é morto à porta de sua casa, o que leva os paulistas a espalhar o boato de um massacre dos forasteiros em janeiro de 1708." ROMEIRO, Adriana; BOTELHO, Angela Vianna. Dicionário histórico das Minas Gerais: período colonial. $2^{2}$ edição revista. Belo Horizonte, MG: Autêntica, 2004, p.154.

${ }^{112}$ Ibdem.
} 
negócios com a Bahia eram exercidos de maneira ilegal e constituíam uma fonte importante no abastecimento alimentar das minas. Privilegiados pela proximidade geográfica, os mercadores escoavam o gado e os gêneros alimentícios produzidos no Recôncavo baiano e no vale do rio São Francisco para a região mineradora ${ }^{113}$.

Manuel Nunes Viana foi um dos comerciantes mais notáveis no contrabando baiano. O sertanista negociava nas minas, escoltado por muitos homens armados, os bens de primeira necessidade oriundos de suas fazendas de gado e de produção de alimentos no rio São Francisco $^{114}$. Em 1708, o superintendente Borba Gato publicou uma série de editais ordenando a expulsão de Nunes Viana da zona mineradora com a seguinte justificativa ${ }^{115}$ :

[...] não tem mais exercício no Rio de São Francisco que esperar os comboios da Bahia uma grossa sociedade que tem naquela cidade e tanto que lhe chegam não se contenta com marchar com estes para as Minas senão convir servindo de capitania aos mais comboios para que nenhum seja tomado do inimigo que nesta conta tem a quem trata da arrecadação da Fazenda de Sua Majestade. [...].

Para o superintendente, Manuel Nunes Viana estava lesando gravemente a Coroa e, por isso, determinou sua saída das Minas. Em carta a Borba Gato, o forasteiro se negou a sair da região mineradora, argumentando que as culpas que o superintendente atribuía a ele eram descabidas ${ }^{116}$. Além disso, Viana contestou a autoridade de Borba Gato para expulsá-lo alegando que a entrada nas Minas era livre ${ }^{117}$ :

Em um diz V. M. ser minha vinda prejudicial à Fazenda de el Rei meu senhor o que me nego
mas antes lhe dou aumento por quanto multiplica a quantidade dela a minha pouca idade e V.
M. pela lei não pode impedir a entrada e saída nestas Minas nem a pessoa alguma por
portugueses e vassalos todos de um senhor menos o pode V. M. impedir que um ministro
substabelecido por outrem e ninguém mais que vem e todos aqueles que se chamam emboabas
obedientes a todas as ordens de S. Mag. ${ }^{\text {de }}$ q. ${ }^{e}$ D. ${ }^{\mathrm{s}}$ g. ${ }^{\mathrm{e}}[\ldots]$ Consta a outra dizer que sou cabeça de
motins o que não depende de negativa pois se sabe a meu viver que faço estudo das razões para
sempre apaziguar como consta o tenho por costume no Rio de São Francisco donde é minha
Capitania, e em todo ele conservo o povo com razão e quietação e o mesmo faço donde quer
que me acho.

${ }^{113}$ ROMEIRO, Adriana. A Guerra dos emboabas: novas abordagens e interpretações. In RESENDE, Maria Efigênia Lage de; VILLALTA, Luiz Carlos (Coord.). História das Minas Gerais. As minas setecentistas. Belo Horizonte, MG: Autêntica, Companhia do Tempo, vol. 1, 2007.

${ }^{114}$ CÓDICE Costa Matoso. Belo Horizonte: Fundação João Pinheiro, vol. 2, 1999, Coordenação-geral de Luciano Raposo de Almeida Figueiredo e Maria Verônica Campos.

${ }^{115}$ AHU, Cons. Ultra. Brasil/RJ, doc. 3214. CARTA de Borba Gato ao governador da capitania D. Fernando Martins Mascarenhas de Lencastre. Minas do Rio das Velhas, 29/11/1708. Apud ROMEIRO, op. cit.

${ }^{116}$ CÓDICE Costa Matoso. Belo Horizonte: Fundação João Pinheiro, vol. 2, 1999, Coordenação-geral de Luciano Raposo de Almeida Figueiredo e Maria Verônica Campos.

${ }^{117}$ CARTA de Manoel Nunes Viana a Manoel Borba Gato, 13/10/1708. Apud BORREGO, Maria Aparecida de Menezes. Códigos e práticas: o processo de constituição urbana em Vila Rica colonial (1702-1748). São Paulo: Annablume, 2004, p. 91. 
Descontentes com a atitude do superintendente paulista, os forasteiros uniram-se e elegeram Manuel Nunes Viana como governador das Minas afrontando a autoridade de Borba Gato e deflagrando um conflito aberto com os sertanistas.

É importante ressaltar que os recém-chegados, ao eleger Manuel Nunes Viana, não tinham a intenção de sobrepor à autoridade do governador do Rio de Janeiro, São Paulo e Minas, D. Fernando Martins Mascarenhas de Lencastre ${ }^{118}$. Os forasteiros almejavam criar uma autoridade com maior poder na região mineradora do que os paulistas tinham nos cargos ocupados na administração portuguesa. Essa premissa era essencial porque os recémchegados contestavam a autoridade dos sertanistas nas Minas, mas, não desejavam opor-se à autoridade da Coroa. Ao contrário, os forasteiros ensejavam participar da estrutura políticoadministrativa portuguesa na área mineradora como vassalos leais ${ }^{119}$. Além disso, os recémchegados tentaram legitimar a eleição de Nunes Viana como governador baseados no direito do povo de depor um governo tirânico. No escrito coevo, o autor anônimo discorre sobre a legitimidade da eleição de Nunes Viana ${ }^{120}$ :

\begin{abstract}
Vendo os reinóis que desagregados de Manuel Nunes Viana poderiam ser enxovalhados pelos paulistas, resolveram-se a aclamar por seu governador ao dito Viana, o que logo aceitou, com juramento de bem os governar e de defendê-los do rigor dos paulistas. E tomando posse do governo, que lha deram na forma do estilo, ficou sendo legitimamente governador das Minas por eleição e aceitação do povo, [...], e desta forma ficou temido dos paulistas, e os refreou de algum modo dos seus insultos, e os fez retirar para as suas fazendas de São Paulo.
\end{abstract}

O conceito de direito de contestação que os recém-chegados se valiam advinha dos escritos portugueses de filosofia e política do século XVII ${ }^{121}$ e também do pensamento propagado pós-restauração portuguesa. Luciano Figueiredo ${ }^{122}$ coloca que, após a restauração de 1640, ocorreu uma transformação política em Portugal, ampliando as possibilidades de mudança política.

\footnotetext{
${ }^{118}$ CÓDICE Costa Matoso. Belo Horizonte: Fundação João Pinheiro, vol. 2, 1999, Coordenação-geral de Luciano Raposo de Almeida Figueiredo e Maria Verônica Campos.

${ }^{119}$ ROMEIRO, Adriana. Paulistas e emboabas no coração das Minas: idéias, práticas e imaginário político no século XVIII. Belo Horizonte, MG: Editora UFMG, 2008.

${ }^{120}$ NOTÍCIAS dos primeiros anos das Minas Gerais. Relação de algumas antiguidades das Minas, 13/12/1946. In CÓDICE, op. cit, p. 223.

${ }^{121}$ CALAFATE, Pedro. A reflexão portuguesa sobre a política nos séculos XVI e XVII. In História do pensamento filosófico português. Vol. 2. Lisboa: Caminho, 1999, p. 663-700.

${ }^{122}$ FIGUEIREDO, Luciano. Tradições Radicais: aspectos da cultura política mineira setecentista. In RESENDE, Maria Efigênia Lage de; VILLALTA, Luiz Carlos (Coord.). História das Minas Gerais. As minas setecentistas. Belo Horizonte: Autêntica, Companhia do Tempo, vol. 1, 2007.
} 
Para Figueiredo ${ }^{123}$, o dever dos súditos era obedecer às ordens reais, entretanto, quando um dos atributos desejáveis em um Rei não era cumprido, como a justiça, o governo tornava-se ilegítimo. Nesse caso, os vassalos tinham o direito de substituir o governante tirano em nome do bem comum porque o poder emana do povo, ou seja, os súditos concedem a autoridade para o Rei governá-los, desde que ele aja conforme os atributos que lhe são imputados $^{124}$. Essa ideia reverberou na América Portuguesa e foi usada para legitimar diversos conflitos, pois, os oficiais régios eram representantes da monarquia portuguesa na colônia e deveriam administrar de acordo com as qualidades desejáveis em um Rei ${ }^{125}$.

Para os forasteiros, os paulistas administravam os negócios do Rei de forma arbitrária e tirânica, desconsiderando a principal característica necessária a todo governante: a justiça. Com essa justificativa, Manuel Nunes Viana foi proclamado governador das Minas, um cargo novo, sob o manto da Coroa Portuguesa, mas, capaz de destituir os paulistas que usurpavam o poder real ao não agir de acordo com os critérios esperados de um bom governante.

Também é notável o esforço dos forasteiros em dar uma aparência de legalidade à eleição de Viana quando observamos a condução dos interesses da Coroa nas Minas pelos recém-chegados após a proclamação do novo governador ${ }^{126}$. Manuel Nunes Viana, ao assumir seu posto, nomeou os forasteiros para os cargos da administração portuguesa e não modificou a forma de execução das leis em vigor na região mineradora estipulada pela monarquia portuguesa. Isso sugere, mais uma vez, que o grupo liderado por Viana aceitava o governo metropolitano, porém, discordava da forma como os paulistas o exerciam.

A partir da proclamação de Manuel Nunes Viana como governador, em 1708, o conflito armado entre as partes se instaurou. Os paulistas de diversas áreas da região mineradora reuniram-se em Sabará porque o lugar oferecia fácil acesso a muitos arraiais mineiros e a zona litorânea. Já os forasteiros, sob o comando de Manuel Nunes Viana, empreenderam uma série de arruaças nas imediações de Sabará para expulsar os sertanistas,

\footnotetext{
${ }^{123}$ FIGUEIREDO, Luciano. Tradições Radicais: aspectos da cultura política mineira setecentista. In RESENDE, Maria Efigênia Lage de; VILLALTA, Luiz Carlos (Coord.). História das Minas Gerais. As minas setecentistas. Belo Horizonte: Autêntica, Companhia do Tempo, vol. 1, 2007. p.254.

${ }^{124}$ CÓDICE Costa Matoso. Belo Horizonte: Fundação João Pinheiro, vol. 2, 1999, Coordenação-geral de Luciano Raposo de Almeida Figueiredo e Maria Verônica Campos.

${ }^{125}$ FIGUEIREDO, op. cit., p.254.

${ }^{126}$ ROMEIRO, Adriana. A Guerra dos emboabas: novas abordagens e interpretações. In RESENDE, Maria Efigênia Lage de; VILLALTA, Luiz Carlos (Coord.). História das Minas Gerais. As minas setecentistas. Belo Horizonte, MG: Autêntica, Companhia do Tempo, vol. 1, 2007.
} 
obrigando os paulistas a fugir ${ }^{127}$. Durante três anos, uma série de batalhas entre os antigos e os novos ocorreu nas Minas sendo, segundo os contemporâneos, o Capão da Traição considerado o mais violento ${ }^{128}$. No escrito coetâneo História do Rio das Mortes, podemos ver a descrição desse episódio como um dos mais sangrentos ${ }^{129}$ :

[...] certos os paulistas da chegada desta gente (forasteiros) logo se dividiram em mangas e buscaram, com muita pressa, as emboscadas dos matos. E sabendo-se que uma destas se tinha metido da outra parte do Rio das Mortes, coisa de légua e meia ao rumo do Norte, em um capão, nome que pelos naturais se dá a qualquer porção de mato, maior ou menor, sendo separado, por todas as partes, de outro mato, com um cabo Manuel de Góes, insolentíssimo e blasfemo da Majestade, o dito Amaral passou o Rio com a sua gente, alguma do arraial. E chegando a vista por sítio ao dito capão e os paulistas como nada temiam pegaram nas armas, deram tiros e feriram alguns emboabas, causa porque os mais, cheios de cólera, apertaram o cordão e ganhado o mato puseram os paulistas as armas em terra e pediram quartel, sendo levados à presença do Comandante foram mortos a sangue frio.

Os grupos possuíam estilos de combate distintos ${ }^{130}$. Os paulistas tinham maior conhecimento do território, lutavam ofensivamente e possuíam uma estrutura de comando mais fraca. Também tinham predileção pela guerra de caráter individual. Já os forasteiros possuíam maior poder bélico, batalhavam, geralmente, na defensiva, estruturados em flancos e de forma mais centralizada.

Devido à investida violenta contra os paulistas no Capão da traição, em 1709, D. Fernando Martins de Lencastre infringiu a determinação da Coroa que proibia o governador da capitania de partir para as Minas sem autorização régia prévia ${ }^{131}$. Ao chegar às Minas, o governador foi recebido de forma hostil pelos forasteiros e malogrou na tentativa de pacificar a região, voltando às pressas para o Rio de Janeiro após ameaças.

\footnotetext{
${ }^{127}$ ROMEIRO, Adriana. A Guerra dos emboabas: novas abordagens e interpretações. In RESENDE, Maria Efigênia Lage de; VILLALTA, Luiz Carlos (Coord.). História das Minas Gerais. As minas setecentistas. Belo Horizonte, MG: Autêntica, Companhia do Tempo, vol. 1, 2007.

${ }^{128}$ CÓDICE Costa Matoso. Belo Horizonte: Fundação João Pinheiro, vol. 2, 1999, Coordenação-geral de Luciano Raposo de Almeida Figueiredo e Maria Verônica Campos, p. 154.

${ }^{129}$ HISTÓRIA do Rio das Mortes, sua descrição, descobrimento das suas minas, casos neles acontecidos entre paulistas e emboabas e ereção de suas vilas. In Idem, p. 233-234.

${ }^{130}$ RUSSEL-WOOD, A. J. R. Identidade, etnia e autoridade nas Minas Gerais do século XVIII: leituras do Códice Costa Matoso. in: Varia História, Belo Horizonte, n. 21, julho de 1999, p. 100-118.

${ }^{131}$ CÓDICE, op. cit.
} 
Depois do insucesso de sua empreitada, Lencastre foi substituído por Antônio de Albuquerque Coelho e Carvalho. Na carta de nomeação do novo governador, o Rei destaca a necessidade de pacificar os povos das Minas ${ }^{132}$ :

[...] e vos encarrego muito que façais entender aqueles vassalos que este Regimento não é para os conquistar, porque estou certo na obediência que têm, a fidelidade que devem guardar a seu príncipe, mas que é para defender de violências, e conservar em paz, e justiça, que é a primeira obrigação do Rei, e os persuadireis a se abstraírem dos delitos, que cometem, e viverem como católicos, obedecendo as minhas ordens e aos ministros, por que lhes mando administrar a justiça, que os hei de premiar, e honrar conforme o seu merecimento, e aos obrarem em o meu serviço, e os que mais sinalaram nele ficarão na minha real lembrança de que sereis obrigado a informar ele muito particularmente.

Antônio de Albuquerque Coelho e Carvalho, como governador do Estado do Maranhão (1685-1690) e do Grão-Pará (1690-1701), tinha realizado muitas viagens de inspeção ao Amazonas e ao rio Negro ${ }^{133}$. Portanto, o novo governador da capitania era mais experiente na administração do América Portuguesa. Logo que assumiu a capitania do Rio de Janeiro, Minas Gerais e São Paulo, Carvalho viajou secretamente para as Minas a fim de solucionar o conflito que se arrastava, há três anos, na região mineradora ${ }^{134}$.

Quando chegou às Minas, Carvalho, inteirado sobre a situação conturbada, ordenou que Manuel Nunes Viana deixasse a região mineradora e o forasteiro assim o fez. Também concedeu perdão aos levantados e confirmou os recém-chegados nos cargos nomeados por Viana. Percebe-se que a Coroa viu no Levante dos Emboabas uma oportunidade de diminuir a proeminência dos paulistas na região mineradora ${ }^{135}$.

Conforme o debate que apresentei, a monarquia portuguesa não se identificava com os paulistas devido o modo de negociar as recompensas das diligências no nordeste nos dois primeiros séculos de colonização e os escritos antipaulistas. Já os forasteiros, durante o

\footnotetext{
${ }^{132}$ Revista do Arquivo Público Mineiro. Ano XI, 1906, p.668. NOMEAÇÃO de Antônio de Albuquerque.

${ }^{133}$ RUSSEL-WOOD, A. J. R. Identidade, etnia e autoridade nas Minas Gerais do século XVIII: leituras do Códice Costa Matoso. in: Varia História, Belo Horizonte, n. 21, julho de 1999, p. 100-118.

${ }^{134}$ Ibdem, p. 100-118.

${ }^{135}$ CÓDICE Costa Matoso. Belo Horizonte: Fundação João Pinheiro, vol. 2, 1999, Coordenação-geral de Luciano Raposo de Almeida Figueiredo e Maria Verônica Campos.
} 
Levante dos Emboabas, tiveram como uma de suas estratégias trazerem a Coroa para o seu lado através da revitalização da legenda negra ${ }^{136}$.

Segundo Adriana Romeiro ${ }^{137}$, os recém-chegados instrumentalizaram o discurso antipaulista para desqualificar a imagem dos sertanistas nas Minas perante a monarquia portuguesa. Nas cartas ao Rei, os forasteiros não questionavam o direito de conquista dos paulistas, mas, colocavam em dúvida a capacidade dos sertanistas de conduzir os interesses da Coroa na região mineradora. Os forasteiros alegavam que os paulistas eram nômades e não tinham apreço pelo bom governo. Para a autora ${ }^{138}$, essa tática funcionou e logo o Conselho Ultramarino confirmou as ordens de Antônio Albuquerque Coelho e Carvalho, privilegiando assim os forasteiros.

É fundamental tecer algumas considerações sobre o fim do Levante dos Emboabas e seus desdobramentos. De certa forma, as dissidências entre os forasteiros e a insatisfação popular com o governo de Manuel Nunes Viana contribuíram para o sucesso de Antônio de Albuquerque Coelho e Carvalho na pacificação do Levante.

Os forasteiros não constituíam um conjunto homogêneo. O grupo não possuía uma identidade específica como os paulistas. Segundo Russel-Wood ${ }^{139}$, a união dos recémchegados foi forjada no abismo cultural que os separava dos sertanistas. O não-paulista foi denominado como forasteiro e nesta alteridade baseou-se a união dos recém-chegados. Entretanto, entre os forasteiros, existiam inúmeras diferenças. Após a migração dos paulistas para as novas áreas de povoamento, essas desavenças entre os forasteiros ficaram mais evidentes gerando o enfraquecimento do poder de Manuel Nunes Viana na área central da região mineradora ${ }^{140}$.

O sucesso de Carvalho e a diminuição do poder de Manuel Nunes Viana no fim do Levante dos Emboabas também estão atrelados com o descontentamento da população com o governo do comerciante, que almejava impor um monopólio de açougues nas minas

\footnotetext{
${ }^{136}$ ROMEIRO, Adriana. A Guerra dos emboabas: novas abordagens e interpretações. In RESENDE, Maria Efigênia Lage de; VILLALTA, Luiz Carlos (Coord.). História das Minas Gerais. As minas setecentistas. Belo Horizonte, MG: Autêntica, Companhia do Tempo, vol. 1, 2007.

${ }^{137}$ Ibdem.

${ }^{138}$ Ibdem.

${ }^{139}$ RUSSEL-WOOD, A. J. R. Identidade, etnia e autoridade nas Minas Gerais do século XVIII: leituras do Códice Costa Matoso. in: Varia História, Belo Horizonte, n. 21, julho de 1999, p. 100-118.

${ }^{140}$ ROMEIRO, op. cit.
} 
considerado abusivo $^{141}$. Todavia, essa fragilização do poder de Viana foi localizada porque o comerciante não perdeu seu prestígio na região do Vale do São Francisco. Muito ao contrário, em 1718, na companhia do Padre Antônio Ávila Curvelo, Viana foi um líderes do motim de barra do Rio das Velhas, que era contra o estabelecimento de uma passagem na região e a elevação do arraial dos Papagaios a Vila ${ }^{142}$.

A expulsão dos paulistas da região central das Minas também é outro ponto importante na análise do fim do Levante dos Emboabas. Apesar dos forasteiros terem auferido cargos e maior prestígio junto a Coroa, não conseguiram afastar os sertanistas da região ${ }^{143}$. Os paulistas adentraram no território colonial luso e descobriram novas zonas de mineração. Um exemplo disso é o estabelecimento do arraial de Pitangui, na comarca do Rio das Velhas, após o conflito ${ }^{144}$.

Segundo Carla Anastasia ${ }^{145}$, Pitangui se tornou o novo reduto dos sertanistas na região mineradora. Os paulistas tentaram de múltiplas formas se isolarem do governo das Minas com receio de terem suas atividades controladas pelas autoridades locais. A fim de evitar os caminhos controlados pelo governo das Minas, logo no início da ocupação os sertanistas construíram um caminho que ligava o novo arraial direto a São Paulo. Entretanto o isolamento de Pitangui durou pouco tempo porque, em 1715, o arraial foi elevado a Vila de Nossa Senhora da Piedade de Pitangui com o intuito de estabelecer as estruturas do Estado luso na área e, principalmente, a cobrança do quinto ${ }^{146}$.

Em 1717, o novo governador, D. Pedro Miguel de Almeida, o Conde de Assumar, resolveu instaurar a cobrança do quinto na região. Insatisfeita, a população, liderada pelo sertanista Domingos Rodrigues do Prado levantou-se contra o poder da Coroa portuguesa, negando-se a aceitar a jurisdição dos oficiais régios na área e a arrecadação do quinto. Os motins de Pitangui duraram entre 1717 e 1719, provocando diversos assassinatos de

\footnotetext{
${ }^{141}$ ROMEIRO, Adriana. A Guerra dos emboabas: novas abordagens e interpretações. In RESENDE, Maria Efigênia Lage de; VILLALTA, Luiz Carlos (Coord.). História das Minas Gerais. As minas setecentistas. Belo Horizonte, MG: Autêntica, Companhia do Tempo, vol. 1, 2007.

${ }^{142}$ ANASTASIA, Carla Maria Junho. Vassalos Rebeldes: violência coletiva nas Minas na primeira metade do século XVIII. Belo Horizonte: C/Arte, 1998.

${ }^{143}$ RUSSEL-WOOD, A. J. R. Identidade, etnia e autoridade nas Minas Gerais do século XVIII: leituras do Códice Costa Matoso. in: Varia História, Belo Horizonte, n. 21, julho de 1999, p. 100-118.

${ }^{144}$ ANASTASIA, Carla Maria Junho. Vassalos Rebeldes: violência coletiva nas Minas na primeira metade do século XVIII. Belo Horizonte: C/Arte, 1998.

${ }^{145}$ Ibdem.

${ }^{146}$ Ibdem.
} 
autoridades régias e paulistas favoráveis a cobrança do imposto na região ${ }^{147}$. Pelos motins de Pitangui, é perceptível que os reveses da monarquia portuguesa com os paulistas nas Minas não cessaram com o fim do Levante dos Emboabas.

Para a Coroa, o resultado do conflito entre forasteiros e paulistas foi uma solução temporária. O fim do Levante dos Emboabas representou a ascensão de um grupo que vinha tentando se estabelecer nas Minas desde o início do século XVIII ${ }^{148}$. Ocorreu na região mineradora uma substituição nas estruturas de poder que possibilitou o gradual estabelecimento político-administrativo da Coroa Portuguesa.

Depois da pacificação do Levante dos Emboabas, D. Antônio de Albuquerque encetou um processo de estabelecimento do aparelho político-administrativo português. É nesse ensejo que se encontra a instalação das primeiras câmaras nas Minas ${ }^{149}$. Entre 1711 e 1718, foram erigidas as seguintes vilas e suas respectivas municipalidades: Ribeirão do Carmo, Vila Rica, Sabará, São João del-Rei, Caeté, Serro Frio, Pitangui e São José ${ }^{150}$. Contudo, os forasteiros logo se tornaram uma ameaça aos interesses do Império Luso. Um exemplo disso é a Sedição de Vila Rica que será tratada no próximo capítulo.

Segundo Adriana Romeiro ${ }^{151}$, os recém-chegados afugentaram os paulistas da área central da região mineradora ao promover um discurso de submissão incondicional à monarquia portuguesa e manipular a legenda negra a seu favor. Todavia, após o Levante dos Emboabas a Coroa se tornou o novo concorrente aos interesses dos forasteiros.

\footnotetext{
${ }^{147}$ ANASTASIA, Carla Maria Junho. Vassalos Rebeldes: violência coletiva nas Minas na primeira metade do século XVIII. Belo Horizonte: C/Arte, 1998.

${ }^{148}$ KELMER MATHIAS, Carlos Leonardo. Jogos de interesses e redes clientelares na revolta mineira de Vila Rica (c. 1709 - c. 1736). Rio de Janeiro: UFRJ, PPGHIS, 2005.

${ }^{149}$ GOUVÊA, Maria de Fátima da Silva. Dos poderes de Vila Rica do Ouro Preto: notas preliminares sobre a organização político-administrativa na primeira metade do século XVIII. Revista Varia História, Belo Horizonte, $\mathrm{n}^{\mathrm{o}}$ 31, p. 120-140, Jan/Jun 2004.

${ }^{150}$ CAMPOS, Maria Verônica. Governo de mineiros: "de como meter as Minas numa moenda e beber-lhe o caldo dourado" 1693 a 1737. São Paulo: USP, FFLCH, 2002.

${ }^{151}$ ROMEIRO, Adriana. A Guerra dos emboabas: novas abordagens e interpretações. In RESENDE, Maria Efigênia Lage de; VILLALTA, Luiz Carlos (Coord.). História das Minas Gerais. As minas setecentistas. Belo Horizonte, MG: Autêntica, Companhia do Tempo, vol. 1, 2007.
} 
De acordo com Romeiro ${ }^{152}$, os recém-chegados deixaram de lado o discurso de fidelidade irrestrita à monarquia portuguesa, usado no Levante dos Emboabas. Eles incorporaram a noção de direito de conquista impetrada pelos sertanistas nas negociações com a Coroa, desde o século XVI. No entanto, os recém-chegados utilizaram uma nova base argumentativa para reivindicar mercês e benesses junto a Coroa. Os forasteiros passaram a alegar que, ao expulsar os paulistas das Minas, tinham pacificado a região mineradora e, portanto, mereciam auferir mercês e benesses. O resultado do Levante dos Emboabas se tornou a nova moeda de troca dos recém-chegados com a monarquia portuguesa. ${ }^{153}$

${ }^{152}$ ROMEIRO, Adriana. A Guerra dos emboabas: novas abordagens e interpretações. In RESENDE, Maria Efigênia Lage de; VILLALTA, Luiz Carlos (Coord.). História das Minas Gerais. As minas setecentistas. Belo Horizonte, MG: Autêntica, Companhia do Tempo, vol. 1, 2007.

${ }^{153}$ Ibdem. 


\section{CAPÍTULO 2}

A CÂMARA DE VILA RICA E A SEDIÇÃO DE 1720 
O presente capítulo tem como foco principal a discussão historiográfica sobre as principais características da municipalidade Vilariquenha, sua atuação durante a primeira metade do século XVIII e as mudanças ocorridas na Câmara após a Sedição de Vila Rica em 1720. Esse debate é imprescindível para entendermos como se deu o processo de estabelecimento do poder da Câmara Vilariquenha, em meio às revoltas ocorridas no período tratado.

Na parte inicial do capítulo, A ereção da Câmara Vilariquenha, abordo as principais características que as municipalidades adquiriram nas Minas, destacando as ações da Câmara de Vila Rica. Na segunda parte, Sedição de Vila Rica, 1720, descrevo o conflito e seus desdobramentos nos governos ulteriores. Na última parte do capítulo, O governo de D. Lourenço de Almeida e a pacificação das Minas, procuro evidenciar como a Sedição de Vila Rica contribuiu para a estabilidade de D. Lourenço de Almeida no governo da capitania das Minas.

\subsection{A ereção da Câmara Vilariquenha}

As municipalidades no Império ultramarino foram imprescindíveis para a manutenção do poder da Coroa portuguesa nas colônias ${ }^{154}$. Essa instituição transladada do Reino para o ultramar adquiriu características particulares no Império português ${ }^{155}$, constituindo-se muitas vezes, em espaço de resistência às ordens régias. A Câmara de Vila Rica é um exemplo disso.

Conforme destaquei no primeiro capítulo desta dissertação, a criação das primeiras câmaras na região central da América lusa se inseria no projeto da Coroa de implantar as estruturas política e administrativa do Estado português nas Minas ${ }^{156}$. A municipalidade Vilariquenha foi criada no dia oito de julho de 1711 com o nome de Vila Rica do

\footnotetext{
${ }^{154}$ BICALHO, Maria Fernanda. A cidade e o império: o Rio de Janeiro no século XVIII. Rio de Janeiro: Civilização Brasileira, 2003.

${ }^{155}$ HESPANHA, Antonio Manuel. As vésperas do Leviathan. Instituições e poder político. Portugal. Séc. XVII. Coimbra: Livraria Almedina, 1994. 9

${ }^{156}$ GOUVÊA, Maria de Fátima da Silva. Dos poderes de Vila Rica do Ouro Preto: notas preliminares sobre a organização político-administrativa na primeira metade do século XVIII. Revista Varia História, Belo Horizonte, $\mathrm{n}^{\mathrm{o}} 31$, p. 120-140, Jan/Jun 2004.
} 
Albuquerque $^{157}$. O nome foi alterado para Vila Rica do Ouro Preto antes de sua primeira vereação que ocorreu no dia 21 de julho de 1711.

Para compor os quadros de oficiais da primeira Câmara, o governador reuniu os homens bons de Vila Rica em Junta Geral e ficou decidido que a municipalidade seria composta por: três vereadores, um procurador, um escrivão e, devido a ausência do cargo de juiz de fora nas Minas no início da instituição da municipalidade, dois juízes ordinários. Também ficou estipulado que as eleições para os cargos camarários seriam anuais.

Fernanda Fioravante ${ }^{158}$ coloca que, para ser eleito a um dos cargos da Câmara era necessário passar por um complexo processo eleitoral que aliava a cooptação da aristocracia, o voto aristocrático e a sorte. Foram eleitos para primeira governação: o coronel José Gomes de Melo como juiz mais velho, Fernando Fonseca e Sá como juiz mais moço, Manuel de Figueiredo Mascarenhas como vereador mais velho, Felix de Gusmão Mendonça Bueno como segundo vereador, Antônio de Faria Pimentel como terceiro vereador, e o capitão Manuel de Almeida Costa como procurador ${ }^{159}$.

Segundo Maria de Fátima da Silva Gouvêa ${ }^{160}$, a municipalidade Vilariquenha ficou responsável por dar prosseguimento ao processo de construção da vida político-administrativa no território sob sua jurisdição. A cobrança e controle dos tributos, arrematação de contratos, determinação dos pesos e medidas, controle do abastecimento alimentar e da prática dos ofícios mecânicos, controle das cadeias, assistência filantrópica, ordenamento urbano e a promoção de festividades e cerimônias, foram algumas das incumbências imputadas às câmaras. Além de normatizar o cotidiano das Minas, as câmaras tinham a função de mediar à relação entre o Estado português e seus vassalos ${ }^{161}$.

\footnotetext{
${ }^{157}$ Atas da Câmara Municipal de Ouro Preto (1711-1715). Anais da Biblioteca nacional. 1927. v. 49, p. 201. Auto de ereção da Vila com o nome de Vila Rica D'Albuquerque e criação da Câmara, 08/07/1711.

${ }^{158}$ FIORAVANTE, Fernanda “Às custas do sangue, fazenda e escravos": formas de enriquecimento e padrão de ocupação dos ofícios da Câmara de Vila Rica, c. 1711 - c. 1736. Rio de Janeiro: UFRJ, PPGHIS, 2008.

${ }^{159}$ Atas da Câmara Municipal de Ouro Preto (1711-1715), op. cit.

${ }^{160}$ GOUVÊA, Maria de Fátima da Silva. Dos poderes de Vila Rica do Ouro Preto: notas preliminares sobre a organização político-administrativa na primeira metade do século XVIII. Revista Varia História, Belo Horizonte, $n^{\circ} 31$, p. 120-140, Jan/Jun 2004.

${ }^{161}$ Ibdem.
} 
A instalação das municipalidades nas Minas também supria a necessidade da monarquia portuguesa de reforçar simbolicamente seu poder junto aos vassalos da região mineradora. Uma das atribuições das câmaras era promover celebrações e festividades. Esses eventos contribuíam para lembrar os súditos do laço que os unia ao Rei, justo e magnânimo, que zelava pelo bem-estar dos seus vassalos mesmo distante. Por exemplo, em 1727, D. João V solicitou ao governador das Minas, D. Lourenço de Almeida, que recolhesse donativos das câmaras e da população da capitania para os casamentos do seu filho, José I, com a infanta Ana Vitória de Espanha e do príncipe das Astúrias, Fernando VI, com sua filha, a infanta Maria Bárbara ${ }^{162}$ :

[...] me pareceu dizer-vos que sendo preciso fazerem-se grandes despesas nas ocasiões destes matrimônios além do dote que tenho prometido a Infante minha filha e achando-se os Vassalos deste Reino atenuados com os tributos que pagaram por ocasião da guerra passada, [...] será necessário que os povos dessa Capitania concorram com um considerável donativo e assim sou servido que logo que receberdes esta carta manifestei aos moradores desse governo e Câmaras dele a obrigação que lhes ocorre para se forçarem a contribuir com um bom donativo para com ele suprir a maior parte das ditas despesas e dote, igualando este donativo o bom ânimo que sempre mostraram e a vontade e amor que lhes tenho, [...] devem mostrar a sua lealdade e gosto com que recebem esta tão plausível notícia, certificando-os que terei muito na lembrança o zelo com que espero me sirvam neste particular com a eficácia que pede a sua importância $[\ldots]$.

O monarca justificou o pedido destacando que os súditos do Reino se encontravam pesadamente onerados devido aos gastos com a Guerra de Sucessão Espanhola e que era obrigação dos povos das Minas contribuírem para o matrimônio dos herdeiros do trono. D. João $\mathrm{V}$ também reforçou seu argumento apelando para a lealdade dos súditos que demonstrariam sua fidelidade ao Rei ao dar um bom donativo.

No outro ano, o Rei enviou carta ao governador das Minas comunicando a realização dos enlaces e pedindo que fossem promovidas as devidas festividades na região mineradora $^{163}$ :

[...] sendo estas notícias de tão grande contentamento para todos os meus vassalos é justo que como tais se festejem com todas as demonstrações de alegria que forem possíveis. Vos ordeno que nesta Capitania se façam salvas e luminárias e o mais que é costume em semelhantes ocasiões.

\footnotetext{
${ }^{162}$ SOBRE estas Minas contribuírem com um donativo para as despesas dos casamentos de suas altezas. Carta de D. João V a D. Lourenço de Almeida, 12/04/1727. In TRANSCRIÇÃO da primeira parte do Códice 23 - Seção Colonial. Registro de Alvarás, cartas e ordens régias e cartas do Governador ao Rei, 1721-1731. Revista do Arquivo Público Mineiro. Ano XXX, 1979, p. 117-278, p. 265-266.

${ }^{163}$ SOBRE se festejarem nestas Minas os casamentos de suas altezas. Carta de D. João V a D. Lourenço de Almeida, 15/01/1728. In Ibdem, p. 267.
} 
A importância dada à comemoração dos casamentos no ultramar demonstra a necessidade que a Coroa tinha em fortalecer, constantemente, os laços com seus súditos ${ }^{164}$. Além disso, ao solicitar que fossem realizadas nas Minas festividades comuns às praticadas nessas ocasiões no Reino, o Rei incorporava ao cotidiano da colônia elementos culturais advindos da Europa, reforçando a presença portuguesa no espaço ultramarino e o vínculo com seus vassalos.

Os oficiais camarários também eram beneficiados durante as festas e rituais porque aumentavam seu prestígio dentro da sociedade mineradora e recebiam propinas para participar dos eventos. Para Camila Fernanda Guimarães Santiago ${ }^{165}$, vários embates políticos entre camarários, governadores e ouvidores foram provocados por abusos cometidos pelos oficiais das câmaras no recebimento das propinas e emolumentos para as festividades e cerimônias. Os ouvidores e governadores questionavam os constantes desvios nos emolumentos para as comemorações e rituais e o alto valor pago em propinas para a participação dos camarários nesses eventos, originando conflitos entre as autoridades das Minas ${ }^{166}$.

Segundo Maria Aparecida Borrego ${ }^{167}$, a questão urbana também desencadeou momentos de tensão nas Minas entre a população, os oficiais régios e os camarários. As municipalidades tinham a incumbência de controlar e promover a conformação do território sob sua jurisdição. A construção e o embelezamento das vilas, concessão de licenças e publicação de editais para o controle das construções eram algumas das obrigações das câmaras.

De acordo com Borrego ${ }^{168}$, as rendas advindas dos termos de aforamento eram importantes para o pagamento das despesas das municipalidades e, portanto, os oficiais camarários exerciam forte controle sobre esse tributo gerando descontentamento na

\footnotetext{
${ }^{164}$ SANTIAGO, Camila Fernanda Guimarães. Vila Ricas em festas: as festas promovidas pelo Senado da Câmara de Vila Rica (1711-1744). Belo Horizonte: UFMG, 2001.

${ }^{165}$ Ibdem.

${ }^{166}$ Ibdem.

${ }^{167}$ BORREGO, Maria Aparecida de Menezes. Códigos e práticas: o processo de constituição urbana em Vila Rica colonial (1702-1748). São Paulo: Annablume, 2004.

${ }^{168}$ Ibdem.
} 
população. A resolução de cinco de março de 1712 denota a preocupação da Câmara de Vila Rica com a falta de pagamento dos termos de aforamento pelos moradores ${ }^{169}$ :

Resolveram que porquanto muitas pessoas que fabricam rancho nesta vila o fazem sem licença deste Senado não obstante o ter sido posto em edital que se lhes proíbe o levantá-los sem licença deste Senado, o aforamento dele o que é em prejuízo das rendas do conselho ordenaram que toda a pessoa que levantar rancho sem a dita licença seja condenada na postura do conselho e se lhe mande botar abaixo a sua custa e o mesmo se entenderá com os que tiverem principiado antes do dito edital não estando realmente acabados, o com todos aqueles que quiserem consertar ou reedificar alguma casa das que estão feitas, para que desta sorte se vão endireitando as ruas.

O controle do espaço pelas municipalidades nas Minas estava em consonância com a conformação territorial engendrada pela Coroa para a capitania. Conforme Borrego ${ }^{170}$ assinala, para a monarquia lusa, a construção do espaço ultramarino deveria expressar a ideia de colonização portuguesa para a região. A urbanização da capitania tinha a função de estabelecer a ordem e conter os vassalos. A função das municipalidades era de cuidar para que a conformação do espaço ocorresse de acordo com o estipulado pelo Estado português. Para a autora, frequentemente, essa forma de controle territorial causou insatisfação na população porque, muitas vezes, não condizia com as necessidades de quem habitava a zona mineradora $^{171}$.

Para Joaquim Romero Magalhães ${ }^{172}$, as municipalidades possuíam uma relação ambígua com a população das Minas. Ao mesmo tempo em que representavam os interesses dos vassalos junto a Coroa, os camarários tinham que intermediar as ordens régias na região mineradora. Um dessas determinações do Estado português era que os camarários disciplinassem os povos das Minas transformando-os em súditos obedientes e leais a monarquia lusa ${ }^{173}$. Todavia, essa dupla função não foi sempre exercida porque, frequentemente, os oficiais camarários utilizavam seus cargos em benefício próprio: ora, para

\footnotetext{
${ }^{169}$ Atas da Câmara Municipal de Ouro Preto (1711-1715). Anais da Biblioteca nacional. 1927. v. 49, p. 199-391, p. 230, TERMO de vereação que fizeram os oficiais da câmara em resolveram se não fizessem ranchos sem se aforarem.

${ }^{170}$ BORREGO, Maria Aparecida de Menezes. Códigos e práticas: o processo de constituição urbana em Vila Rica colonial (1702-1748). São Paulo: Annablume, 2004.

${ }^{171}$ Ibdem.

${ }^{172}$ MAGAlHÃES, Joaquim Romero. As Câmaras Municipais, a Coroa e a cobrança dos quintos do ouro nas Minas Gerais (1711-1750). In GONÇALVES, Andréia Lisly; CHAVES, Cláudia Maria das Graças; VENÂNCIO, Renato Pinto (Org.) Administrando Impérios: Portugal e Brasil nos Séculos XVIII e XIX. Belo Horizonte, MG: Fino Traço, 2012.

${ }^{173}$ Ibdem.
} 
induzir a população das Minas de acordo com seus interesses particulares ou de grupo, ora, para auferir ganhos dentro da estrutura político-administrativa portuguesa ${ }^{174}$.

É importante ressaltar que os vassalos que passaram pela municipalidade de Vila Rica possuíam seus próprios anseios e história, que influenciavam diretamente na condução dos negócios do Rei e nos interesses da população. Segundo Fernanda Fioravante, os oficiais camarários de Vila Rica na primeira metade dos Setecentos estavam, fundamentalmente, envolvidos com atividades ligadas à posse de terras, tais como agricultura e mineração, e possuíam grande número de escravos ${ }^{175}$. Os súditos que conseguiam acessar os cargos camarários em Vila Rica tinham grandes cabedais e estavam inseridos em uma teia social que ultrapassava os limites da capitania e influenciava na atividade camarária ${ }^{176}$.

Fioravante $^{177}$ também destaca que os camarários possuíam uma posição social de prestígio dentro da sociedade mineradora. A grande maioria dos oficiais camarários das Minas possuíam altas patentes nas tropas de auxiliares e ordenanças da região. A autora argumenta que, para Coroa, ter homens militarizados nas municipalidades da região mineradora era fundamental porque auxiliava a monarquia portuguesa a controlar um território economicamente importante e socialmente instável ${ }^{178}$. Isso sugere que as características dos camarários também serviam como estratégia de cooptação do Estado Português para atender melhor aos seus interesses.

A ação ambígua dos oficiais camarários também derivava das múltiplas responsabilidades atribuídas às municipalidades. As câmaras tinham funções administrativas, legislativas e judiciárias no âmbito local. Conforme argumenta Magalhães ${ }^{179}$, essas múltiplas obrigações, somadas à distância do Rei, conferiam amplo poder local às municipalidades do ultramar, que, exerciam essa prerrogativa, muitas vezes, conforme o cotidiano. No entanto,

\footnotetext{
${ }^{174}$ MAGALHÃES, Joaquim Romero. As Câmaras Municipais, a Coroa e a cobrança dos quintos do ouro nas Minas Gerais (1711-1750). In GONÇALVES, Andréia Lisly; CHAVES, Cláudia Maria das Graças; VENÂNCIO, Renato Pinto (Org.) Administrando Impérios: Portugal e Brasil nos Séculos XVIII e XIX. Belo Horizonte, MG: Fino Traço, 2012.

${ }^{175}$ FIORAVANTE, Fernanda "Äs custas do sangue, fazenda e escravos": formas de enriquecimento e padrão de ocupação dos ofícios da Câmara de Vila Rica, c. 1711 - c. 1736. Rio de Janeiro: UFRJ, PPGHIS, 2008.

${ }^{176}$ Ibdem.

${ }^{177}$ Ibdem.

${ }^{178}$ Ibdem.

${ }^{179}$ MAGALHÃES, op. cit.
} 
mesmo que as câmaras não cumprissem a incumbência de intermediar incondicionalmente os interesses lusos nas Minas, as municipalidades eram fundamentais para a manutenção do poder do Estado português na região porque permitiam a presença política da Coroa lusa na área mineradora ${ }^{180}$.

Segundo Maria de Fátima da Silva Gouvêa, a monarquia portuguesa também buscou formas de diminuir o poder das câmaras nas Minas. Para cercear o poder das municipalidades na região mineradora, a Coroa criou grande quantidade de câmaras na zona central de prospecção do ouro. Esse elevado número de municipalidades próximas fez com que as câmaras tivessem grande poder na sua jurisdição, porém, pouco poder de ação dentro da estrutura política e administrativa do Estado português ${ }^{181}$.

É fundamental destacar que o número de câmaras instaladas durante os Setecentos no território das Minas foi pequeno. Segundo Cláudia Damasceno Fonseca ${ }^{182}$ a capitania de Minas Gerais contou com 16 municipalidades durante o período colonial. A autora afirma que a instalação das câmaras ocorreu apenas nas áreas urbanas e de produção do ouro porque eram áreas de grande concentração populacional e importantes economicamente para a Coroa lusa. No sertão das Minas predominou a existência de arraiais.

A implantação de muitas municipalidades nas áreas que concentravam riquezas minerais também trouxe dificuldades para contestação das ordens régias pelos oficiais camarários das Minas porque existiam muitos pólos de poder no mesmo território ${ }^{183}$. Em situações de conflito de interesses com a Coroa, para as câmaras auferirem mudanças na política metropolitana, era necessário agir em conjunto e, nem sempre, isso foi possível devido aos múltiplos interesses envolvidos. Foi aproveitando essa deficiência das câmaras das Minas que o Estado português conseguiu apoio para governar e, principalmente, para

\footnotetext{
${ }^{180}$ MAGALHÃES, Joaquim Romero. As Câmaras Municipais, a Coroa e a cobrança dos quintos do ouro nas Minas Gerais (1711-1750). In GONÇALVES, Andréia Lisly; CHAVES, Cláudia Maria das Graças; VENÂNCIO, Renato Pinto (Org.) Administrando Impérios: Portugal e Brasil nos Séculos XVIII e XIX. Belo Horizonte, MG: Fino Traço, 2012.

${ }^{181}$ GOUVÊA, Maria de Fátima da Silva. Dos poderes de Vila Rica do Ouro Preto: notas preliminares sobre a organização político-administrativa na primeira metade do século XVIII. Revista Varia História, Belo Horizonte, ${ }^{\circ}$ 31, p. 120-140, Jan/Jun 2004.

${ }^{182}$ FONSECA, Cláudia Damasceno. Arraiais e vilas d'el rei: espaço e poder nas Minas setecentistas. Belo Horizonte: Editora UFMG, 2011.

${ }^{183}$ GOUVÊA, op. cit.
} 
enfrentar motins e sedições conduzidos por camarários. Um exemplo disso é a Sedição de Vila Rica de 1720.

No conflito de 1720, o governador D. Pedro Miguel de Almeida, o Conde de Assumar, sobre quem comentarei adiante, teve sua autoridade contestada principalmente pelos oficiais camarários de Vila Rica. Pascoal da Silva Guimarães, um dos líderes do motim, tinha sido juiz ordinário da Câmara Vilariquenha em 1719 e seu filho, João da Silva Guimarães, era o atual ocupante do cargo ${ }^{184}$. Os dois possuíam bastante proeminência na municipalidade de Vila Rica e dificultaram bastante a pacificação do conflito pelo Conde de Assumar. Entretanto, o governador conseguiu apoio da Câmara de Vila do Carmo e se organizou para acabar com a sedição a partir da ajuda dos oficiais camarários dessa municipalidade.

\subsection{A Sedição de Vila Rica, 1720}

O movimento de 1720 em Vila Rica foi um motim que envolveu diversos conflitos de interesses. Por um lado, o aumento dos tributos cobrados na região mineradora e à maior presença do Estado português causou descontentamento na população das Minas. Por outro lado, a revolta agregou uma série de disputas entre autoridades na capitania ${ }^{185}$. No Discurso sobre a sublevação, o governador inicia o texto falando sobre as intenções dos líderes da rebelião ${ }^{186}$ :

[...] tão perniciosas conseqüências, e tanto para temer, como a presente do ano de mil setecentos e vinte, pelo temerário e inaudito fim a que se encaminhava e dirigia, qual era alçar a obediência ao seu príncipe, usurpar ao patrimônio real esta rica porção, e introduzirem-se nela despoticamente soberanos os mesmos que ainda eram indignamente vassalos.

As Minas, durante o século XVIII, foram palco de muitas rebeliões, geralmente, provocadas pelas constantes transformações na administração da região mineradora instituídas pela Coroa lusa. Segundo João Pinto Furtado ${ }^{187}$, a população das Minas era bastante sensível

\footnotetext{
${ }^{184}$ FIORAVANTE, Fernanda "Às custas do sangue, fazenda e escravos": formas de enriquecimento e padrão de ocupação dos ofícios da Câmara de Vila Rica, c. 1711 - c. 1736. Rio de Janeiro: UFRJ, PPGHIS, 2008.

${ }^{185}$ FONSECA, Alexandre Torres. A Revolta de Felipe dos Santos. In RESENDE, Maria Efigênia Lage de; VILlALTA, Luiz Carlos (Coord.). História das Minas Gerais. As minas setecentistas. Belo Horizonte, MG: Autêntica, Companhia do Tempo, vol. 1, 2007.

${ }^{186}$ DISCURSO histórico e político sobre a sublevação que nas Minas houve no ano de 1720. Belo Horizonte: Fundação João Pinheiro, 1994, p. 59.

${ }^{187}$ FURTADO, João Pinto. "Viva o Rei, viva o povo, e morra o governador": tensão política e práticas de governo nas Minas Setecentistas. In BICALHO, Maria Fernanda Baptista; FERLINI, Vera Lúcia Amaral
} 
as mudanças na política metropolitana para região, principalmente, quando envolvia a alteração nas formas de arrecadação dos tributos.

De acordo com Furtado ${ }^{188}$, nem sempre as reações as medidas do Estado português tiveram um caráter coletivo e insurgente. As câmaras foram locais de expressão dos homens bons e, em diversos momentos, os oficiais camarários, aproveitaram esse espaço para manifestarem suas insatisfações em relação à política metropolitana de forma pacífica. Por exemplo, a mudança na forma de cobrança do ouro com a instalação das Casas de Fundição e Moeda provocou diversas manifestações das municipalidades nas Minas na primeira metade dos Setecentos ${ }^{189}$.

No ano de 1713, o governador da capitania, D. Brás Baltazar da Silveira, tentou substituir o sistema de fintas com a instalação das Casas de Fundição, sem sucesso. Segundo Virgílio Pinto Noya, as câmaras da região mineradora se reuniram em Junta e aprovaram um termo no qual concordavam em contribuir com 30 arrobas anuais e o governador aceitou ${ }^{190}$.

O termo vigorou entre 1714 e 1718, quando novamente os camarários em Junta conseguiram um novo termo que reduzia o pagamento para 25 arrobas anuais e, para compensar o valor perdido sobre a arrecadação do ouro, transferia as rendas de passagem das câmaras para a Coroa ${ }^{191}$. Entretanto, o Estado Português não ficou satisfeito e, em 1719, determinou a criação das Casas de Fundição. Essa medida foi o estopim para a Sedição de Vila Rica de $1720^{192}$.

Com a intenção de consolidar o poder da monarquia portuguesa nas Minas, em 1717 chegou à colônia um novo governador para capitania de São Paulo e Minas do Ouro ${ }^{193}$. Militar de uma família proeminente no Reino, D. Pedro Miguel de Almeida, o Conde de

(Coord.). Modos de governar: idéias e práticas políticas no Império português, séculos XVI-XIX. São Paulo: Alameda, 2005.

${ }^{188}$ Ibdem.

${ }^{189}$ Ibdem.

${ }^{190}$ PINTO, Virgilio Noya. O ouro brasileiro e o comércio anglo-português: uma contribuição aos estudos da economia atlântica no século XVIII. São Paulo: Companhia Editora Nacional, 1979.

${ }^{191}$ Ibdem.

${ }^{192}$ FONSECA, Alexandre Torres. A Revolta de Felipe dos Santos. In RESENDE, Maria Efigênia Lage de; VILLALTA, Luiz Carlos (Coord.). História das Minas Gerais. As minas setecentistas. Belo Horizonte: Autêntica, Companhia do Tempo, vol. 1, 2007.

${ }^{193}$ DISC URSO histórico e político sobre a sublevação que nas Minas houve no ano de 1720. Belo Horizonte: Fundação João Pinheiro, 1994. (Estudo crítico de Laura de Mello e Souza). 
Assumar, participou da Guerra de Sucessão Espanhola durante oito anos junto com seu pai. Como muitas famílias abastadas, os Assumar contraíram muitas dívidas com a longa permanência no exterior e a derrota de Portugal para a Espanha ${ }^{194}$.

Para Laura de Mello e Souza ${ }^{195}$, a vinda de D. Pedro Miguel de Almeida para o governo das Minas estava associada ao desejo do Conde de resolver seus problemas financeiros e auferir maior prestígio dentro da administração portuguesa. Conhecido por suas habilidades em postos de comando, o novo governador, presenciou nas Minas uma das conjunturas políticas mais adversas da América lusa. Segundo Maria Verônica Campos ${ }^{196}$, o governo do Conde enfrentou 16 das 46 revoltas ocorridas na região mineradora entre 1694 e 1736.

No dia onze de janeiro de 1719, buscando evitar os descaminhos dos minerais, D. João V enviou uma carta a D. Pedro Miguel de Almeida, determinando ao governador construir as Casas de Fundição para iniciar a cobrança do ouro pelo quinto. Dois meses depois, o Rei solicitou que o governador escolhesse os locais mais adequados para a instalação das Casas. Em 16 de junho de 1719, ficou acordado em Junta que as Casas de Fundição seriam edificadas nas seguintes cabeças de comarca: Vila Rica, Sabará, Vila do Príncipe e São João del-Rei. Além disso, ficou estipulada a criação de registros em Borda do Campo, Rio Grande e Rio das Velhas. Essas medidas deveriam ser implantadas no prazo de um ano ${ }^{197}$.

No dia 28 de junho de 1720, com a iminência da nova cobrança, o povo de Vila Rica ficou inquieto e amotinou-se. Nas comemorações de São Pedro, mascarados armados desceram a noite o Morro do Ouro Podre, de propriedade de Pascoal da Silva Guimarães, e, com o apoio da população, foram em direção à casa do ouvidor-geral da comarca de Ouro Preto, Martinho Vieira, para destituí-lo do cargo. Entretanto, o governador, sabendo do clima de tensão que rondava em Vila Rica nas vésperas do novo imposto, pediu que Vieira fosse

\footnotetext{
${ }^{194}$ DISCURSO histórico e político sobre a sublevação que nas Minas houve no ano de 1720. Belo Horizonte: Fundação João Pinheiro, 1994. (Estudo crítico de Laura de Mello e Souza).

${ }^{195}$ Ibdem.

${ }^{196}$ Cf. CAMPOS, Maria Verônica. Governo de mineiros: “de como meter as Minas numa moenda e beberlhe o caldo dourado 1693 a 1737. São Paulo: USP, FFLCH, 2002. p. 390-398.

${ }^{197}$ CÓDICE Costa Matoso. Belo Horizonte: Fundação João Pinheiro, vol. 2, 1999, Coordenação-geral de Luciano Raposo de Almeida Figueiredo e Maria Verônica Campos.
} 
para Vila do Carmo para arrefecer os ânimos. Ao não encontrá-lo, os amotinados invadiram e depredaram a casa do ouvidor ${ }^{198}$. No Discurso Assumar relata ${ }^{199}$ :

[...] escreveu a Câmara ao Conde que o povo não sossegava com a assistência do ouvidor naquela Vila e com termos petulantes instavam que se retirasse, e com efeito houve receios que ali mesmo o matassem, porque se viram algumas noites vários rebuçados andar à roda de sua casa. Com esta notícia, lhe mandou dizer o Conde que se retirasse para fora da comarca até ver o estado em que se punham as coisas; pois, conhecido o ânimo dos cabeças, não era bom sustentar ali este torcedor para os seus desígnios.

Os escritos coevos mencionam que Martinho Vieira, devido ao seu comportamento inapropriado, colecionava desafetos na região mineradora. No Discurso, podemos observar que o próprio D. Pedro Miguel de Almeida tinha suas objeções sobre o ouvidor-geral ${ }^{200}$ :

Requereram pois que fosse o ouvidor Martinho Vieira fora do seu lugar. E nenhuma coisa na verdade pediram com tanta razão, porque a imprudência do dito ouvidor a ninguém mais que ao Conde fazia recear que se voltasse outra vez para o seu lugar, desse logo motivo para novo incêndio, e sem dúvida, que naquele tempo a sua leviandade abriria de um jato a porta que a prudência do Conde tantas vezes fechara às ruínas.

O episódio na casa de Martinho Vieira também estava atrelado ao conflito entre autoridades que se desenrolou durante a sedição. De acordo com João Henrique Ferreira de Castro $^{201}$, em 1718, Manoel Mosqueira da Rosa, um dos líderes da rebelião de 1720, tinha sido intensamente criticado pelo Conde porque atrasou bastante o processo de devassa de Catas Altas e foi muito violento com os revoltosos ${ }^{202}$ :

Seja porque tem acabado o seu tempo e se teme da residência, ou por costumado a fazer a Justiça as avessas, intimidou desta sorte as testemunhas, que sendo infinitas as desordens de que se me queixaram, ficaram os negros e feitores de Manoel Rodrigues Soares por elas pouco menos que santos.

\footnotetext{
${ }^{198}$ CÓDICE Costa Matoso. Belo Horizonte: Fundação João Pinheiro, vol. 2, 1999, Coordenação-geral de Luciano Raposo de Almeida Figueiredo e Maria Verônica Campos.

${ }^{199}$ DISCURSO histórico e político sobre a sublevação que nas Minas houve no ano de 1720. Belo Horizonte: Fundação João Pinheiro, 1994. (Estudo crítico de Laura de Mello e Souza), p. 113-114.

${ }^{200}$ Ibdem.

${ }^{201}$ CASTRO, João Henrique Ferreira de. O Conde de Assumar e a repressão às revoltas ocorridas nas Minas muito além da sedição de Vila Rica de 1720: Perdões e concessões como instrumentos de manutenção da ordem. CHAMBOULEYRON, Rafael e ARENZ, Karl-Heinz (orgs.). Anais do IV Encontro Internacional de História Colonial - Conflitos, revoltas e insurReições na América Portuguesa. Belém: Editora Açaí, 2014 , v. 12 , p. $60-72$.

${ }^{202}$ Para o Tenente General Manuel da Costa Fragoso, 05/11/1718. APM - SC-11. Cartas, ordens, despachos, bandos ou editais do Governador das Minas Gerais, p. 69. Apud. Ibdem, p. 66.
} 
A partir de então se originou um conflito entre Mosqueira e Assumar que só foi resolvido após o governador sufocar a Sedição de Vila Rica em $1720^{203}$.

Depois das manifestações na casa do ouvidor-geral, os rebelados encaminharam-se para frente da Câmara de Vila Rica. Lá os amotinados leram um Termo que continha quinze condições para por fim ao motim ${ }^{204}$. Pelo documento, os revoltosos eram contra os novos contratos, a implantação das Casas de Fundição e do novo registro em Borda do Campo. Eram a favor da manutenção da circulação do ouro em pó e do controle no processo de aferição; e, reclamavam do pagamento do aboletamento das companhias de Dragões e dos abusos de poder perpetrados, principalmente, pelos camarários de Vila Rica ${ }^{205}$.

As reivindicações expressadas no Termo revelam que a grande quantidade de impostos e taxas cobrados na região mineradora era $\mathrm{o}$ fator que mais causava descontentamento na população ${ }^{206}$. A tradição de contestação do povo das Minas somada à tentativa de maior controle da fiscalidade acalorou os ânimos na região mineradora a tal ponto que provocou uma das conjunturas mais insurgentes da América portuguesa no início do século XVIII ${ }^{207}$.

D. Pedro Miguel de Almeida não acatou as reivindicações expostas no Termo e a população continuou as assuadas por Vila Rica. Para conter a sedição, o governador tentou reunir os Dragões, porém, não conseguiu porque [...] estavam fora da Vila dispersos por casa dos paisanos, por não estarem ainda concluídos os quartéis; o que não se conseguiu antes de vinte e quatro horas, por serem grandes as distâncias $[\ldots]^{208}$.

\footnotetext{
${ }^{203}$ CÓDICE Costa Matoso. Belo Horizonte: Fundação João Pinheiro, vol. 2, 1999, Coordenação-geral de Luciano Raposo de Almeida Figueiredo e Maria Verônica Campos.

${ }^{204}$ TERMO que se fez sobre a proposta do povo de Vila Rica na ocasião em que veio amotinado a Vila do Carmo. In ANASTASIA, Carla Maria Junho. Vassalos Rebeldes: violência coletiva nas Minas na primeira metade do século XVIII. Belo Horizonte: C/Arte, 1998, p. 141-143.

${ }^{205}$ Ibdem.

${ }^{206}$ FONSECA, Alexandre Torres. A Revolta de Felipe dos Santos. In RESENDE, Maria Efigênia Lage de; VILLALTA, Luiz Carlos (Coord.). História das Minas Gerais. As minas setecentistas. Belo Horizonte, MG: Autêntica, Companhia do Tempo, vol. 1, 2007.

${ }^{207}$ FIGUEIREDO, Luciano. Tradições Radicais: aspectos da cultura política mineira setecentista. In RESENDE, Maria Efigênia Lage de; VILLALTA, Luiz Carlos (Coord.). História das Minas Gerais. As minas setecentistas. Belo Horizonte: Autêntica, Companhia do Tempo, vol. 1, 2007.

${ }^{208}$ DISCURSO histórico e político sobre a sublevação que nas Minas houve no ano de 1720. Belo Horizonte: Fundação João Pinheiro, 1994. (Estudo crítico de Laura de Mello e Souza), p. 96.
} 
É importante ressaltar que o problema com a falta de tropas para repressão de conflitos era recorrente nas Minas. Segundo João Henrique Ferreira de Castro, desde o fim do Levante dos Emboabas, vários oficiais régios já vinham alertando a monarquia portuguesa sobre a necessidade de estabelecer um regimento pago na região mineradora para facilitar na contenção de rebeliões ${ }^{209}$.

Em 1719, o Rei autorizou o estabelecimento de dois regimentos de dragões nas Minas e a construção de um quartel para abrigar as novas tropas. Essas medidas causaram grande alvoroço na área mineradora. Os custos do estabelecimento dos terços de dragões nas Minas recairiam sobre a população e, principalmente, sobre as câmaras ${ }^{210}$. Também, a presença das tropas pagas ameaçava o poder dos potentados locais.

Os homens bons das Minas ocupavam cargos altos na estrutura militar da região. A maioria desses vassalos auferiu suas patentes devido aos serviços prestados a Coroa desde o início da mineração. Por exemplo, em 1710, os franceses invadiram o litoral fluminense e os súditos das Minas foram chamados pelo governador do Rio de Janeiro, Francisco de Castro Morais, para auxiliar na defesa da região. Entretanto, quando chegaram ao local, os franceses já tinham sido expulsos. De acordo com Carlos Leonardo Kelmer Mathias ${ }^{211}$, posteriormente, vários homens que acudiram na diligência pleitearam, junto ao Estado português, novas mercês com a justificativa de que tinham servido a Coroa contra os franceses às custas de sua vida, fazenda e negros armados. Na carta patente de Silvestre Marques da Cunha, o governador das Minas, D. Brás Baltasar, destaca a participação do vassalo na diligência de 1710 no Rio de Janeiro ${ }^{212}$ :

[...] respeito aos merecimentos e mais partes que concorrem na pessoa de Silvestre Marques da Cunha, e a boa satisfação com que se houve em todo o tempo que militou assim no Reino como na praça do Rio de Janeiro e ao bem que precedeu com que ocupou o posto de sargentomor da cavalaria da Vila de São João del-Rei.

\footnotetext{
${ }^{209}$ CASTRO, João Henrique Ferreira de. O Conde de Assumar e a repressão às revoltas ocorridas nas Minas muito além da sedição de Vila Rica de 1720: Perdões e concessões como instrumentos de manutenção da ordem. CHAMBOULEYRON, Rafael e ARENZ, Karl-Heinz (orgs.). Anais do IV Encontro Internacional de História Colonial - Conflitos, revoltas e insurReições na América Portuguesa. Belém: Editora Açaí, 2014, v. 12 , p. $60-72$.

${ }^{210}$ Ibdem.

${ }^{211}$ MATHIAS, Carlos Leonardo Kelmer. Jogos de interesses e redes clientelares na revolta mineira de Vila Rica (c. 1709 - c. 1736). Rio de Janeiro: UFRJ, PPGHIS, 2005.

${ }^{212}$ APM, SC 12, fls. 21-21v. PROVISÃO passada a Silvestre Marques da Cunha, 24/11/1717.
} 
Com a introdução das tropas pagas nas Minas, além de perderem o domínio militar da região, os homens bons teriam que dividir os louros da defesa do território com os novos regimentos, diminuindo seu prestígio junto ao Estado português e dificultando a obtenção de novas mercês ${ }^{213}$.

Diante da falta de homens para reprimir a rebelião, Assumar escreveu uma carta a Câmara de Vila Rica dizendo que se a ordem fosse restabelecida, atenderia às reivindicações dos amotinados e concederia o perdão aos revoltosos. O governador malogrou e, sem forças, recuou momentaneamente ${ }^{214}$.

Os líderes do motim continuaram a insuflar a população contra D. Pedro Miguel de Almeida, mesmo após o governador aceitar as condições do Termo para por fim a rebelião, porque esse resultado não contemplava seus anseios. Pascoal da Silva Guimarães, Manoel Mosqueira da Rosa, Sebastião da Veiga Cabral, frei Vicente Botelho, frei Francisco de Monte Alverne e frade Bento tinham outras intenções que ultrapassavam as reivindicações da população $^{215}$.

O já citado Manoel Mosqueira da Rosa, via na Sedição de Vila Rica de 1720 uma oportunidade de expulsar o governador das Minas e retornar ao cargo de ouvidor-geral da comarca de Ouro Preto. O sargento-mor Sebastião da Veiga Cabral tinha desavenças com o governador e almejava, com o fim do conflito, ocupar o cargo de D. Pedro Miguel de Almeida. Os religiosos participaram da rebelião por terem ligações com os outros líderes. Já Pascoal da Silva Guimarães, mesmo possuindo enorme prestígio junto à Coroa e sendo um dos comerciantes mais proeminentes da capitania, participou da sedição porque devia muito na praça e poderia ser prejudicado pelas mudanças na arrecadação dos impostos ${ }^{216}$.

\footnotetext{
${ }^{213}$ CÓDICE Costa Matoso. Belo Horizonte: Fundação João Pinheiro, vol. 2, 1999, Coordenação-geral de Luciano Raposo de Almeida Figueiredo e Maria Verônica Campos.

${ }^{214}$ Ibdem.

${ }^{215}$ FONSECA, Alexandre Torres. A Revolta de Felipe dos Santos. In RESENDE, Maria Efigênia Lage de; VILLALTA, Luiz Carlos (Coord.). História das Minas Gerais. As minas setecentistas. Belo Horizonte, MG: Autêntica, Companhia do Tempo, vol. 1, 2007.

${ }^{216}$ FIORAVANTE, Fernanda "Äs custas do sangue, fazenda e escravos": formas de enriquecimento e padrão de ocupação dos ofícios da Câmara de Vila Rica, c. 1711 - c. 1736. Rio de Janeiro: UFRJ, PPGHIS, 2008.
} 
Sugere Fernanda Fioravante $^{217}$ que Guimarães temia, com o maior controle na fiscalidade nas Minas, que os credores quisessem reaver o dinheiro para arcar com as novas formas de cobrança de tributos. Também, era conveniente para Pascoal o retorno da Mosqueira para o cargo de ouvidor da comarca porque, caso não conseguisse quitar as dívidas, o comerciante poderia ser citado pelo ouvidor Martinho Vieira, de quem não era aliado $^{218}$.

Alguns dias depois, com o apoio da tropa dos dragões e do máximo de homens armados que conseguiu arregimentar nas Minas, o Conde ordenou o fechamento das entradas da região mineradora e a prisão dos principais líderes da revolta, inclusive de Pascoal da Silva Guimarães. Como conseqüencia desse "atrevimento" do conde, João da Silva, filho de Pascoal, preparou uma grande agitação em Vila Rica. Com ajuda de Felipe dos Santos e "grosso número de negros armados",219. Assumar ameaçou punir severamente Pascoal caso os tumultos não cessassem. Guimarães mandou uma carta ao filho pedindo para acabar com as perturbações em Vila Rica ${ }^{220}$.

A Sedição terminou. D. Pedro Miguel de Almeida, para disciplinar os povos das Minas, resolveu aplicar um castigo exemplar: mandou atear fogo nas casas do Morro do Ouro Podre, propriedade de Pascoal da Silva Guimarães, e ordenou a execução de Felipe dos Santos $^{221}$. Contudo, Assumar ainda continuou sofrendo ameaças após o término da rebelião porque os líderes do movimento, mesmo presos no Rio de Janeiro, insuflaram intrigas nas Minas contra o governador até meados de 1721, quando foram remetidos para Lisboa ${ }^{222}$.

É imprescindível tecer algumas considerações sobre as punições aplicadas por D. Pedro Miguel de Almeida aos sediciosos de Vila Rica em 1720. A historiografia que trata sobre os motins ocorridos na região mineradora no início dos Setecentos sempre destacou que

\footnotetext{
${ }^{217}$ FIORAVANTE, Fernanda "Às custas do sangue, fazenda e escravos": formas de enriquecimento e padrão de ocupação dos ofícios da Câmara de Vila Rica, c. 1711 - c. 1736. Rio de Janeiro: UFRJ, PPGHIS, 2008.

${ }^{218}$ Ibdem.

${ }^{219}$ DISCURSO histórico e político sobre a sublevação que nas Minas houve no ano de 1720. Belo Horizonte: Fundação João Pinheiro, 1994, (Estudo crítico de Laura de Mello e Souza), p. 131.

${ }^{220}$ FONSECA, Alexandre Torres. A Revolta de Felipe dos Santos. In RESENDE, Maria Efigênia Lage de; VILlALTA, Luiz Carlos (Coord.). História das Minas Gerais. As minas setecentistas. Belo Horizonte: Autêntica, Companhia do Tempo, vol. 1, 2007.

${ }^{221}$ BANDO de 13 de julho de 1720. APM, SC, Códice SG 11, fls. 291-291v.

${ }^{222}$ DISCURSO, op. cit., p. 131.
} 
os castigos recebidos pelos revoltosos de 1720 eram fruto da personalidade intempestiva de Assumar. Entretanto, estudos mais recentes, como os de Marcos Aurélio de Paula Pereira ${ }^{223}$ e João Henrique Ferreira de Castro ${ }^{224}$, sugerem que a conduta do Conde no governo das Minas foi influenciada pela lenta transformação na concepção política de Razão de Estado no Império Português, encetada no início do século XVIII.

Segundo Pedro Calafate ${ }^{225}$, apesar dos textos filosóficos portugueses dos Seiscentos estarem inseridos em um enquadramento escolástico, esses escritos tinham uma lógica mais racional do Estado e do poder do soberano. Essa novo concepção política inverteu a lógica de governo. O poder do governante passou a ser delegado pelo povo. Ao invés de ser um direito do Rei passou a ser um dever dos monarcas com os governados. Logo o governante deveria gerir o Estado para promover o bem comum entre os povos ${ }^{226}$.

As novas idéias que circulavam no Reino contribuíram para desencadear um processo longo de racionalização das estruturas administrativas e burocráticas do Império luso ${ }^{227}$. Tal mudança afetou lentamente a mentalidade dos oficiais régios, que vieram para o governo do ultramar no século XVIII. Assumar sofreu as influências desta nova concepção de Estado português e seu governo nas Minas foi marcado por uma maior rigidez na condução dos interesses da Coroa na região, provocando uma série de manifestações negativas na população $^{228}$. Segundo Castro ${ }^{229}$, os castigos aplicados na Sedição de Vila Rica em 1720 estavam em consonância com esta nova concepção política do Império português ${ }^{230}$.

Mesmo influenciado pela nova concepção de Razão de Estado lusa, o Conde conservou algumas características comuns aos outros oficiais régios que passaram pela governança da área mineradora. D. Pedro Miguel de Almeida utilizou a cooptação social para

\footnotetext{
${ }^{223}$ PEREIRA, Marcos Aurélio de Paula. Vivendo Entre Cafres: Vida e Política do Conde de Assumar no Ultramar, 1688-1756. Niterói: UFF, ICHF, 2009.

${ }^{224}$ CASTRO, João Henrique Ferreira de. A repressão à Revolta de Vila Rica de 1720: Perdão e Punição sob a ótica da justiça no Império Ultramarino Português. Rio de Janeiro: UFRJ, PPGHIS, 2012.

${ }^{225}$ CALAFATE, Pedro. A Reflexão portuguesa sobre a política nos séculos XVI e XVII. In CALAFATE, Pedro (dir.). História do pensamento filosófico português. Vol. 2. Lisboa: Caminho, 1999, p. 663-700.

${ }^{226}$ Ibdem.

${ }^{227}$ PEREIRA, op. cit.

${ }^{228}$ CASTRO, op. cit.

${ }^{229}$ Ibdem.

${ }^{230}$ Ibdem.
} 
angariar apoio entre os homens bons das Minas, através da concessão de mercês e benesses ${ }^{231}$. Por exemplo, em 1718, no motim de Catas Altas, o governador não possuía forças para enfrentar Manuel Rodrigues Soares, comerciante poderoso da região. Para neutralizar as ações de Soares e conquistar apoio nas Minas, o governador pediu ao Rei a confirmação do hábito da ordem de Cristo solicitado anteriormente pelo comerciante. Ao invés de punir Soares, o governador optou por terminar o conflito de forma pacífica e também por aumentar sua teia de relações na região, fazendo um novo aliado ${ }^{232}$.

Para João Henrique Ferreira de Castro ${ }^{233}$, as atuações do Conde na repressão de motins denotam sua predisposição para resolver conflitos através da negociação e aumentar, cada vez mais, sua rede de relações nas Minas. No entanto, a Sedição de Vila Rica de 1720, significou uma ameaça concreta à presença de oficiais régios na área mineradora, forçando D. Pedro Miguel de Almeida a mudar sua postura.

Os líderes da Sedição almejavam expulsar os oficiais nomeados pela Coroa das Minas. Esse desejo dos revoltosos representava uma séria ameaça aos interesses régios na região mineradora. Assumar, imbuído da nova concepção de Razão de Estado, optou por garantir a prevalência dos interesses da monarquia portuguesa, aplicando uma punição exemplar a Felipe dos Santos e castigando os líderes do motim de forma que tivessem dificuldades para retornar ao seu antigo status dentro das Minas.

Outro ponto a se considerar na conduta da D. Pedro Miguel de Almeida é a punição dada a Felipe dos Santos. Assumar não poderia castigar Santos com o esquartejamento porque, até 1730, apenas o Tribunal da Relação da Bahia tinha jurisdição na América portuguesa para aplicar a pena de morte natural cruel ${ }^{234}$. O governador na carta enviada a D. João V, em 21 de julho de 1720, reconhece sua falta de poder para ordenar a execução de Felipe dos Santos: Eu, senhor, bem sei que não tinha jurisdição para proceder tão

\footnotetext{
${ }^{231}$ MATHIAS, Carlos Leonardo Kelmer. Jogos de interesses e redes clientelares na revolta mineira de Vila Rica (c. 1709 - c. 1736). Rio de Janeiro: UFRJ, PPGHIS, 2005.

${ }^{232}$ CASTRO, João Henrique Ferreira de. O Conde de Assumar e a repressão às revoltas ocorridas nas Minas muito além da sedição de Vila Rica de 1720: Perdões e concessões como instrumentos de manutenção da ordem. CHAMBOULEYRON, Rafael e ARENZ, Karl-Heinz (orgs.). Anais do IV Encontro Internacional de História Colonial - Conflitos, revoltas e insurreições na América Portuguesa. Belém: Editora Açaí, 2014, v. 12 , p. $60-72$.

${ }^{233}$ Ibdem.

${ }^{234}$ ROMEIRO, Adriana; BOTELHO, Angela Vianna. Dicionário histórico das Minas Gerais: período colonial. $2^{\mathrm{a}}$ edição revista. Belo Horizonte, MG: Autêntica, 2004, p. 201.
} 
sumariamente e que não podia fazer sem convocar os ministros da comarca; mas uma coisa é experimentá-lo e a outra ouvi-lo, porque o aperto era tão grande que não havia instante que perder. ${ }^{235}$ Apesar de Assumar argumentar na carta que a sentença de morte poderia ser proferida por decisão da Junta Geral das comarcas da região, o direito de condenar um réu a morte só foi concedido as Juntas em 21 de fevereiro de $1731 .^{236}$

Laura de Mello e Souza ${ }^{237}$ atribui ao castigo dado a Felipe dos Santos uma das principais motivações para a escrita do Discurso pelo Conde. Apesar da autoria do Discurso não ser revelada no escrito, a historiografia recente considera Assumar o autor do texto com base no conteúdo e a forma rebuscada de escrita utilizada no documento ${ }^{238}$. Para Souza, durante a leitura do Discurso é perceptível a intenção de defender a postura de D. Pedro Miguel de Almeida em relação a Felipe dos $\operatorname{Santos}^{239}$ :

\begin{abstract}
À vista da sua confissão, e de ser apanhado em flagrante, foi no mesmo dia, com aplauso dos moradores, enforcado e esquartejado, os quais, conhecida a maldade, se bem a princípio favoreceram os seus desígnios, agora, mudando de parecer, tudo era detestar os conselhos e maldizer as indústrias de Filipe dos Santos e dos mais cabeças e aplaudir ao Conde, com o gosto de se verem livres da opressão. Dispondo Deus (que nos castigas tem alguma conformidade com os pecados) que até na morte não tivesse em si união e lhe faltasse o descanso da sepultura, cadáver que em vida pertubava nos mais a paz e destruía o sossego.
\end{abstract}

Todavia, a sentença de morte dada a Felipe dos Santos não foi considerada anormal para os padrões do Antigo Regime. O castigo exemplar era uma prática aceita no Império português e era prevista no livro V das Ordenações Filipinas ${ }^{240}$. Segundo João Pinto Furtado, era costume no Antigo Regime aplicar punições exemplares para lembrar a população do que acontecia com os vassalos que desafiavam o poder régio ${ }^{241}$. No Discurso, uma das

\footnotetext{
${ }^{235}$ COLEÇÃO sumária das próprias leis, cartas régias, avisos e ordens que se acham nos livros da Secretaria do Governo desta capitania de Minas Gerais. Revista do Arquivo Público Mineiro. Belo Horizonte, MG: Imprensa Oficial das Minas Gerais, Ano XVI, 1911, vol. 1.

${ }^{236}$ Ibdem.

${ }^{237}$ DISCURSO histórico e político sobre a sublevação que nas Minas houve no ano de 1720. Belo Horizonte: Fundação João Pinheiro, 1994, (Estudo crítico de Laura de Mello e Souza).

${ }^{238}$ PEREIRA, Marcos Aurélio de Paula. Vivendo Entre Cafres: Vida e Política do Conde de Assumar no Ultramar, 1688-1756. Niterói: UFF, ICHF, 2009.

${ }^{239}$ DISCURSO, op. cit., p. 137.

${ }^{240}$ ROMEIRO, Adriana; BOTELHO, Angela Vianna. Dicionário histórico das Minas Gerais: período colonial. $2^{\mathrm{a}}$ edição revista. Belo Horizonte, MG: Autêntica, 2004, p. 200.

${ }^{241}$ FURTADO, João Pinto. O manto de Penélope: história, mito e memória da Incofidência Mineira de 1788-1799. São Paulo: Companhia das Letras, 2002.
} 
justificativas dadas à execução de Felipe dos Santos era que o castigo serviria para disciplinar a população das Minas pelo exemplo ${ }^{242}$ :

\begin{abstract}
Quanto mais que, ainda deposto o exemplo que daqui se esperava, e com efeito se conseguiu, sempre se devia proceder com algum rigor contra a maldade de Filipe dos Santos, porque justo era que onde a maldade crescia tanto, algum rigor se acrescentasse às leis [...] Este exemplo, que em outra parte escassamente fora ameaço a sombra de justiça, nas Minas, onde as sedições eram naturais e o castigo estranho, pareceu excesso de rigor e resolução muito sumária. E o mesmo cuido que quisera entender na Bahia e Rio de Janeiro muitos, que falam de longe, por não dizer que de cor, e que não presenciaram o caso nem sabem que casta de gente são os mineiros. Não me admiro eu tanto da insolência dos cabeças e seus aderentes quanto da paciência do Conde: não tanto que não cessassem em tantos dias os atrevimentos quanto que, na mesma hora não brotassem logo os castigos.
\end{abstract}

Apesar de D. Pedro Miguel de Almeida ter conseguido reprimir a Sedição de Vila Rica em 1720, o governador sofreu uma série de conseqüências negativas após a rebelião. Além de ter que lidar com as intrigas provocadas pelos presos do movimento até 1721, Assumar quando retornou para o Reino sofreu um processo devido à queima das casas de Pascoal da Silva Guimarães no Morro do Ouro Podre ${ }^{243}$.

Segundo Laura de Mello e Souza ${ }^{244}$, o processo de Guimarães impediu que o Conde prestasse contas do seu governo nas Minas, colocando em dúvida a idoneidade de D. Pedro Miguel de Almeida ${ }^{245}$. A autora afirma que essa situação deixou D. Pedro Miguel de Almeida marginalizado na Corte por longos anos ${ }^{246}$. Todavia, tempos depois, o Conde de Assumar conseguiu se recuperar e foi agraciado com o governo das Índias ${ }^{247}$.

Também o Conde de Assumar conseguiu implantar parcialmente as mudanças previstas para 1720. Por exemplo, as Casas de Fundição só foram instaladas em 1725, no governo de D. Lourenço de Almeida ${ }^{248}$. Contudo, D. Pedro Miguel de Almeida conseguiu estabelecer efetivamente o poder da Coroa portuguesa na área mineradora ao expulsar uma

\footnotetext{
${ }^{242}$ DISCURSO histórico e político sobre a sublevação que nas Minas houve no ano de 1720. Belo Horizonte: Fundação João Pinheiro, 1994, (Estudo crítico de Laura de Mello e Souza).

${ }^{243}$ Ibdem.

${ }^{244}$ Ibdem.

${ }^{245}$ Ibdem.

${ }^{246}$ Ibdem.

${ }^{247}$ PEREIRA, Marcos Aurélio de Paula. Vivendo Entre Cafres: Vida e Política do Conde de Assumar no Ultramar, 1688-1756. Niterói: UFF, ICHF, 2009.

${ }^{248}$ FIORAVANTE, Fernanda "Às custas do sangue, fazenda e escravos": formas de enriquecimento e padrão de ocupação dos ofícios da Câmara de Vila Rica, c. 1711 - c. 1736. Rio de Janeiro: UFRJ, PPGHIS, 2008.
} 
rede de clientela que se estabelecera na região após o Levante dos Emboabas e que obstruía muitos interesses da Coroa nas Minas ${ }^{249}$.

2.3. O governo de D. Lourenço de Almeida e a pacificação das Minas

Com o fim do governo de D. Pedro Miguel de Almeida, em 1721, um novo governador foi nomeado para a recém criada capitania das Minas Gerais. D. Lourenço de Almeida tinha governado Pernambuco (1715-1718) e possuía bastante experiência no governo do ultramar. Apesar de D. Lourenço de Almeida ter saído do governo da região mineradora devido ao seu envolvimento na extração ilegal de diamantes, a passagem do governador pelas Minas foi considerada muito profícua pela monarquia portuguesa. Não aconteceram rebeliões de grandes proporções e foram implantadas as novas formas de arrecadação do ouro ${ }^{250}$. Entre 1721 a 1735, as Minas viveram um período de relativa calmaria e prosperidade que só foi interrompida pelos motins do Vale do São Francisco em $1736^{251}$.

Em parte, a estabilidade do governo de D. Lourenço de Almeida deveu-se à nova configuração da Câmara de Vila Rica. Conforme assinalei anteriormente, uma das conquistas de Assumar durante o seu governo foi o desmantelamento de uma rede clientelar, formada pelos homens bons que chegaram as Minas em busca do ouro no início do século XVIII e ascenderam aos cargos da administração da região mineradora após o Levante dos Emboabas. Depois da contenção da Sedição de 1720, os homens bons que assumiram a municipalidade Vilariquenha eram ligados a Assumar e tinham contribuído para a pacificação do movimento $^{252}$. Mesmo a nova Câmara de Vila Rica sendo mais propensa a acatar as ordens régias, durante o governo de $\mathrm{D}$. Lourenço de Almeida ocorreram muitas tensões entre a municipalidade e o governador.

Durante a segunda década dos Setecentos, as câmaras das Minas tiveram progressivamente suas rendas diminuídas e suas obrigações aumentadas pelos governadores

\footnotetext{
${ }^{249}$ KELMER MATHIAS, Carlos Leonardo. Jogos de interesses e redes clientelares na revolta mineira de Vila Rica (c. 1709 - c. 1736). Rio de Janeiro: UFRJ, PPGHIS, 2005.

${ }^{250}$ ROMEIRO, Adriana; BOTELHO, Angela Vianna. Dicionário histórico das Minas Gerais: período colonial. $2^{\mathrm{a}}$ edição revista. Belo Horizonte, MG: Autêntica, 2004.

${ }^{251}$ Ibdem.

${ }^{252}$ FIORAVANTE, Fernanda "Às custas do sangue, fazenda e escravos": formas de enriquecimento e padrão de ocupação dos ofícios da Câmara de Vila Rica, c. 1711 - c. 1736. Rio de Janeiro: UFRJ, PPGHIS, 2008.
} 
que passaram pela região. Segundo Fernanda Fioravante, a questão dos tributos, do aboletamento das tropas de Dragões e da construção de cadeias foram os temas que mais geraram reações na Câmara de Vila Rica no governo de D. Lourenço de Almeida ${ }^{253}$.

Conforme assinalei anteriormente, em 1718 os oficiais camarários das Minas firmaram um Termo em Junta que transferia as rendas de passagem para a Coroa como forma de compensar o Estado luso pela diminuição da renda do quinto. No mesmo ano, Assumar retirou das câmaras a prerrogativa de cobrar os quintos na região mineradora ${ }^{254}$. Essas medidas diminuíram drasticamente as rendas das municipalidades das Minas. No entanto, a construção das Casas de Fundição, em 1724, significou um acréscimo nas despesas das câmaras da região mineradora porque os salários dos oficiais designados para a administração das casas ficou a cargo das municipalidades ${ }^{255}$.

Quanto à questão dos dragões, em 1719, a Coroa determinou que a Câmara de Vila Rica ficasse responsável pelos custos da implantação das tropas de dragões nas Minas e o pagamento de seus salários, onerando pesadamente essa municipalidade. Em representação de 1721, a Câmara de Vila Rica reclamou ao Rei: [...] que dos bens do conselho se pagassem os aluguéis das casas em que se acham aquartelados os oficiais e soldados Dragões desde o primeiro ano que para estas Minas vieram até o tempo presente e ainda continuando as mesmas despesas ${ }^{256}$.

Em 1729, D. Lourenço de Almeida determinou que a municipalidade de Vila Rica construi-se quartéis para o aboletamento das tropas pagas já que os custos dos aluguéis eram altos e os dragões precisavam de um espaço definitivo. A partir de então, a Câmara Vilariquenha, além de arcar com os custos de aluguéis, passou a pagar também pela construção dos quartéis ${ }^{257}$. O impacto dessas medidas foi duramente sentido pela

\footnotetext{
${ }^{253}$ FIORAVANTE, Fernanda "Às custas do sangue, fazenda e escravos": formas de enriquecimento e padrão de ocupação dos ofícios da Câmara de Vila Rica, c. 1711 - c. 1736. Rio de Janeiro: UFRJ, PPGHIS, 2008.

${ }^{254}$ Ibdem.

${ }^{255}$ Ibdem.

${ }^{256}$ AHU, Cons. Ultra. - Brasil/ MG, cx. 03, doc. 64. REPRESENTAÇÃO dos oficiais da Câmara de Vila Rica sobre o pagamento dos aluguéis das casas em que se acha o quartel dos oficiais e soldados dos Dragões e pedindo ordem para resolver o problema. 21/10/1722.

${ }^{257}$ FIORAVANTE, op. cit.
} 
municipalidade de Vila Rica, provocando reação da câmara ${ }^{258}$. Em 1730, D. Lourenço de Almeida escreveu ao Rei reclamando do atraso das obras dos quartéis pelos camarários ${ }^{259}$ :

quiseram duvidar em não continuarem com esta obra, fundadas em que não tinham ordem de vossa Majestade e talvez para aplicarem o ouro a obra mais conveniente para eles, que é o que se observa nestas câmaras, por cuja causa se acham todas com grandes empenhos, tendo umas rendas muito consideráveis, e fazendo poucas obras.

A construção das cadeias na região mineradora na década de 1720 também sobrecarregou financeiramente as municipalidades. Em carta de 31 de janeiro de 1721, o monarca ordenou a construção de carceragem em todas as vilas das Minas ${ }^{260}$. O custo da obra ficou a cargo das câmaras. Para manutenção das cadeias as câmaras deveriam fazer contratos e as rendas da carceragem ficariam com as municipalidades ${ }^{261}$.

As cadeias das Minas foram construídas com uma estrutura frágil de barro e pau-apique, comum na colônia, provocando a fuga sem dificuldade dos presos. Além disso, as rendas do contrato de carceragem eram baixas e, muitas vezes, os presos entravam em conluio com os carcereiros e conseguiam fugir com bastante facilidade. Com o objetivo de coibir essas fugas, a ordem régia de 12 de setembro 1727 determinou que os contratos de carceragem nas Minas não fossem mais arrematados. Os custos de manutenção da cadeia e dos prisioneiros ficariam a cargo das municipalidades. Em 15 de fevereiro de 1730, o Rei enviou nova carta ordenando que a Câmara de Vila Rica construísse uma nova cadeia a base de pedra e cal, porém os oficiais camarários não aceitaram a medida e a construção só foi executada na segunda metade dos Setecentos ${ }^{262}$.

Em 1732, André de Melo e Castro, o quarto Conde de Galveias, assumiu o governo da capitania de Minas. O novo governador não possuía experiência no ultramar, mas tinha uma longa carreira dentro da administração eclesiástica porque serviu ao sacerdócio até 1711 .

\footnotetext{
${ }^{258}$ FIORAVANTE, Fernanda "Às custas do sangue, fazenda e escravos": formas de enriquecimento e padrão de ocupação dos ofícios da Câmara de Vila Rica, c. 1711 - c. 1736. Rio de Janeiro: UFRJ, PPGHIS, 2008.

${ }^{259}$ AHU, Cons. Ultra. - Brasil/MG, cx. 16, doc. 79. CARTA de D. Lourenço de Almeida, governador de Minas, para D. João $\mathrm{V}$, informando sobre o decorrer das obras de construção de quartéis das Companhias de Dragões e da recusa da nova Câmara deVila Rica em custear as despesas. 08/05/1730.

${ }^{260}$ ROMEIRO, Adriana; BOTELHO, Angela Vianna. Dicionário histórico das Minas Gerais: período colonial. $2^{\underline{a}}$ edição revista. Belo Horizonte, MG: Autêntica, 2004, p.60.

${ }^{261}$ Ibdem.

${ }^{262}$ Ibdem.
} 
Durante sua administração, Castro retomou as discussões a cerca do quinto causando grande insatisfação na população das Minas ${ }^{263}$.

Logo que assumiu o governo da capitania, o Conde propôs a extinção das Casas de Fundição e a substituição do método de arrecadação do ouro pelo quinto para o sistema de capitação. Além disso, todas as pessoas que possuíssem escravos estariam obrigadas a pagar o tributo, independente da ocupação. Para evitar a fuga da população das Minas para atividades sem escravaria, André de Melo e Castro também ordenou que fosse cobrado o tributo sobre o lucro das pessoas que estivessem exercendo outras atividades. Essa medida provocou um novo ciclo de inquietação política nas Minas e foi o estopim para os motins do São Francisco em $1736^{264}$.

\footnotetext{
${ }^{263}$ FIORAVANTE, Fernanda "Às custas do sangue, fazenda e escravos": formas de enriquecimento e padrão de ocupação dos ofícios da Câmara de Vila Rica, c. 1711 - c. 1736. Rio de Janeiro: UFRJ, PPGHIS, 2008.

${ }^{264}$ Ibdem.
} 


\section{CAPÍTULO 3}

ENTRE CONFLITOS E MEDIAÇÕES - A ATIVIDADE CAMARÁRIA NAS MINAS 
O objetivo deste último capítulo é entender como ocorreu a instalação das câmaras nas Minas e o processo de estabelecimento do poder das municipalidades na região mineradora. Também pretendo discutir como a atividade camarária nas Minas era limitada pelo contexto social e político da região.

Conforme assinalei anteriormente, na década de 1710, as câmaras começaram a ser instaladas na área mineradora com o intuito de normatizar o cotidiano da região e estabelecer um espaço de mediação entre a Coroa e a população das Minas. Durante esse período as municipalidades na região mineradora passaram por uma fase de progressiva afirmação do poder dentro da sociedade local.

O alargamento do poder camarário nas Minas foi limitado pelo Estado português de diversas formas. Todavia, a Coroa lusa não foi a única a cercear o poder das câmaras na área mineradora. O próprio contexto social determinou os limites da atividade camarária nas Minas. A população, os oficiais régios e com o tempo as próprias municipalidades procuraram impor fronteiras para as ações políticas das câmaras nas Minas.

A introdução das municipalidades nas Minas gerou certo estranhamento por parte da população que, muitas vezes, ignorava a burocracia portuguesa que deveria organizar a vida dos súditos. Esse estranhamento à presença efetiva de instituições portuguesas na região mineradora causou, muitas vezes, conflitos violentos. Um exemplo disso é o motim do Morro Vermelho em 1715.

O conflito no Morro Vermelho denota a insatisfação da população de Vila Nova da Rainha em relação à decisão da junta geral das câmaras de 1714. Conforme destaquei no segundo capítulo deste trabalho, no Termo firmado entre as câmaras em 1713 ficou estipulado que a arrecadação do ouro diminuiria para 25 arrobas anuais e as rendas de passagem passariam das municipalidades para o Estado português. Entretanto, em 1714, o governador D. Brás Baltazar reuniu as câmaras das Minas novamente e solicitou que a arrecadação passasse a ser feita pelo sistema de quintos por bateias.

As municipalidades da região mineradora decidiram acatar ao pedido do governador e no ano posterior iniciaria a nova forma de cobrança. No entanto, em 1715, a população do Morro Vermelho, termo de Vila Nova da Rainha, amotinou-se exigindo que as Minas fossem 
isentas para sempre dessa forma de cobrança e que a arrecadação do ouro continuasse pelo método de fintas ${ }^{265}$. O governador não consentiu e as arruaças continuaram por Vila Nova da Rainha.

Temendo que o conflito se espalhasse para as vilas de Sabará, Vila Rica e Vila do Carmo, D. Brás Baltazar suspendeu a medida. Em carta ao provedor da Fazenda, Francisco de Távora, o governador lastimou a suspensão da medida e expressou os motivos que o levaram a revogar a forma de cobrança ${ }^{266}$ :

[...] sem embargo de todas as diligências que a este respeito não pode persuadir moradores a que aceitassem essa forma de cobrança; e como de persistir nela poderiam originar-se algumas inquietações muito contra o sossego deste governo, [suspendeu] a execução para não arriscar minas a última ruína.

Brás Baltazar optou por implantar as mudanças que constavam no termo de 1713 porque receava as reações negativas da população.

É interessante ressaltar que o pedido de Baltazar foi atendido pelas câmaras. A população, porém, não concordou com a mudança na forma de arrecadação do ouro e amotinou-se. A rebelião do Morro Vermelho de 1715 evidencia que as municipalidades na região mineradora sofreram com a resistência da população as suas ações políticas. A população das Minas limitava as ações das câmaras através das reações negativas e, em diversos momentos, violentas.

A própria constituição das câmaras nas Minas, muitas vezes, provocou a insatisfação na população porque o estabelecimento das municipalidades implicava em um maior controle do cotidiano e a instauração de novos impostos. Inclusive, era uma estratégia da Coroa implantar novas municipalidades no sertão da capitania para aumentar a arrecadação de tributos na região mineradora ${ }^{267}$. Durante a década de 1710, a iniciativa do Estado Português de elevar arraiais a categoria de vila provocou, muitas vezes, a sublevação da população nas Minas. Um exemplo disso é o motim de Rio das Velhas, de 1718.

Os revoltosos de Rio das Velhas reivindicavam que o arraial dos Papagaios não fosse elevado à condição de vila. A população não queria ser onerada com os impostos da Coroa

\footnotetext{
${ }^{265}$ APM, SG 4, fls 396-398. CARTA de D. Brás Baltazar, 28/03/1715.

${ }^{266}$ APM, SG 9, fl. 39-40. CARTA de D. Brás Baltazar para Francisco de Távora, 23/04/1715.

${ }^{267}$ ROMEIRO, Adriana; BOTELHO, Angela Vianna. Dicionário histórico das Minas Gerais: período colonial. $2^{\mathrm{a}}$ edição revista. Belo Horizonte, MG: Autêntica, 2004.
} 
portuguesa. Também os amotinados não queriam a ereção de uma câmara na localidade porque esta instituição cercearia as atividades ilegais da população e dos régulos da região.

Na Sedição de Vila Rica de 1720 a população também reivindicou medidas que iam contra atividade política da câmara local. Uma das reivindicações dos revoltosos era por fim aos abusos de poder, principalmente, dos oficiais da câmara Vilariquenha ${ }^{268}$. Mesmo tendo oficiais da municipalidade diretamente envolvidos no conflito, a câmara de Vila Rica foi alvo do descontentamento dos rebelados de 1720. Esse fato não foi destacado pela historiografia sobre o tema porque ora os historiadores enfatizam o caráter fiscal da Sedição de Vila Rica ${ }^{269}$, ora os historiadores se preocupam com a ação dos potentados locais e suas redes clientelares na revolta de $1720^{270}$.

A produção historiográfica sobre a Sedição de Vila Rica tem ignorado a importância da participação da população das Minas na rebelião de 1720. Os amotinados almejavam melhores condições de vida na região mineradora e a manutenção de seus costumes. No Termo, essas reivindicações da população de Vila Rica foram expressas ${ }^{271}$.

Outro ponto importante são as rebeliões contrárias às formas como as câmaras conduziam a administração das Minas. Conforme assinalei no primeiro capítulo, foram comuns na região mineradora os motins provocados pela falta de controle das municipalidades do abastecimento alimentar ou pela instauração de contratos para gêneros de primeira necessidade considerados abusivos. Por exemplo, em 1721 ocorreram dois motins, um em São João del- Rei e outro em Rio das Velhas, por causa da questão da implantação de

\footnotetext{
${ }^{268}$ TERMO que se fez sobre a proposta do povo de Vila Rica na ocasião em que veio amotinado a Vila do Carmo. In ANASTASIA, Carla Maria Junho. Vassalos Rebeldes: violência coletiva nas Minas na primeira metade do século XVIII. Belo Horizonte: C/Arte, 1998, p. 141-143.

${ }^{269}$ Sobre os estudos que enfatizam o caráter fiscal da Sedição de Vila Rica de 1720 conferir: CAMPOS, Maria Verônica. Governo de mineiros: "de como meter as Minas numa moenda e beber-lhe o caldo dourado" 1693 a 1737. São Paulo: USP, FFLCH, 2002. e ANASTASIA, Carla Maria Junho. Vassalos Rebeldes: violência coletiva nas Minas na primeira metade do século XVIII. Belo Horizonte: C/Arte, 1998. Também conferir: FONSECA, Alexandre Torres. A Revolta de Felipe dos Santos. In RESENDE, Maria Efigênia Lage de; VILlAlTA, Luiz Carlos (Coord.). História das Minas Gerais. As minas setecentistas. Belo Horizonte, MG: Autêntica, Companhia do Tempo, vol. 1, 2007.

${ }^{270}$ Sobre os trabalhos que destacam as redes clientelares envolvidas na rebelião de 1720 conferir: MATHIAS, Carlos Leonardo Kelmer. Jogos de interesses e redes clientelares na revolta mineira de Vila Rica (c. 1709 c. 1736). Rio de Janeiro: UFRJ, PPGHIS, 2005. E CASTRO, João Henrique Ferreira de. A repressão à Revolta de Vila Rica de 1720: Perdão e Punição sob a ótica da justiça no Império Ultramarino Português. Rio de Janeiro: UFRJ, PPGHIS, 2012.

${ }^{271}$ TERMO que se fez sobre a proposta do povo de Vila Rica na ocasião em que veio amotinado a Vila do Carmo. In ANASTASIA, op. cit., p. 141-143.
} 
contratos que envolviam gêneros importantes na dieta da população. Nestes casos, as rebeliões visavam impor limites à atuação política das municipalidades da região mineradora.

É necessário ressaltar que o poder das câmaras nas Minas nem sempre foi cerceado pela população através de revoltas. Em diversas ocasiões, o não cumprimento de normas estipuladas pelas municipalidades restringia o campo de ação política dos oficiais camarários. Por exemplo, no edital publicado em 1712 pela câmara Vilariquenha sobre a cobrança dos termos de aforamento dos moradores ${ }^{272}$, é perceptível que a medida foi publicada com o objetivo de relembrar a população de Vila Rica das suas obrigações com a municipalidade.

Segundo Maria Aparecida de Menezes Borrego ${ }^{273}$, antes da constituição das câmaras na região mineradora, não existiam oficiais responsáveis pelo ordenamento urbano. Isso significa que muitas medidas tomadas pelas municipalidades eram novas para a população e alteravam drasticamente o costume da região mineradora. $\mathrm{O}$ não pagamento das taxas de aforamento sugere que a população ou estranhava o novo imposto sobre o espaço urbano ou não reconhecia a necessidade de pagar às câmaras as taxas. Infelizmente, não é possível determinar o motivo que levava a população a não pagar os tributos às municipalidades, mas, de qualquer forma, a necessidade das câmaras em relembrar constantemente a população de suas obrigações com as municipalidades demonstra que o poder desta instituição não se estabeleceu de forma imediata.

Após a instauração das câmaras pela Coroa na década de 1710, as municipalidades tiveram que conquistar seu reconhecimento dentro da sociedade mineradora. Nas Minas, muitas vezes, o processo de efetivação do poder camarário foi marcado por rebeliões. Entretanto, a própria alteração do cotidiano da região mineradora dificultou o estabelecimento do poder das municipalidades nas Minas.

É importante ressaltar que a população das Minas não era um grupo homogêneo. A sociedade mineradora era composta por indivíduos com diferentes anseios e história. Para a elite mineradora a instalação das municipalidades, em diversas ocasiões, foi benéfica porque,

\footnotetext{
${ }^{272}$ Atas da Câmara Municipal de Ouro Preto (1711-1715). Anais da Biblioteca nacional. 1927. v. 49, p. 199-391, p. 230. TERMO de vereação que fizeram os oficiais da câmara em resolveram se não fizessem ranchos sem se aforarem.

${ }^{273}$ BORREGO, Maria Aparecida de Menezes. Códigos e práticas: o processo de constituição urbana em Vila Rica colonial (1702-1748). São Paulo: Annablume, 2004.
} 
além de conquistarem um espaço de negociação direta com a Coroa portuguesa, poderiam adquirir mercês e benesses através da atividade camarária.

Conforme destaquei anteriormente, os oficiais camarários estavam inseridos na sociedade do Antigo Regime e faziam parte da elite local. De acordo com Fernanda Fioravante $^{274}$, os eleitos para os cargos camarários em Vila Rica já tinham recebido suas mercês antes de se tornarem oficiais da câmara e raramente pleiteavam novas. A maioria dos camarários da municipalidade Vilariquenha possuía altas patentes nos terços de ordenança e auxiliares nas Minas $^{275}$. Portanto, os homens bons entravam para a câmara de Vila Rica porque era uma forma de confirmar o status quo dentro da sociedade do Antigo Regime. Além disso, os ocupantes dos cargos camarários utilizavam, muitas vezes, suas prerrogativas de oficiais para privilegiar as redes clientelares em que estavam inseridos. Um exemplo disso é a arrematação de contratos.

De acordo com Evaldo Cabral de Mello ${ }^{276}$, os contratos eram fundamentais para a manutenção das redes clientelísticas dos oficiais camarários porque a maioria era arrendada por particulares ligados aos homens bons que ocupavam os cargos nas municipalidades. Contudo, nas Minas, a manutenção das redes clientelares a partir das câmaras foi dificultada de forma indireta pela Coroa.

Segundo Maria Verônica Campos ${ }^{277}$, a perda sistemática de prerrogativas pelas câmaras, como a do estabelecimento de alguns contratos, dificultou a manutenção dessas redes clientelísticas. Desde a implantação das câmaras nas Minas, as municipalidades tiveram uma perda progressiva de rendas e o aumento de drástico de custos de manutenção. Por exemplo, na representação de 12 de julho de 1729 os oficiais camarários de Vila Rica solicitaram ao Rei um novo contrato para cadeia porque não conseguiam fazer a manutenção devida $^{278}$ :

\footnotetext{
${ }^{274}$ FIORAVANTE, Fernanda "Às custas do sangue, fazenda e escravos": formas de enriquecimento e padrão de ocupação dos ofícios da Câmara de Vila Rica, c. 1711 - c. 1736. Rio de Janeiro: UFRJ, PPGHIS, 2008.

${ }^{275}$ Ibdem.

${ }^{276}$ MELLO, Evaldo Cabral de. A fronda dos mazombos: nobres contra mascates, Pernambuco, 1666-1715. São Paulo: Editora 34, 2003, p. 78-79.

${ }^{277}$ CAMPOS, Maria Verônica. Governo de mineiros: "de como meter as Minas numa moenda e beber-lhe o caldo dourado 1693 a 1737. São Paulo: USP, FFLCH, 2002.

${ }^{278} \mathrm{AHU}$, Cons. Ultra. - Brasil/MG, cx. 14, doc. 46. REPRESENTAÇÃo dos oficiais da Câmara de Vila Rica a respeito das rendas de mais de três mil oitavas de ouro despendidas com os salários dos oficiais das
} 
[...] as câmaras desta capitania estão na posse de arrendar a carceragem dos seus distritos aplicando aquela importância para as despesas do bem comum em que esta câmara não só tem excedido todos os anos, mas também nos grandes gastos que fez e está fazendo em utilidade da Real Fazenda de Vossa Majestade.

A perda de prerrogativas pelas câmaras também gerou outros problemas como o aumento de funções dos oficiais régios. O trabalho dos oficiais que atuavam nas Minas em nome do Rei foi dificultado porque os oficiais acabavam acumulando funções. Por exemplo, em 1722, Francisco Rodrigues da Fonseca, provedor da fazenda, solicitou à Coroa o aumento dos seus emolumentos porque estava sobrecarregado na cobrança do ouro nas Minas ${ }^{279}$. Antes da instituição do cargo de provedor da fazenda, a arrecadação do ouro era responsabilidade dividida entre as câmaras e os ouvidores. Apesar de o oficial está pedindo aumento dos seus emolumentos, no mesmo documento, Rodrigues reclama da quantidade exorbitante de trabalho, porque era o único encarregado por realizar a cobrança em toda comarca ${ }^{280}$.

A ação política das câmaras também era cerceada pelos oficiais régios, principalmente, pelos governadores das Minas e ouvidores de comarca. Para Campos ${ }^{281}$, a instituição dos ouvidores nas municipalidades das Minas se configurou como a primeira medida tomada pela Coroa para restringir as prerrogativas e funções das câmaras porque os ouvidores tinham a responsabilidade de controlar a atividade camarária.

Mesmo com a responsabilidade de supervisionar as ações dos camarários, em muitas ocasiões, os ouvidores auxiliaram os oficiais das municipalidades em medidas que iam de encontro aos anseios do Estado português e da população das Minas. Por exemplo, no motim do Rio das Velhas de 1721, a câmara e o ouvidor tentaram impor um contrato de carnes, mesmo causando descontentamento na população da região.

Também é imprescindível destacar que as relações entre ouvidores e camarários foram, muitas vezes, conflituosas limitando de forma exarcebada as ações das municipalidades. A desavença entre o ouvidor Martinho Vieira e Pascoal da Silva Guimarães na Sedição de Vila Rica é um exemplo disso.

Casas de Fundição e Moeda e pedindo que não seja nomeado José Boaventura Vieira para carcereiro de Vila Rica. 12/07/1729.

${ }^{279}$ AHU, Cons. Ultra. - Brasil/MG, cx. 03, doc. 02. REQUERIMENTO de Francisco Rodrigues da Fonseca, procurador da Coroa e Fazenda Real do Ouro Preto, pedindo a D. João V a mercê de conceder duas libras de ouro por ano, em paga de seus serviços. 02/01/1722.

${ }^{280}$ Ibdem.

${ }^{281}$ CAMPOS, Maria Verônica. Governo de mineiros: “de como meter as Minas numa moenda e beber-lhe o caldo dourado 1693 a 1737. São Paulo: USP, FFLCH, 2002. 
Conforme assinalei anteriormente, Guimarães não possuía uma boa relação com Martinho Vieira. Segundo escritos coetâneos, Vieira tinha obstruído diversas ações de Guimarães no ano anterior à Sedição, quando Pascoal ocupava o cargo de juiz ordinário na câmara de Vila Rica ${ }^{282}$. Além disso, Pascoal da Silva Guimarães era próximo do ex-ouvidor da comarca, Manoel Mosqueira da Rosa. Portanto a substituição de Vieira por Mosqueira era conveniente para Guimarães porque facilitaria as ações de Pascoal na comarca de Ouro Preto.

Infelizmente, não é possível estipular um padrão nas relações entre camarários e ouvidores, mas, percebe-se que a relação entre os oficiais possuía um forte cunho personalista e isso influenciava na condução do interesses da Coroa lusa e dos povos.

O conflito entre as câmaras nas Minas também obstruiu as ações políticas das municipalidades na região. Segundo Joaquim Romero Magalhães ${ }^{283}$, antes da cobrança do ouro ser retirada das municipalidades das Minas, os embates em torno da jurisdição para realizar a arrecadação foram frequentes entre as câmaras da região. $O$ status das municipalidades dentro do aparelho político e administrativo português também gerou disputas entre as municipalidades nas Minas ao longo do século XVIII.

Conforme assinalei no segundo capítulo, a região mineradora possuía muitas câmaras próximas. Entretanto, dentro da administração portuguesa, essas municipalidades tinham diferentes status. Nas Minas, a concessão de privilégios para determinadas câmaras provocou conflitos entre os camarários. A municipalidade de Vila do Carmo, por exemplo, solicitou os privilégios da cidade do Porto e era onde os governadores alojavam-se no início dos Setecentos em caso de motins. No pedido, os oficias da municipalidade de Vila do Carmo $\operatorname{argumentam}^{284}$ :

Várias vezes tem os governadores destas Minas chamado as sua presença as câmaras delas,
para negócios do Real serviço de V. Mag. ${ }^{\text {de }}$ e concorrendo todas em Junta com os homens de
mais distinção deste governo, sempre tem havido dúvidas com a Câmara de Vila Rica, por
quererem seus oficiais preferir-nos nos lugares, e assentos. E sendo a Câmara de Vila Nossa
Senhora do Carmo a mais antiga e o estar na posse de ter o primeiro lugar, e como sempre teve
a fortuna de falhar primeiro, também a teve de mostrar primeiro o grande zelo com que seus

${ }^{282}$ DISCURSO histórico e político sobre a sublevação que nas Minas houve no ano de 1720. Belo Horizonte: Fundação João Pinheiro, 1994. (Estudo crítico de Laura de Mello e Souza).

${ }^{283}$ MAGALHÃES, Joaquim Romero. As Câmaras Municipais, a Coroa e a cobrança dos quintos do ouro nas Minas Gerais (1711-1750). In GONÇALVES, Andréia Lisly; CHAVES, Cláudia Maria das Graças; VENÂNCIO, Renato Pinto (Org.) Administrando Impérios: Portugal e Brasil nos Séculos XVIII e XIX. Belo Horizonte, MG: Fino Traço, 2012.

${ }^{284}$ AHU, Cons. Ultra., Brasil/MG, cx. 12, doc. 54. REPRESENTAÇÃo dos oficiais de Vila do Ribeirão do Carmo, a respeito dos privilégios de que as outras Câmaras gozavam e solicitando os mesmo privilégios para a referida Câmara, 21/07/1728. 
oficiais e o seu povo servem e tem servido a V. M. por que foi a primeira que abraçou o estabelecimento das casas de moeda e fundição, e a primeira que prometeu de donativo cento e vinte e cinco arrobas de ouro que pagam estas Minas por seis anos para suprimento dos gastos dos felicíssimos de suas altezas [...] além de ter sido a primeira em outros muitos serviços que se tem feito a V. Mag. ${ }^{\text {de }}$.

A câmara de Vila do Carmo auferiu o status de cabeça de comarca e os privilégios da municipalidade do Porto $^{285}$. Essa concessão não agradou aos camarários de Vila Rica que solicitaram os mesmos privilégios recebidos pela municipalidade de Vila do Carmo. Na representação, os oficiais camarários alegaram que a câmara Vilariquenha situava-se no centro mais populoso e economicamente ativo da capitania ${ }^{286}$. Contudo, a Coroa negou o pedido da municipalidade de Vila Rica.

Também é importante ressaltar que as municipalidades aproveitavam-se das reações contra o poder régio para alavancar seu status dentro da administração portuguesa. As câmaras nas Minas, muitas vezes, fizeram questão de se posicionar contra os motins encetados em outras municipalidades. Por exemplo, na Sedição de Vila Rica, a câmara de São João del-Rei enviou uma carta ao monarca exaltando a atitude de D. Pedro Miguel de Almeida na contenção do motim ${ }^{287}$ :

execranda revolução destes povos em que se devia temer esse delitos e conspiração contra o real domínio de V. Mag. ${ }^{\text {de }}$ passando a ser perturbadores do sossego público que até agora logrou felizmente este governo de zelosa atividade e boa administração de justiça do mesmo Conde de Assumar, nos parece por isso dar tão bem conta a V. Mag. ${ }^{\text {de }}$ da singular fidelidade com a nobreza desta Vila de São João del-Rei mostrou nesta ocasião que sabia mais que as outras deste governo a rigorosa obrigação que tem os bons vassalos de dar as vidas e o sangue na obediência do seu rei e senhor natural porque juntando-se todos uniformemente vieram a casa deste Senado e nela prometeram instantemente sem embargo da sublevação quase como dos outros povos queriam estar e obedecer a todas as leis e reais decretos de V. Mag. ${ }^{\text {de }}$, não só pela razão de bons vassalos mas para continuarem a firmeza em que esta vila se singularizou sempre que sendo a única em que até o presente momento não tem havido revoluções populares $[\ldots]$.

É interessante notar que a câmara de São João del-Rei reafirma no documento que a população sob sua jurisdição não é propensa a rebeliões. Percebe-se que o status das câmaras nas Minas estava ligado aos bons hábitos das populações governadas. Sugere-se que a estabilidade de uma determinada câmara estava atrelada a capacidade da municipalidade de

\footnotetext{
${ }^{285}$ AHU, Cons. Ultra., Brasil/MG, cx. 2, doc. 103. CONSULTA do Conselho Ultramarino sobre a representação da Câmara de Vila de Nossa Senhora do Carmo respeitante as dívidas da dita Câmara e sobre ser aquela cabeça de comarca, 11/02/1721.

${ }^{286}$ AHU, Cons. Ultra., Brasil/MG, cx. 3, doc. 74. REPRESENTAÇÃo dos oficiais da Câmara de Vila Rica pedindo privilégios da Câmara da cidade do Porto por haver já o exemplo da Câmara de São Paulo, 26/10/1722.

${ }^{287}$ AHU, Cons. Ultra., Brasil/MG, cx. 4, doc. 73. REPRESENTAÇÃo da Câmara de São João delRei,informando a $D$. Foão $V$ sobre a sublevação dos povos de Minas e sobre a lealdade e firmeza demonstradas pela nobreza da referida Vila, na defesa da autoridade régio, 02/08/1720.
} 
ser reconhecida como uma instituição pela população sob sua jurisdição. Entretanto, é notável que os camarários enalteciam ou depreciavam a imagem da população sob seu governo conforme a ocasião.

A má reputação dos vassalos das Minas também era utilizada pelos oficiais camarários para auferir maior margem de negociação com a Coroa. Essa utilização dúbia pelos oficiais das municipalidades estava relacionada com as estruturas de poder comuns ao Antigo Regime.

De acordo com Russel-Wood ${ }^{288}$, durante o Antigo Regime, o Rei não gozou de um poder total no ultramar. Existia uma dependência da periferia. O que ocorreu não só com o Rei, mas com os oficiais régios e câmaras, foi uma autoridade negociada. Entretanto, a negociação entre as partes ocorria de forma desigual, já que estamos tratando de um corpo social hierarquizado, uma sociedade do Antigo Regime. O tamanho dessa margem de negociação entre as partes dependia também de diversos fatores, tais como: a importância da localidade para Coroa, as formas de negociação empregadas pela parte solicitante e o imaginário sobre a região.

A tradição contestatória das Minas era um dos elementos que corroboraram, em diversas ocasiões, para o alargamento da margem de negociação entre a Coroa e as municipalidades das Minas. Segundo Laura de Mello Souza ${ }^{289}$, era comum por parte dos oficiais régios exaltarem o potencial contestatório da população da região mineradora como uma forma de valorizar seus governos e como uma estratégia para resguardar seus próprios interesses nas governações. Esse temor da Coroa em relação à população da região mineradora auxiliou os camarários porque, de certa forma, muitas medidas não foram instauradas na região mineradora devido ao receio dos oficiais régios e do Estado português em desencadear motins. Essa concepção está presente nos pareceres enviados pelas autoridades do ultramar a Coroa lusa, nos escritos coevos e nas argumentações das representações dos oficiais das Minas.

\footnotetext{
${ }^{288}$ RUSSEL-WOOD, A. J. R. Centros e periferias no Mundo Luso-Brasileiro - 1500-1808. In: Revista Brasileira de História, v. 18, n. 36, São Paulo, 1998. Nesse texto, o autor utiliza o conceito de autoridade negociada desenvolvido por Jack P. Greene para questionar a historiografia sobre a administração no período colonial nos impérios hispânico e luso na América. Veja-se, também: GREENE, Jack P. Negotiated Authorities: Essays in Colonial Political ans Constitucional History. Charlottesville, University Press of Virginia, 1994.

${ }^{289}$ SOUZA, Laura de Mello e. O sol e a sombra: política e administração na América portuguesa do século XVIII. São Paulo: Companhia das Letras, 2006
} 
Conforme assinalei no primeiro capítulo, essa imagem negativa da população das Minas também está atrelada a uma noção moral e ética sobre as populações de áreas de extração de metais. Os pensadores portugueses do século XVII afirmavam em seus escritos que a regiões de produção de riquezas minerais levavam seus habitantes a cometerem delitos e pecados. Segundo Francisco Eduardo de Andrade $^{290}$, essa concepção ajudou para a construção de uma imagem negativa dos povos das Minas dentro do Estado Português. No Discurso, D. Pedro Miguel de Almeida ressaltou ${ }^{291}$ :

Eu contudo, reparando com mais atenção na antiga e continuada sucessão de perturbações que nelas se vêem, acrescentarei que a terra parece que evapora tumultos; a água escala motins; o ouro toca desaforos; destilam liberdades os ares; vomitam insolências as nuvens; influem desordem os astros; o clima é tumba da paz e berço da rebelião; a natureza anda inquieta consigo, e amotinada lá por dentro, é como no inferno.

Apesar de o documento tratar de um período de grande conturbação nas Minas, o trecho denota que o governador não fala apenas de acordo com sua experiência no governo da região mineradora. Há também um elemento de ordem moral na fala do Conde, comum a sociedade do Antigo Regime.

A forma de ocupação da região também era um elemento utilizado pelos oficiais para desqualificar o povo das Minas e reforçar a imagem negativa da população. D. Pedro Miguel de Almeida, em seu discurso de posse da capitania, em 1717, destacou que os perdões concedidos pelo monarca no início do século XVIII aos primeiros habitantes das Minas colaboraram também para a instabilidade social na região mineradora:

[...] veja-se o perdão geral, que el-Rei D. Pedro, de gloriosa memória antes de feitos os serviços já remunerados concedeu na primeira abertura das Minas, perdoando todos os crimes até ali cometidos; mas nisto talvez se poderá entender que o interesse do mesmo rei obraria mais que a sua magnanimidade; mas da segunda anistia o que diremos? Depois daquele tempo, ó deplorável tempo! Ó tempo de desgraças e de misérias! Em que a boca de qualquer das vossas armas vomitava uma violência, uma atrocidade, um assassino, um homicida.

Essa imagem negativa sobre a população das Minas contribuiu para o sucesso dos camarários das Minas em muitas negociações políticas. Para a Coroa, era melhor reconhecer, temporariamente, que suas intenções estavam erradas e aceitar as proposições das municipalidades, do que ter seu poder ameaçado por povos propensos a sublevações. No entanto, o sucesso dos oficiais camarários em muitas negociações não pode ser reduzido ao

\footnotetext{
${ }^{290}$ ANDRADE, Francisco Eduardo de. A invenção das Minas Gerais: empresas, descobrimentos e entradas nos sertões do ouro da América portuguesas. $1^{a}$ ed. Belo Horizonte, MG: Autêntica Editora/ Editora PUC Minas, 2008.

${ }^{291}$ DISCURSO histórico e político sobre a sublevação que nas Minas houve no ano de 1720. Belo Horizonte: Fundação João Pinheiro, 1994. (Estudo crítico de Laura de Mello e Souza), p.59.
} 
receio que a Coroa tinha de ter seu poder contestado nas Minas. A própria lógica social do Antigo Regime contribuiu para o aumento das margens de negociação entre o Rei e os oficiais das câmaras da região mineradora.

Como já foi exaustivamente discutido na historiografia de Portugal Moderno, a sociedade do Antigo Regime era dividida em corpos, ou seja, uma sociedade corporativa ${ }^{292}$. Uma pessoa não era considerada na sua individualidade, mas sim, dentro de uma determinada parte do corpo. O rei era a cabeça de toda a sociedade e difundia seu poder através da nobreza $^{293}$. Tanto o monarca, quanto os camarários das Minas, estavam imbuídos das lógicas da sociedade do Antigo Regime ao negociar mudanças e a manutenção do status quo na região mineradora.

É importante ressaltar que, era importante para o monarca fazer concessões às câmaras coloniais porque as municipalidades eram espaços de fortalecimento do poder do Rei na colônia. No ultramar, as municipalidades tinham a incumbência de difundir o poder do Rei através da manutenção do poder simbólico do monarca. As funções atribuídas às câmaras, como a promoção de festas e a assistência filantrópica, reforçavam a presença da Coroa portuguesa no ultramar. Ao não implantar medidas que geravam o descontentamento da população nas Minas, o monarca demonstrava aos oficiais camarários um dos atributos mais caros aos governantes do Antigo Regime: a magnanimidade ${ }^{294}$.

Após analisar as relações políticas que as municipalidades da região mineradora nutriam com as outras partes da sociedade do Antigo Regime, é notável que o poder desta instituição não se estabeleceu de forma imediata e intransigente nas Minas. Ao contrário, as ações políticas e as funções das municipalidades na região foram, em diversas ocasiões, adaptadas ao cotidiano devido às necessidades peculiares da área mineradora e a conjuntura política das Minas. É perceptível também que o Estado Português não foi o único a limitar o estabelecimento do poder das municipalidades nas Minas. A população, os oficiais régios, as câmaras e o contexto social e político da região mineradora trataram de restringir o campo de

\footnotetext{
${ }^{292}$ HESPANHA, Antonio Manuel. Panorama histórico da cultura jurídica européia. Lisboa: Europa-América, 1998.

${ }^{293}$ Ibdem.

${ }^{294}$ BICALHO, Maria Fernanda Baptista. A cidade e o império: o Rio de Janeiro no século XVIII. Rio de Janeiro: Civilização Brasileira, 2003.
} 
ação política das municipalidades nas Minas, ora através da violência, ora através da negociação política. 
CONCLUSÃO 
Ao longo desta dissertação procurei retratar como ocorreu a formação da Câmara de Vila Rica e se estabeleceu o poder das municipalidades na região mineradora. No primeiro capítulo, promovi um debate historiográfico sobre como ocorreu à ocupação das Minas e o Levante dos Emboabas. Ao tratar dos primeiros anos da mineração na área central da América lusa, busquei evidenciar como foi difícil o cotidiano na área de prospecção do ouro, devido à falta de infra-estrutura para receber o grande afluxo de pessoas, que atenderam ao chamado do metal. Também mostrei como os conflitos entre forasteiros e paulistas obstruíram a implantação das estruturas do Estado português nas Minas no início dos Setecentos. Logo após o Levante, abordei como o fim do conflito possibilitou o início do processo de instalação das estruturas políticas e administrativas da Coroa lusa na região.

O primeiro capítulo foi de suma importância para a dissertação porque evidenciou como a cultura política de contestação das Minas, notável ao longo do século XVIII, está enraizada na origem da capitania. A influência dos paulistas para a constituição de uma tradição de contestação ao poder régio foi presente na vida política da região mineradora. Também o caráter imediatista das medidas políticas e administrativas da Coroa lusa corroborou para o acaloramento dos ânimos nas Minas no início do século XVIII.

No segundo capítulo, procurei evidenciar, através da historiografia, as principais características das câmaras nas Minas e como as municipalidades deram prosseguimento à instalação do aparelho burocrático português na região. A instituição das câmaras nas Minas não foi marcada apenas por momentos de calmaria. O poder das municipalidades, ao contrário, estabeleceu-se na base do enfrentamento das múltiplas forças políticas presentes nas Minas.

Outro ponto importante dessa parte do trabalho é a análise sobre a atividade camarária dos oficiais da municipalidade Vilariquenha na primeira metade do XVIII. Apesar dos camaristas de Vila Rica terem participado da Sedição de 1720, a postura da câmara era de sempre tentar negociar com a Coroa as medidas para região mineradora a fim de amenizar os impactos negativos na região sob sua jurisdição. A maioria das negociações que a câmara de Vila Rica impetrou ao Estado português no período estudado objetivava a manutenção do status quo ou adaptação das medidas ao contexto social e político das Minas. 
No terceiro e último capítulo, busquei mostrar como as municipalidades da região mineradora tiveram progressivamente suas funções cerceadas pelos atores políticos durante o processo de estabelecimento do poder das câmaras nas Minas. A Coroa não foi a única a impor limites às municipalidades. Diversas sublevações ocorreram na região mineradora com o claro objetivo de coibir atitudes das municipalidades tidas como abusivas. $O$ não reconhecimento das ações políticas das câmaras pela população também pode ser considerada como uma forma de resistência pacífica a instauração do poder das municipalidades. Entretanto, não é possível afirmar se essa resistência foi exercida de forma premeditada.

Outro fator que corroborou para a restrição do poder das municipalidades nas Minas foi a composição das câmaras e a ocupação dos cargos régios na área mineradora. Muitas vezes, as municipalidades se desviaram de suas funções porque os oficiais camarários possuíam sua própria história e anseios que influenciavam no exercício da atividade camarária. Além disso, as relações de cunho personalista presentes nas diversas camadas da sociedade mineradora contribuíram para a forma como se dava a condução dos interesses da Coroa e da população dentro das municipalidades.

Quanto à margem de negociação dentro das estruturas políticas e administrativas do Estado português, é fundamental destacar que, apesar deste mecanismo existir, os oficiais camarários tiveram que se esforçar para se utilizar dessa prerrogativa. As negociações promovidas pelas municipalidades tinham como base a realidade em que viviam, ou seja, a realidade do Antigo Regime. Todavia, a negociação camarária não pode ser reduzida as lógicas da sociedade do Império português. O contexto social e político das Minas foi fortemente considerados nas proposições dos camarários das Minas ao Estado português e influenciou drasticamente nas medidas políticas tomadas para o governo das Minas. 
FONTES E REFERÊNCIAS BIBLIOGRÁFICAS 


\section{FONTES}

\section{Documentação manuscrita}

Projeto Resgate

AHU, Cons. Ultra. - Brasil/ MG, cx. 03, doc. 64. REPRESENTAÇÃO dos oficiais da Câmara de Vila Rica sobre o pagamento dos aluguéis das casas em que se acha o quartel dos oficiais e soldados dos Dragões e pedindo ordem para resolver o problema. $21 / 10 / 1722$.

AHU, Cons. Ultra. - Brasil/MG, cx. 03, doc. 02. REQUERIMENTO de Francisco Rodrigues da Fonseca, procurador da Coroa e Fazenda Real do Ouro Preto, pedindo a D. João V a mercê de conceder duas libras de ouro por ano, em paga de seus serviços. 02/01/1722.

AHU, Cons. Ultra. - Brasil/MG, cx. 14, doc. 46. REPRESENTAÇÃO dos oficiais da Câmara de Vila Rica a respeito das rendas de mais de três mil oitavas de ouro despendidas com os salários dos oficiais das Casas de Fundição e Moeda e pedindo que não seja nomeado José Boaventura Vieira para carcereiro de Vila Rica. 12/07/1729.

AHU, Cons. Ultra. - Brasil/MG, cx. 16, doc. 79. CARTA de D. Lourenço de Almeida, governador de Minas, para D. João $\mathrm{V}$, informando sobre o decorrer das obras de construção de quartéis das Companhias de Dragões e da recusa da nova Câmara deVila Rica em custear as despesas. 08/05/1730.

AHU, Cons. Ultra. Brasil/RJ, doc. 3214. CARTA de Borba Gato ao governador da capitania D. Fernando Martins Mascarenhas de Lencastre.

AHU, Cons. Ultra., Brasil/MG, cx. 12, doc. 54. REPRESENTAÇÃO dos oficiais de Vila do Ribeirão do Carmo, a respeito dos privilégios de que as outras Câmaras gozavam e solicitando os mesmo privilégios para a referida Câmara, 21/07/1728.

AHU, Cons. Ultra., Brasil/MG, cx. 2, doc. 103. CONSULTA do Conselho Ultramarino sobre a representação da Câmara de Vila de Nossa Senhora do Carmo respeitante as dívidas da dita Câmara e sobre ser aquela cabeça de comarca, 11/02/1721.

AHU, Cons. Ultra., Brasil/MG, cx. 2, doc. 103. CONSULTA do Conselho Ultramarino sobre a representação da Câmara de Vila de Nossa Senhora do Carmo respeitante as dívidas da dita Câmara e sobre ser aquela cabeça de comarca, 11/02/1721.

AHU, Cons. Ultra., Brasil/MG, cx. 4, doc. 73. REPRESENTAÇÃo da Câmara de São João delRei,informando a $D$. Foão $V$ sobre a sublevação dos povos de Minas e sobre a lealdade e firmeza demonstradas pela nobreza da referida Vila, na defesa da autoridade régio, 02/08/1720.

Arquivo Público Mineiro

APM, CMOP, cód. 12. Relação de Receita e despesa de Vila Rica. 1721-1723.

APM, CMOP, cód. 21. Relação de Receita e despesa de Vila Rica. 1725-1729. 
APM, CMOP, cód. 34. Relação de Receita e despesa de Vila Rica. 1734-1740.

APM, SC 06, fls. 37-37v. TERMO sobre a repartição das trinta arrobas. 7/12/1713.

APM, SC 06, fls. 80-81. TERMO do ajuste que se fez com os procuradores das câmaras e povos destas Minas a respeito dos quintos do ano de 1719.

APM, SC 12, fls. 21-21v. PROVISÃO passada a Silvestre Marques da Cunha, 24/11/1717.

APM, SG 4, fls 396-398. CARTA de D. Brás Baltazar, 28/03/1715.

APM, SG 9, fl. 39-40. CARTA de D. Brás Baltazar para Francisco de Távora, 23/04/1715.

Documentação impressa

ANTONIL, Andre João. Cultura e Opulência do Brasil por suas Drogas e Minas. São Paulo: Companhia Editora Nacional, 1967.

CARTAS do Conde de Assumar ao Rei de Portugal. Revista do Arquivo Público Mineiro. v. 3, 1898, p. 261266.

CÓDICE Costa Matoso. Belo Horizonte: Fundação João Pinheiro, vol. 1 e 2, 1999. Coordenação-geral de Luciano Raposo de Almeida Figueiredo e Maria Verônica Campos.

COLEÇÃO sumária das próprias leis, cartas régias, avisos e ordens que se acham nos livros da Secretaria do Governo desta capitania de Minas Gerais. Revista do Arquivo Público Mineiro. Belo Horizonte, MG: Imprensa Oficial das Minas Gerais, Ano XVI, 1911.

DIÁRIO da jornada que fez o Exmo. Senhor D. Pedro desde o Rio de Janeiro até a cidade de São Paulo, e desta até as Minas. Ano de 1717. Revista do Serviço do Patrimônio Histórico e Artístico Nacional, Rio de Janeiro, v. 3, 1939, p. 302.

DISCURSO histórico e político sobre a sublevação que nas Minas houve no ano de 1720. Belo Horizonte: Fundação João Pinheiro, 1994. Estudo crítico de Laura de Mello e Souza.

TERMO que se fez sobre a proposta do povo de Vila Rica na ocasião em que veio amotinado a Vila do Carmo. In ANASTASIA, Carla Maria Junho. Vassalos Rebeldes: violência coletiva nas Minas na primeira metade do século XVIII. Belo Horizonte: C/Arte, 1998, p. 141-143.

TRANSCRIÇÃO da primeira parte do Códice 23 - Seção Colonial. Registro de Alvarás, cartas e ordens régias e cartas do Governador ao Rei, 1721-1731. Revista do Arquivo Público Mineiro. Ano XXX, 1979, p. $117-278$.

TRANSCRIÇÃO da segunda parte do Códice 23 - Seção Colonial. Registro de alvarás, cartas, ordens régias e cartas do governador ao Rei, 1721-1731. Revista do Arquivo Público Mineiro, Belo Horizonte, Ano XXXI, 198. 


\section{REFERÊNCIAS BIBLIOGRÁFICAS}

ANASTASIA, Carla Maria Junho. Vassalos Rebeldes: violência coletiva nas Minas na primeira metade do século XVIII. Belo Horizonte: C/Arte, 1998.

ANDRADE, Francisco Eduardo de. A invenção das Minas Gerais: empresas, descobrimentos e entradas nos sertões do ouro da América portuguesas. $1^{\mathrm{a}}$ ed. Belo Horizonte, MG: Autêntica Editora/ Editora PUC Minas, 2008.

Bethencourt, Francisco. A América Portuguesa. In CHAUDHURI, K.. História da Expansão Portuguesa. Vol. 3. Lisboa: Temas e Debates, 1998.

BICALHO, Maria Fernanda Baptista. As Câmaras Municipais no Império Português: o exemplo do Rio de Janeiro. Revista Brasileira de História, São Paulo, v. 18, n.36, p. 251-280, 1998. Disponível em:

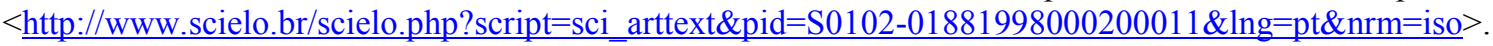

Acesso em: 26 de nov. de 2013.

$\overline{\text { Brasileira, 2003. }}$

A cidade e o império: o Rio de Janeiro no século XVIII. Rio de Janeiro: Civilização

BICALHO, Maria Fernanda Baptista; FRAGOSO, João e GOUVÊA, M. de Fátima. Uma leitura do Brasil Colonial. Bases da materialidade e da governabilidade no Império. In Penélope, nº 23, 2000.

BLUTEAU, Raphael. Vocabulario Portuguez \& latino: Aulico, Anatomico, Architectonico, Bellico, Botânico. Coimbra: Collegio das Artes da Companhia de Jesus, 1712 - 1728. Disponível em: $<$ http://www.brasiliana.usp.br/dicionario/edicao/1 > . Acesso em: 26 de nov. de 2013.

BORREGO, Maria Aparecida de Menezes. Códigos e práticas : o processo de constituição urbana em Vila Rica colonial (1702-1748). São Paulo: Annablume, 2004.

CALAFATE, Pedro (dir.). História do pensamento filosófico português. Vol. 2. Lisboa: Caminho, 1999

CAMPOS, Maria Verônica. Governo de mineiros: "de como meter as Minas numa moenda e beber-lhe o caldo dourado" 1693 a 1737. São Paulo: USP, FFLCH, 2002.

CARDOSO, Ciro Flamarion. História e Poder: uma nova história política? In CARDOSO, Ciro Flamarion; VAINFAS, Ronaldo (Org.). Novos domínios da História. 1. ed. Rio de Janeiro: Campus-Elsevier, 2011.

CASTRO, Hebe. História Social. In CARDOSO, Ciro Flamarion; VAINFAS, Ronaldo (Org.). Domínios da historia: Ensaios de teoria e metodologia. Rio de janeiro: Campus, 1997.

CASTRO, João Henrique Ferreira de. A repressão à Revolta de Vila Rica de 1720: Perdão e Punição sob a ótica da justiça no Império Ultramarino Português. Rio de Janeiro: UFRJ, PPGHIS, 2012.

CHAVES, Cláudia Maria das Graças. Perfeitos negociantes: mercadores das minas setecentistas. São Paulo: Annablume, 1999.

COSENTINO, Francisco Carlos. Governadores Gerais do Estado do Brasil: (XVI-XVII) ofícios, regimentos, governação e trajetórias. São Paulo: Annablume, 2009. 
ENNES, Ernesto José Bizarro. As guerras nos Palmares: (subsídios para a sua história). São Paulo: Companhia Editora Nacional, 1938.

FALCÓN, Francisco. História e Poder. In CARDOSO, Ciro Flamarion S; VAINFAS, Ronaldo (Coord). Dominios da historia: Ensaios de teoria e metodologia. Rio de Janeiro: Campus, 1997.

FIGUEIREDO, Luciano. Rebeliões no Brasil Colônia. Rio de Janeiro: Jorge Zahar, 2005.

Revoltas, fiscalidade e identidade colonial na América Portuguesa, 1640-1761. São Paulo:

USP, 1996.

Tradições Radicais: aspectos da cultura política mineira setecentista. In RESENDE, Maria Efigênia Lage de; VILLALTA, Luiz Carlos (Coord.). História das Minas Gerais. As minas setecentistas. Belo Horizonte, MG: Autêntica, Companhia do Tempo, vol. 1, 2007.

FIORAVANTE, Fernanda “Às custas do sangue, fazenda e escravos": formas de enriquecimento e padrão de ocupação dos ofícios da Câmara de Vila Rica, c. 1711 - c. 1736. Rio de Janeiro: UFRJ, PPGHIS, 2008.

FONSECA, Alexandre Torres. A Revolta de Felipe dos Santos. In RESENDE, Maria Efigênia Lage de; VILlALTA, Luiz Carlos (Coord.). História das Minas Gerais. As minas setecentistas. Belo Horizonte, MG: Autêntica, Companhia do Tempo, vol. 1, 2007.

FONSECA, Cláudia Damasceno. Arraiais e vilas d'el rei: espaço e poder nas Minas setecentistas. Belo Horizonte: Editora UFMG, 2011.

FURTADO, João Pinto. "Viva o rei, viva o povo, e morra o governador": tensão política e práticas de governo nas Minas Setecentistas. In BICALHO, Maria Fernanda Baptista; FERLINI, Vera Lúcia Amaral (Coord.). Modos de governar: idéias e práticas políticas no Império português, séculos XVI-XIX. São Paulo: Alameda, 2005.

FURTADO, Júnia. Homens de Negócio: A Interiorização da Metrópole e do Comércio nas Minas Setecentistas. São Paulo: Hucitec, 1999.

GOMES, Ângela de Castro. História, historiografia e cultura política no Brasil: algumas reflexões. In: SOIHET, Rachel e outras (org.). Cultura política: ensaios de história cultural, história política e ensino de história. Rio de Janeiro: Faperj/Mauad, 2005.

GOUVÊA, Maria de Fátima da Silva. Dos poderes de Vila Rica do Ouro Preto: notas preliminares sobre a organização político-administrativa na primeira metade do século XVIII. Revista Varia História, Belo Horizonte, $\quad \mathrm{n}^{\mathrm{o}} \quad 31, \quad$ p. 120-140, Jan/Jun 2004. Disponível em: $<$ http://www.fafich.ufmg.br/varia/admin/pdfs/31p120.pdf $>$. Acesso em: 4 de set. de 2014.

GREENE, Jack P. Negotiated Authorities: Essays in Colonial Political and Constitucional History. Charlottesville: University Press of Virginia, 1994.

HESPANHA, Antonio Manuel; XAVIER, Ângela Barreto. As Redes Clientelares. In MATTOSO, José (Org.). História de Portugal. Vol. 4. Lisboa: Estampa, 1998.

HESPANHA, Antonio Manuel. As vésperas do Leviathan. Instituições e poder político. Portugal. Séc. XVII. Coimbra: Livraria Almedina, 1994. 
Panorama histórico da cultura jurídica européia. Lisboa: Europa-América, 1998.

KIRSCHNER, Tereza Cristina. A reflexão conceitual na prática historiográfica. In: Textos de História. Dossiê A escrita da história: os desafios da multidisciplinaridade. Brasília, DF: UnB, v. 15, n 1/2, 2007.

LADURIE, Emmanuel Le Roy. Estado monárquico: França, 1460-1610. São Paulo: Companhia das Letras, 1994.

MAGAlHÃES, Joaquim Romero. As Câmaras Municipais, a Coroa e a cobrança dos quintos do ouro nas Minas Gerais (1711-1750). In GONÇALVES, Andréia Lisly; CHAVES, Cláudia Maria das Graças;

MATHIAS, Carlos Leonardo Kelmer. Jogos de interesses e redes clientelares na revolta mineira de Vila Rica (c. 1709 - c. 1736). Rio de Janeiro: UFRJ, PPGHIS, 2005.

MELLO, Evaldo Cabral de. A fronda dos mazombos: nobres contra mascates, Pernambuco, 1666-1715. São Paulo: Editora 34, 2003.

MENDONÇA, Sônia Regina de; FONTES, Virgínia. História e Teoria Política. In CARDOSO, Ciro Flamarion; VAINFAS, Ronaldo (Org.). Novos domínios da História. 1. ed. Rio de Janeiro: Campus-Elsevier, 2011.

NOVAIS, Fernando A. Portugal e Brasil na crise do antigo sistema colonial: (1777-1808). 8. ed. São Paulo: Hucitec 2005.

PAULA, João Antônio de Paula. A mineração de Ouro em Minas Gerais no século XVIII. In RESENDE, Maria Efigênia Lage de; VILlALTA, Luiz Carlos (Coord.). História das Minas Gerais. As minas setecentistas. Vol. 1. Belo Horizonte, MG: Autêntica, Companhia do Tempo, 2007.

PEREIRA, Marcos Aurélio de Paula. Vivendo Entre Cafres: Vida e Política do Conde de Assumar no Ultramar, 1688-1756. Niterói: UFF, ICHF, 2009.

PINTO, Virgilio Noya. O ouro brasileiro e o comércio anglo-português: uma contribuição aos estudos da economia atlântica no século XVIII. São Paulo: Companhia Editora Nacional, 1979.

ROMEIRO, Adriana; BOTELHO, Angela Vianna. Dicionário histórico das Minas Gerais: período colonial. $2^{\mathrm{a}}$ edição revista. Belo Horizonte, MG: Autêntica, 2004.

ROMEIRO, Adriana. A Guerra dos emboabas: novas abordagens e interpretações. In RESENDE, Maria Efigênia Lage de; VILLALTA, Luiz Carlos (Coord.). História das Minas Gerais. As minas setecentistas. Belo Horizonte, MG: Autêntica, Companhia do Tempo, vol. 1, 2007.

Paulistas e emboabas no coração das Minas: idéias, práticas e imaginário político no século XVIII. Belo Horizonte, MG: Editora UFMG, 2008.

Revisitando a Guerra dos Emboabas: práticas políticas e imaginário nas Minas setecentistas In BICALHO, Maria Fernanda Baptista; FERLINI, Vera Lúcia Amaral (Coord.). Modos de governar: idéias e práticas políticas no Império português, séculos XVI-XIX. São Paulo: Alameda, 2005.

RUSSEL-WOOD, A. J. R. A base moral e ética do governo local no Atlântico luso-brasileiro durante o Antigo Regime. In GONÇALVES, Andréia Lisly; CHAVES, Cláudia Maria das Graças; VENÂNCIO, Renato 
Pinto (Org.) Administrando Impérios: Portugal e Brasil nos Séculos XVIII e XIX. Belo Horizonte, MG: Fino Traço, 2012.

Centros e periferias no Mundo Luso-Brasileiro - 1500-1808. In: Revista Brasileira de História, v. 18, n. 36, São Paulo, 1998.

Identidade, etnia e autoridade nas Minas Gerais do século XVIII: leituras do Códice Costa Matoso. in: Varia História, Belo Horizonte, n. 21, julho de 1999, p. 100-118. Disponível em: $<$ http://www.fafich.ufmg.br/varia/admin/pdfs/21p100.pdf $>$. Acesso em: 5 de set. de 2014 .

SANTIAGO, Camila Fernanda Guimarães. Vila Ricas em festas: as festas promovidas pelo Senado da Câmara de Vila Rica (1711-1744). Belo Horizonte: UFMG, 2001.

SANTOS, Luís Cláudio Villafane G. Brasil ou Brasis? O dia em que adiaram o Carnaval. São Paulo: UNESP, 2010.

SILVA, Kalina Vanderlei. O miserável soldo \& a boa ordem da sociedade colonial: militarização e marginalidade na capitania de Pernambuco dos séculos XVII e XVIII. Recife: Prefeitura do Recife, Secretaria de Cultura, Fundação de Cultura Cidade do Recife, 2001.

SILVEIRA; Marco Antônio. Capitão-general, pai dos pobres: o exercício do governo na Capitania de Minas Gerais. In RESENDE, Maria Efigênia Lage de; VILLALTA, Luiz Carlos (Coord.). História das Minas Gerais. As minas setecentistas. Vol. 1. Belo Horizonte, MG: Autêntica, Companhia do Tempo, 2007.

SOUZA, Laura de Mello e; BICALHO, Fernanda. 1680-1720: O império deste mundo. São Paulo: Companhia das Letras, 2000.

SOUZA, Laura de Mello e. Desclassificados do ouro: A pobreza mineira do século XVIII. 3. ed. Rio de Janeiro: Graal, 1990.

UFMG, 1999.

Norma e conflito: aspectos da história de Minas no século XVIII. Belo Horizonte: Editora

O sol e a sombra: política e administração na América portuguesa do século XVIII. São Paulo: Companhia das Letras, 2006

VENÂNCIO, Renato Pinto (Org.) Administrando Impérios: Portugal e Brasil nos Séculos XVIII e XIX. Belo Horizonte, MG: Fino Traço, 2012.

WEBER, Max. Economia e sociedade: fundamentos da sociologia compreensiva. Vol. 1. 4ª ed. Brasília, DF: Editora Universidade de Brasília, 2012. 
